\title{
FEATURE 4/09 ON MÄSIARSKA ULICA IN KOŠICE AND ITS COLLECTION OF FINDS ${ }^{1}$
}

\author{
Marián Čurný - Lucia Luštíková - Rastislav Rusnák - Maroš Volovár
}

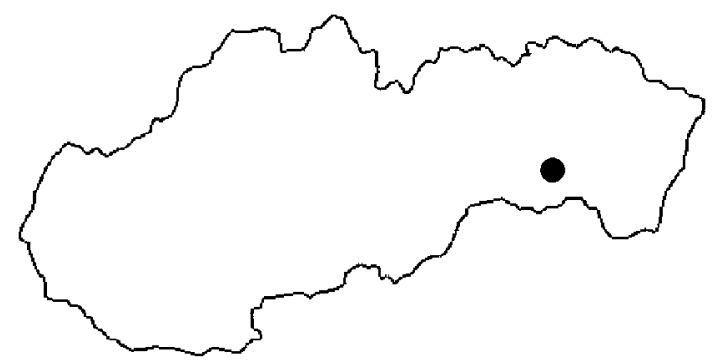

DOI: https://doi.org/10.31577/szausav.2020.67.8

Keywords: Slovakia, Košice, early modern period, waste pit, ceramics, glass

This study is primarily focused on an analysis of a collection of finds from the $16^{\text {th }}$ and $17^{\text {th }}$ century which originate from a single site. The collection, which consists mainly of ceramic and glass vessels, deserves individual attention on the grounds of the range and state of preservation of the artefacts. Only through the presentation of such collections as a whole can we reach a fuller understanding of the issues of the material culture of the early modern period. The study will also examine the possible interpretations of the site on which the artefacts were found and attempt to connect the findings obtained through analysis of the artefacts with existing information about the arrangement and ownership relationships of the site within the general context of the economic, political and religious situation in Košice in the period of the $17^{\text {th }}$ century.

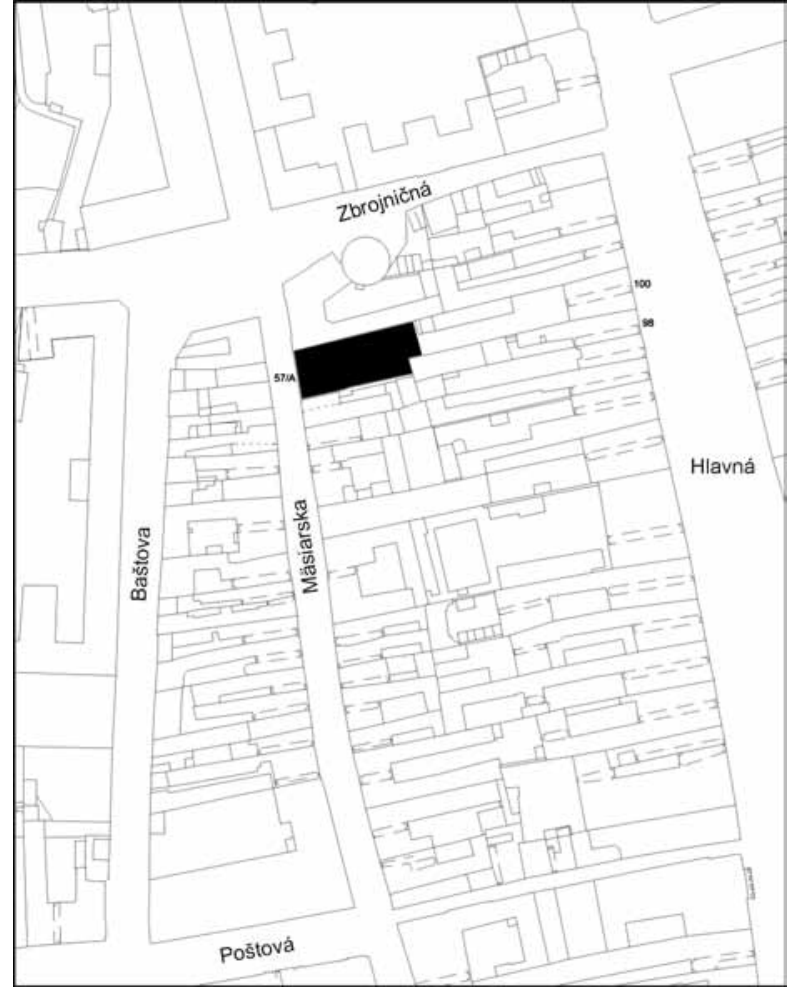

Fig. 1. Košice. Northwest section of the Old Town with highlighted boundaries of the surveyed parcel at Mäsiarska 57/A (in black) and also of the parcels at Hlavná 98 a Hlavná 100.
Between 2009 and 2010, the Institute of Archaeology of the Slovak Academy of Sciences carried out a two year archaeological investigation of a largely undeveloped urban residential plot at Mäsiarska 57/A in the historic centre of the city of Košice (Fig. 1). From the perspective of the modern day cadastral layout, the majority of the extensive surveyed area is identified as a single parcel of land. From a historical perspective, however, the land was probably composed of two deeper parcels, a likelihood which is confirmed by the remarkable width of the existing parcel, the arrangement of the plots within the context of the residential buildings and also by written sources dating from the early modern period.

The fourteen identified features and find sites belong to a wide range of occupational structures documenting the occupation of the site from the $13^{\text {th }}$ or $14^{\text {th }}$ centuries to the $19^{\text {th }}$ century. The nature of the identified occupancy from the $13^{\text {th }}$ and $14^{\text {th }}$ centuries suggests that the area of the plots leading back towards Mäsiarska Ulica formed sections of the rear courtyards of plots with houses facing Hlavná, the main street of the city, in this period. However, from the $15^{\text {th }}$ century at

\footnotetext{
1 This study was supported by VEGA Scientific Grant Agency Projects 1/0727/17 and 2/0084/18 and as a sustainability impact indicator of the project ITMS: 26220120059.
} 
the latest, the plot should be considered as having undergone a transformation in its property status together with its development as a separate entity. The main occupation period of the plot was from the end of the medieval period to the end of the $17^{\text {th }}$ century, at which point it again fell from separate occupational use. As is confirmed by written and cartographical sources, from the $18^{\text {th }}$ century the land was again connected to the house at Hlavná 100; the area of the plot served as a garden with landscaped features and continued in this state into the $19^{\text {th }}$ century (Fig. 2). The land remained vacant and unoccupied until 2010.

\section{AIMS AND OBJECTIVES}

Feature 4/09 was uncovered during the archaeological excavation of the plot of land at Mäsiarska 57/A in Košice, the results of which were published in 2014 (Rusnák 2014). The feature was, however, the only topic of the research which was not evaluated in the 2014 publication, instead being only mentioned briefly, on the grounds that the value of the collection of finds was exceptional within the context of the overall study and therefore deserved separate treatment. This remains the case, as does the need to present a comprehensive overview of the assemblage of finds from the feature, without which we will be unable to reach a fuller understanding of the issues of material culture in the early modern age, both within Košice and in a wider geographical context. It is also desirable to attempt to connect the indicated findings through the analysis of the collection with available information about the function of the site in from which they originate, their functional and spatial connections with other contemporary features on the site or with information about the ownership relationships to existing properties. Only in this way will it be possible to reach a level of wider and deeper analysis on the basis of a comparison of a greater variety of evaluated finds and at the very least to approach the discussion of trends which have long been in decline in international academic circles. The finds presented herein possess such a potential.

\section{DESCRIPTION AND INTERPRETATION OF THE FEATURE}

Feature 4/09 had the form of a pit of regular quadratic shape with sides of approximately $200 \mathrm{x}$ $150 \mathrm{~cm}$ and rounded corners. The find level was positioned at a depth of $170-180 \mathrm{~cm}$ below the modern-day surface. Initially, the feature could only be distinguished through the fact that its infill possessed a looser consistency than the surrounding soil, but this allowed its full ground plan to be determined. The bottom of the feature was located at a depth of $443 \mathrm{~cm}$ from the present day surface, i.e. $260-270 \mathrm{~cm}$ below the find level, with $140 \mathrm{~cm}$ of the infill recessed into a gravel subsoil. At the bottom of the feature, impressions in negative were found of post-like structures in the corners and also traces of panelling, possibly semi-circular timbering, of the walls between the corner posts (Fig. 3). The post in the southwest corner was of square shape, while the remaining three posts were round. While the feature originally had a wooden post structure in the corners, negative impressions of the timbered sides could only be identified on the lowest sections of the feature. It is possible to assume that this was the original structural arrangement of the whole feature if only on the basis of the stability of the 


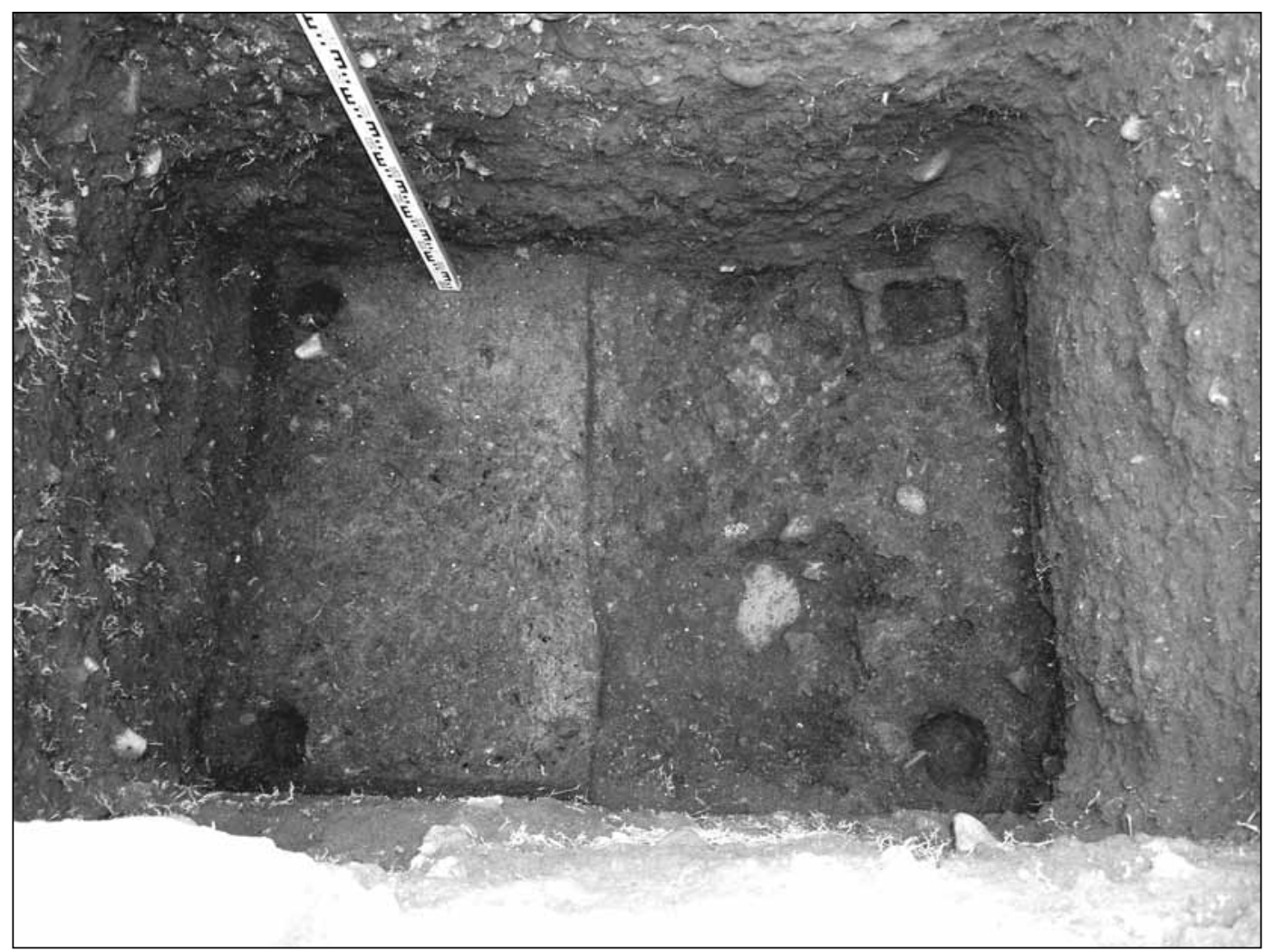

Fig. 3. Košice-Mäsiarska 57/A. Feature 4/09. Traces of the post structure in the corners of the feature and of wooden panelling between the corner posts at the base. Photo R. Rusnák.

feature. On both sides of the infill in the documented profile, perpendicular layers of sand were identified which are likely connected to the external insulation of the panel walls of the feature. No other structural elements of the feature could be determined. The infill of the feature consisted of layers with the characteristic downflow of the centre section accompanied by a slight shift in the downflow towards the northern side of the feature. The layers as a whole contained a significant number of finds. While the upper half of the feature was filled with a largely homogenous loose brown loam infill, the lower half was comprised of more layers. Loose grey and brown layers alternated with thinner reddish-brown burnt layers and clay-loam layers (Fig. 4).

The feature was initially identified as a cold store with a possible subsequent secondary use as a waste pit after it had ceased to serve its primary function. It should be noted, however, that we can find little in the archaeological sources which would support the first of these possibilities, with research favouring the second possibility; nonetheless, it is not possible to exclude the possibility of the first option entirely. In fact, the above-mentioned pattern of layering with a central downflow is more suggestive of the interpretation of the feature as a cesspit or waste pit (Frolík/Kozáková/Musil 2018, 457), even though the layers lack any specific faecal or organic character. The presence of a more aggressive environment is, however, indicated by the relative frequency of deformations to the glazes, painted decoration or even the surfaces of the ceramic artefacts in the form of various types of abrasion or other traces of non-violent deformation or wear. The artefacts of material culture found in the feature allow us to place it within the chronological framework of the early modern period. In addition to a smaller portion of the finds which are broadly dated to the end of the $15^{\text {th }}$ and beginning of the $16^{\text {th }}$ centuries, the overwhelming majority of the finds can be dated to the second half of the $17^{\text {th }}$ century. This period indeed saw the most intensive independent development of the site and is also the period for which we have the most archaeological and archival sources at our disposal.

The archaeological excavation carried out at Mäsiarska 57/A was unable to obtain any reliable details about the parcel boundaries in this period, therefore a closer determination of the feature within a specific contemporary parcel is relatively difficult although by no means impossible. Important clues are given, for example, by the horizontal stratigraphy with the indication of the continuation of 
the course of a particular alignment within the context of the spatial relationships of uncovered features from the late medieval and early modern periods. Coincidentally, this line in fact aligns well with the extension of the line of the parcel boundaries in terms of the wider relationships of the parcel block (Fig. 5). Establishing the spatial context of the feature within the parcel itself is somewhat more complicated and the relationship of the feature to any residential building is not entirely clear. Although its full extent and exact nature could not be determined as a whole from archaeological sources, it may nonetheless be possible to consider feature 10/09, a small recessed walled structure, as forming the core of a burgher house (Rusnák 2014, 327, 328).

\section{FEATURES INTERPRETED AS COLD STORES FROM KOŠICE}

Buried or sunken structures of various types and functions are found in the residential surroundings of urban plots. Some of these had a regular circular or quadrilateral floor plan, considerable depth and some form of reinforced walls, most commonly in the form of dry-laid stone or some type of wooden construction, and would therefore have been excavated and built to serve a longer term purpose rather than for some short term need. These structures were typically cesspits or waste pits which could be repeatedly emptied once full. Some of these structures have also been interpreted as cold stores or ice houses. Cold stores had a similar function as cellars, being used primarily for the storage of food, taking advantage of the prolonged lower temperatures below ground. This effect could be augmented further by adding ice to the pit and by insulating the access point. Providing that the cold store did not come to a sudden end, the structures could take on a new role after the loss of its primary use and be converted to a cesspit or waste pit, a circumstance which has contributed to the frequent ambiguities in the classification of these structures. Only rarely have archaeological investigations surveys been able to obtain relevant finds which would allow us to answer the key question of the classification of these structures. The find level of the feature no longer corresponds closely to the ground level at the time of its construction and there is little evidence relating to the insulation of the access or of any aboveground structure which would indicate the presence of latrine. Similarly lacking is archaeological evidence of the internal structural arrangement which would allow us to determine the ways in which food could have been stored and handled within the structure. Within Košice a relatively small number of structures of this type have been excavated and the results of the majority of these have not been published. There is therefore a lack of deeper insight into the spatial context of the arrangement of such structures within parcels of land on the basis of their function and their relationship to the main residential buildings. 


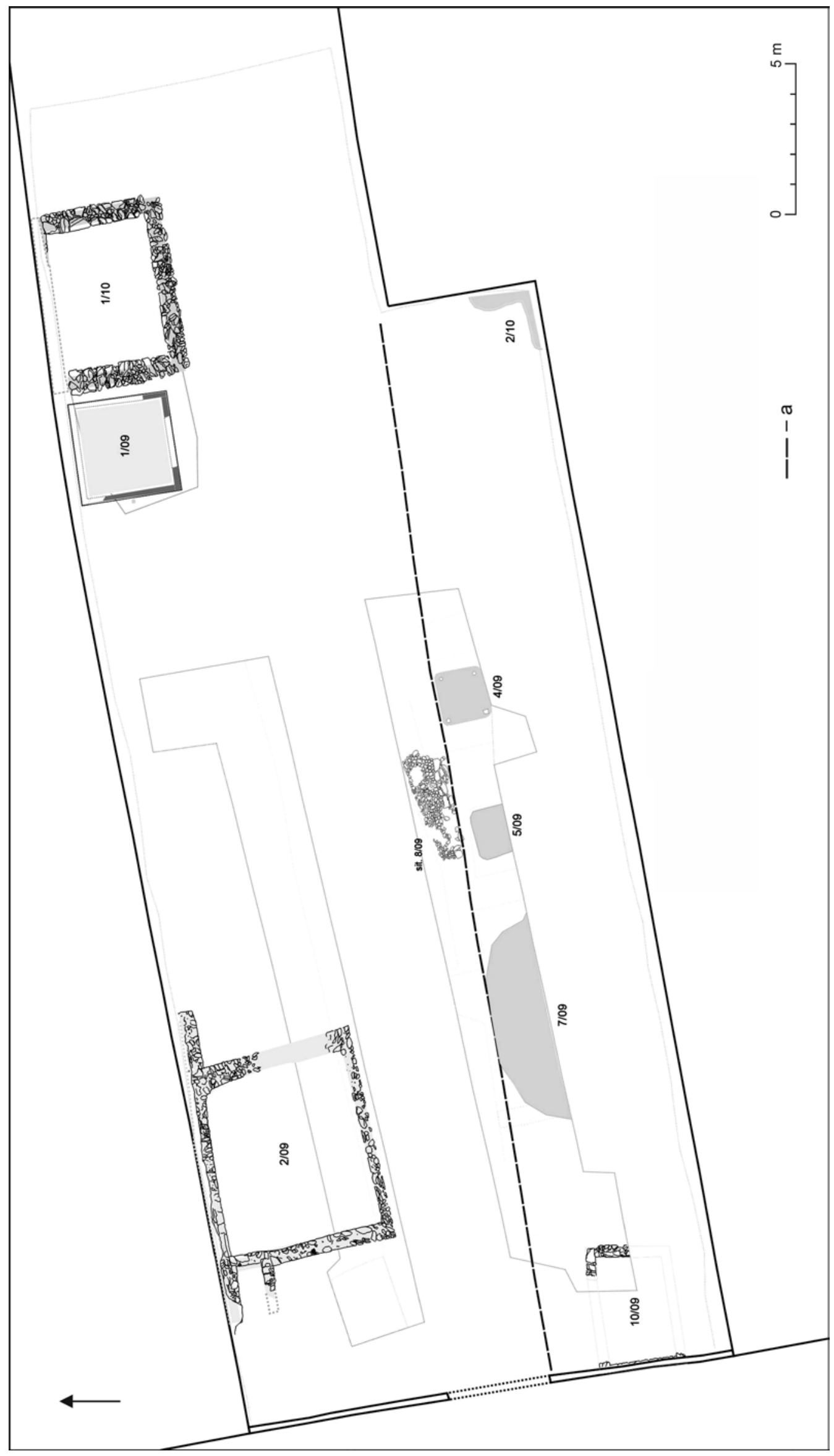


At the time of writing, several medieval and early modern structures in Košice have been recorded and interpreted as cold stores or ice houses. The find which matches most closely to the description of a cold store was a quadrilateral structure with dry-laid stone walls discovered at Hlavná 58 which had been partially destroyed during construction work. The walls of the structure inclined slightly inwards and at its widest point had interior dimensions of $230 \times 150 \mathrm{~cm}$. Most significantly, several levels were identified in the structure which were formed of beams with boards (Čaplovič 1990, 94). Within the cold store at Hlavná 58 a representative collection of medieval kitchenware and tableware was found in addition to an iron key, a complete wooden measuring bowl, carved wooden handles, leather boots and fragments of glass vessels. Thanks to paleo-botanical and archaeozoological analysis, we know that the cold store contained supplies of cherries, apples, plums and grapes but also pork, beef, mutton, venison and goat meat. Pork was found to predominate, especially higher value cuts of meat. According to the author of the study, the cold store was in use from the $14^{\text {th }}$ to $15^{\text {th }}$ centuries, suggesting that the structure had fallen out of use before the end of the $15^{\text {th }}$ century (Čaplovič 1990, 96). On the basis of the overall character of the ceramic finds, it would, however, be possible to revise the period of the abandonment of the structure to the early $15^{\text {th }}$ century, or the first half of the century respectively (Rusnák 2009, 59). Four late medieval to early modern structures found in the courtyard of the house at Kováčska 24 have also been interpreted as cold stores. The structures are known to have had dry-laid stone masonry, although the results of the survey have not been published in detail (Gašaj 2015). This is also the case for two similar structures found during a survey of the courtyard at Hlavná 27 (Haruštiak/Roth/Vereščáková 2012). A further possible fragment of this type of structure was uncovered in the courtyard of the Bishop's Palace at Hlavná 28. Building excavations revealed fragmented masonry of dry-laid quarried stones and a related occupational layer rich in late medieval ceramic material (ĎurišoválUličný 1999). A partially revealed structure with an almost identical floor plan to that of feature 4/09 at Mäsiarska 57/A was found in the courtyard of the house at Kováčska 37 (Šimčík 2013). The structure was dated to the $16^{\text {th }}$ and $17^{\text {th }}$ centuries and was interpreted as an icehouse although no traces of its building construction were discovered during the survey. One other similar structure was found at Mäsiarska 57/A in the close vicinity of feature 4/09 (feature 5/09; Rusnák 2014, 325), but, again, no traces of its construction could be determined during the survey.

Although the investigation results of several of these structures have not been published, from the information which we have at our disposal it is clear that, with the possible exception of the structure at Hlavná 58, the identification of these structures as cold stores on the basis of the situation of their finds is by no means certain and it must be assumed that they were uncovered in a state in which they had already fulfilled their later roles as waste pits. The ambiguities in interpreting these structures only highlights the low level of attention which has been focussed on this topic in Slovakia.

\section{COLLECTION OF FINDS}

The collection of finds excavated from the infill of feature 4/09 is extraordinarily abundant. The assemblage is formed of ceramic vessels ( 74 accession numbers) and tiles ( 7 accession numbers), glass vessels and other objects (22 accession numbers), fragments of ceramic building materials, bricks and tiles (6 accession numbers), small objects from iron, bronze, glass and stone (16 accession numbers), as-yet-unanalysed plant seeds ( 3 accession items), charcoal (1 accession number) and animal bones (13 accession numbers).

\section{Clay objects}

The clay objects were ceramic vessels, tiles and ceramic building materials. No clay pipes were found. The extremely sizable collection of potsherds from ceramic vessels indicates the existence of almost 650 individual ceramic objects, $14 \%$ of which could be physically reassembled either almost completely or in their greater part. Even in cases of objects which could not be reconstructed but which still possessed significant shard material it was still possible to pick out individual ceramic objects and determine their shape and function. Among the ceramic vessels are clay pots, mugs, jugs, juglets, beakers, money boxes, cups, lids, dishes and several types of bowls (including tripods, mortars and colanders). General information about the ceramic assemblage is given in Table 1. 
Table 1. Košice-Mäsiarska 57/A. Table of ceramic finds. Legend: A - Type of vessel; B - number of identified ceramic objects; C - number of ceramic fragments; D - potter's clay (D1 - white clay, D2 - pink-red, pink-brown fine clay, D3 - pink-white fine clay, D4 - yellow-white fine clay, D5 - yellow, pink, red sintered clay, D6 - ferrous clay, brown, red, orange, D7 - undetermined due to damage - burning); E - glaze (E1 - transparent green glaze, E2 - transparent yellow glaze, E3 - transparent brown glaze, E4 - combination of transparent green and yellow glazes, E5 - transparent green-yellow glaze, E6 - transparent yellow-brown glaze, E7 - undetermined due to damage - burning); F - slip (engobe).

\begin{tabular}{|c|c|c|c|c|c|c|c|c|c|c|c|c|c|c|c|c|c|c|}
\hline \multirow{2}{*}{ A } & \multirow{2}{*}{ B } & \multirow{2}{*}{$\%$} & \multirow{2}{*}{ C } & \multicolumn{7}{|c|}{ D } & \multicolumn{7}{|c|}{ E } & \multirow{2}{*}{$\mathrm{F}$} \\
\hline & & & & D1 & $\mathrm{D} 2$ & D3 & D4 & D5 & $\mathrm{D} 6$ & D7 & E1 & E2 & E3 & E4 & E5 & E6 & E7 & \\
\hline 1. Colander & 1 & 0,2 & 1 & - & - & - & - & - & 1 & - & - & - & - & - & - & - & - & - \\
\hline 2. Jug & 20 & 3,1 & 41 & 13 & 1 & - & 1 & 2 & 3 & - & 3 & - & - & 8 & 1 & - & - & 5 \\
\hline 3. Juglet & 34 & 5,3 & 93 & 11 & 6 & 3 & 2 & 3 & 9 & - & 7 & 5 & - & 9 & - & - & - & 3 \\
\hline 4. Jug/beaker & 69 & 10,8 & 212 & 9 & - & - & - & 60 & - & - & 2 & 1 & - & 9 & - & - & - & - \\
\hline 5. Bottle & 2 & 0,3 & 2 & 1 & - & - & - & - & 1 & - & - & - & - & - & - & - & - & - \\
\hline 6. Clay pot & 251 & 39 & 1061 & 28 & 31 & 8 & 9 & - & 175 & - & 34 & 39 & 6 & 18 & 10 & 3 & - & $?$ \\
\hline 7. Clay pot/jug & 68 & 10,6 & 308 & - & 10 & 28 & 8 & - & 22 & - & 34 & 10 & - & 11 & 8 & - & - & - \\
\hline 8. Mug & 32 & 5,0 & 163 & 7 & 1 & 8 & - & - & 16 & - & 6 & 6 & - & 5 & 2 & - & 1 & - \\
\hline 9. Miniature vessel & 2 & 0,3 & 4 & 2 & - & - & - & - & - & - & 1 & - & - & - & - & - & - & - \\
\hline 10. Bowl & 54 & 8,4 & 92 & 15 & - & - & - & - & 5 & 34 & 15 & - & - & - & - & - & 34 & - \\
\hline 11. Mortar bowl & 6 & 0,9 & 19 & - & 2 & - & - & - & 4 & - & - & - & - & - & - & - & & - \\
\hline 12. Tall-form vessel & 34 & 5,3 & 56 & 5 & - & - & 9 & 3 & 17 & - & 11 & 3 & 3 & 2 & - & - & 1 & 3 \\
\hline 13. Tripod & 22 & 3,4 & 31 & - & - & - & - & - & 22 & - & - & 21 & - & - & 1 & - & - & - \\
\hline 14. Beaker & 4 & 0,6 & 4 & 1 & - & 1 & 2 & - & - & - & 4 & - & - & - & - & - & - & - \\
\hline 15. Money box & 5 & 0,8 & 5 & - & 3 & - & - & - & 2 & - & - & - & - & - & - & - & - & - \\
\hline 16. Lid & 14 & 2,2 & 14 & - & - & - & - & - & 14 & - & - & - & - & - & - & - & - & - \\
\hline 17. Cup & 13 & 2,0 & 31 & - & - & - & - & - & 13 & - & - & 4 & 1 & 1 & 2 & - & - & - \\
\hline 18. Dish & 8 & 1,3 & 8 & - & - & - & 3 & - & 5 & - & 2 & 2 & - & - & 3 & - & 1 & 2 \\
\hline 19. Dish/bowl & 3 & 0,5 & 3 & - & - & - & - & - & 3 & - & - & - & - & - & - & - & 3 & - \\
\hline Together & 642 & 100 & 2148 & & & & & & & & & & & & & & & \\
\hline
\end{tabular}

\section{Clay pots}

Clay pots are the most numerous form within the ceramic category of the assemblage from feature $4 / 09$, representing $39 \%$ of all items. We expect to identify even more clay pots among the group of ambiguously classified types of vessel (clay pots/jugs, tall-form shaped vessels) so it is likely that the number of clay pots in the collection could be higher still. Thirty one individual items have been reconstructed. The majority of these $(70 \%)$ were made from untreated clay with either higher or lower levels of ferrous particles with a noticeable share of likely naturally occurring sand (Table 1: D6) which is evidently a distinctive feature of the site from which each production material was obtained. Clay pots produced from a less ferrous fine clay of pinkish-brown and pinkish-red colours (Table 1: D2; $12 \%$ ) and of white clay (Table 1: D1; $11 \%$ ) appear at a roughly similar proportion, and a strong component of the collection is also comprised of pots made from pinkish-white (Table 1: D3; $3 \%$ ) and yellowish-white fine clay (Table 1: D4; $3.6 \%$ ). The clay pots obtained from Mäsiarska Ulica in Košice are S-shaped with concave contouring in the upper third of the vessels (Pl. I: 1-3, 5-8, 10-15; XVIII: $3-8$; XIX: 1, 2, 5-8). While the majority of the vessels have an ovoid shape, barrel-shaped profiles with a tendency toward rounding are not unknown (Pl. I: 4; XVIII: 2), in some isolated cases with a levelled, 
almost cylindrical appearance (Pl. I: 9; XVIII: 9). In half of the reconstructed objects marks of trimming can be observed in the lower part of the vessels. In many cases these $0.5 \mathrm{~cm}$ deep traces appear on the inner surface and gradually disappear in the region of the concave and upper parts of the vessel. The material used in producing the clay pots can be characterized as ferrous clay which takes on a light brown colour after oxidative firing, although there are examples produced from clay with a far higher ferrous content which acquire a red or reddish-brown colour. The surface of the pots is rough which is the result of the pottery clay itself which was in many cases supplemented with raw materials obtained from pulverized stone. The bases of the vessels show signs of handling after throwing indicating that they were often only lifted from the wheel although a significant portion of the pots were cut off with a string. The bases are predominantly flat, occasionally appearing gently concave, an effect which is a later result of drying and firing. The outer surface is untreated while the inner surface is treated with a transparent glaze. Examples of glazing on outer surfaces are rare and unintentional, apparently accidental residues from the application of the glaze. Coloured glazes are common, yellow (Table 1: E2; $36 \%$ ), green (Table 1: E1; $31 \%$ ) and brown (Table 1: E3; $5.5 \%$ ), while specific colour transitions also appear between yellow and green glazes in the form of a mottled greenish-yellow (olive) glaze (Table 1: E5; $9 \%$ ). In all cases, the glaze had been applied directly onto the surface of the vessels. As a rule when applying glaze to tall-form vessels, the coating of the inner surfaces is less rich and is coloured less intensely, while the inside of the spout and mouth are treated with a more strongly coloured glaze of the same shade as the inner surfaces, although often the choice of colour alternates between green with yellow and brown with yellow (Table 1: E4; $16 \%$ ). Yellow glaze appears most often on the inner surface of the vessels, followed by less pronounced shades of green. The manufacturers of the pots fired the glazed vessels in a kiln with an oxidizing atmosphere, but it was not unknown for the firing process to take a different course as is indicated by the isolated cases of fractures observed in several of the pots. Reddish-brown colouring in the core and dark greyish-black on the surface suggests that a reducing atmosphere may have occurred at specific points in the firing process. Occasional examples of smoke damaged ceramics also occur in the collection; fifteen potsherds from four ceramic objects showed such signs, representing only $1.6 \%$ of the complete assemblage. All of the clay pots in the collection have a single strap handle. Indentations, often markedly so, are characteristic of these handles which is indicative of modelling by hand. Handles are typically attached directly on the mouth of the vessel and connected at the highest point of the concave, typically at the lower part of the shoulder. They are most commonly level with the rim but in a number of examples the handles project $1-2 \mathrm{~cm}$ above (Pl. I: 2, 6, 14; II: 7; XIX: 3, 5). In the majority of the clay pots, the positioning of the handles is noteworthy when we observe how they are offset on the vertical plane. From the perspective of a user who is holding of the vessel in their hand, the line of the handle curves to the right as it runs from bottom to top. While this may be the result of negligence in the manufacturing process, the abundance of examples of this feature means that we cannot exclude the possibility that it may be an attempt to simplify the practical use of the product for the user. The decoration of clay pots was not a priority. The only type of decoration found on the objects from the Košice collection is shallow incising around the neck and, most commonly, only on the shoulder of the vessel which are bordered from below by grooves of varying widths (Pl. I: 1, 3, 7, 12, 14; II: 4, 10, 13; XIX: 2, 9) or by lines painted with ochre-red clay (Pl. I: 6; XVIII: 6). A deep groove frequently appears just below the rim of the vessel (Pl. II: 6; XIX: 4) and also, less commonly, two such deep grooves (Pl. I: 2). The spouts of the pots are bent, often below the angle formed from the outer rim in order to allow the vessel to be sealed with a lid (Španihel 2016, fig. 2: $4 a, 4 b, 5 a, 5 c)$. The predominant form on the rim is a simple rounding (Pl. II: 1$)$ with occasional variations with bevelling or chamfering (Pl. I: 14). In terms of dimensions, clay pots are the most diverse group among the tall-form vessels in the assemblage, with heights ranging from $17-23 \mathrm{~cm}$, diameters at the mouth from $13-18 \mathrm{~cm}$ and at the base from $8.5-12.5 \mathrm{~cm}$. In almost all cases, the clay pots in the assemblage are pots intended for so-called 'lateral heating' (Štajnochr 2004), vessels which are characterized by the base of the pot being approximately half the diameter of the rim, untreated outer surfaces, a single substantial handle and heavy wear on the side opposite the handle (Pl. XVIII: 2; XIX: 4-6, 9), where in addition to blackening and secondary burning, surfaces may also show traces of grease and organic residues which may have arisen during use. 


\section{Mugs}

Mugs are a variant of clay pots which differ from the latter in their substantially smaller dimensions and, in several cases, in the material used in their production. Mugs share the S-shaped body of the clay pots with a maximal concave in the upper third of the vessel (Pl. II: 1-4; III: 3, 4, 6, 8, 9; VIII: 6; XVII: 1, 4). They are most commonly produced from clay which does not differ from that used in the clay pots (Table 1: D6; $50 \%$ ). The clay is less ferrous with a natural sand content which gains a light brown colour after firing. Examples are found which are made from a strongly ferrous clay which acquires a reddish-orange colour upon firing. At the same time, however, we can also come across items made from pinkish-white (Table 1: D3; $25 \%$ ) and white kaolinite clays (Table 1: D1; $22 \%$ ) which are most typically used in the production of tableware. The mugs were routinely thrown on a wheel but in two cases, however, marks of trimming can be detected on the inner surface of the vessels. As with the clay pots, the outer surface of the mugs is generally unworked with the difference that we can observe a greater precision in the final overall appearance of the vessel. This is most evident in the reduction of surface marks after modelling, especially in the smoothing of the base after removing the object from the wheel. Due to their smaller size, the handles of the mugs are predominantly rod handles with isolated examples of strap handles although there are many examples of handles which are transitions between these two categories. The offset to the right on the vertical plane seen in the clay pots is still recorded. The formation of the spout and rim copies that of the clay pots and this also applies for the thick incising around the neck and shoulder of the vessel respectively extending to the start of the maximum concave (Pl. III: 4, 6, 8, 9). In some cases, the area of this incised decoration is bordered with a deep groove. The method of glazing is identical to that of the clay pots, where the interior is coated with a less intensely coloured glaze, typically of yellow colour, and the inner side of the spout coated with a thicker and conspicuously more coloured (green) glaze (Table 1: E4; $25 \%$ ). Given the small size of the vessel, it is common to find that the inner surfaces of the mugs have been coated with a single type of glaze, and the occurrence of green and yellow transparent glazes are equal (Table 1: E1, E2; $30 \%$ ). None of the objects were recorded with transparent brown glazes, but more notable are the number of completely untreated items $(38 \%)$. The dimensions relate directly to those of the smallest clay pots, with heights ranging from $11-17.5 \mathrm{~cm}$, the diameters at the mouth from $7.5-12 \mathrm{~cm}$ and at the base from $5-9 \mathrm{~cm}$. The small vessels were also used in the preparation of cooked food using laterally heating in the same manner as the clay pots, with many of these single handled objects displaying strong traces of blackening and contact with fire on the outer surface of the side opposite the handle (Pl. I: 1, 4).

\section{Jugs and juglets}

Jugs and juglets are a distinctive category of ceramic tableware which are distinguished by the material of their manufacture and the high incidence of decoration. They are most typically made from fine white (Table 1: D1; $65 \%$ for jugs and $32 \%$ for juglets), yellowish or pinkish kaolinite clay, occasionally from more common potter's clay which contains no sand but is also less ferrous and acquires a lighter brown, red and orange colour after firing (Table 1: D6; $26.5 \%$ for juglets). Products made from less ferrous clays were, as a rule, applied with a white or cream slip (Table 1: F; $15 \%$ for both jugs and juglets). Emphasis in the production of this type of tableware was placed on the choice of more refined clays whose positive qualities lay in their aesthetic appearance rather than the practical functionality typically expected from kitchenware such as resistance to contact with fire. The proportion of kaolinite clays of white or other colours in the collection is very high (up to $78 \%$ of all jugs and juglets). It is questionable whether the Košice region would have been able to supply potters with sufficient quantities of such clay in this period. There is no detailed topography available of these types of small scale deposits in east Slovakia nor apparently of now exhausted sites which had been worked for long periods in the past. Nonetheless, the possible existence of these sites is indicated by now unused and almost forgotten local place names, for example, "Biela Hlina" (White Clay) in Župčany, "Biele Hliny" (White Clays) in Kechnec and "Biela Hora" (White Hill) in Pozdišovce and Michalovce, or by accidental finds of white clay deposits revealed during excavation work in the Prešov region.

In the category of jugs, we include globular vessels with a tall cylindrical neck which can be either simply inclined (Pl. VIII: 5, 8; IX: 9; X: 9; XI: 6, 8) or slightly profiled and drawn out (Pl. VIII: 4, 9; XI: 5, 
7). Both variants have miniature versions of identical form. These juglets are certainly derived from the jugs mentioned above with cylindrical necks (Pl. IX: 4, 5; X: 5, 7) or variants of jugs with wide tapered cylindrical necks on a globular body with an offset base which bear some resemblance to several small clay pots in the assemblage (Pl. IX: 6, 7, 10, 11; X: 6, 8, 11). Other jugs have a markedly narrow neck and pear-shaped body with a lip-like shape to the spout and a hollow handle with a vented opening which is sealed with a button, indicating that these vessels are a form of cooler jug. Jugs of this type were intended to store liquids at cool temperatures and are known by several regional names such as "hrkáč" in Pukanec (Polonec/Turzová 1962, 27), "koršov" in Pozdišovce (Plicková 1959, 70, fig. 48) or "zbanka" in Trstená (Kulášová/Ďurčo 2019, 63). The intended function of the larger jugs - the storage of water or other liquids - is clear from the glazing on the outer surface extending down to the bottom third of the vessels and, in the case of the narrow-necked jugs which are closed with a sieve-like screen at the spout, by the unglazed porous shard kept within the interior of the vessel. In contrast, the miniature jugs are instead completely glazed, suggesting that they were used as cups or mugs or even as toys, although an ornamental use cannot be ruled out either. All of the jugs feature a characteristic offset base or in some cases a more distinctive moulded foot. The jugs with wide mouths have a substantial, slightly bent strap handle connected at a level halfway between the mouth and the edge of the shoulder and at the maximum concave. The rims are rounded simply and between one and three shallow grooves are incised around the upper part of the mouth. The border between the shoulder and neck is marked with a moulded band. The jugs in the assemblage with tapered, conical mouths appear in two size categories: a larger group with a height of between $26-27 \mathrm{~cm}$, a diameter at the mouth of $8-9 \mathrm{~cm}$ at the base of $9 \mathrm{~cm}$, and a smaller group with a height of between 21-22 cm, a diameter at the mouth of $7-8 \mathrm{~cm}$ at the base of $7 \mathrm{~cm}$. In comparison with these vessels, the concave of the cooler jugs is positioned markedly towards the lower third of the vessel. The mouths terminate with a thickly perforated sieve-like screen below which leads a hollow handle with a vented opening behind which follows a seal button. The dimensions of the cooler jugs are only partly known: the height is $26 \mathrm{~cm}$, the diameter at the mouth $6-6.8 \mathrm{~cm}$ and at the base $9 \mathrm{~cm}$. The decoration of the cooling jugs shares the shallow incised grooves around the mouth, narrow neck and shoulder seen on other vessels, however glazing is the predominant form of decoration. This is typically in the form of a monochromatic layer of transparent glaze or polychromatic glazes of two sharply delineated colours one on the outer surface and the other in the mouth of the vessel (Pl. VIII: 2, 5; XI: 6) or in defined parts of the vessel (Pl. VIII: 3; XI: 4). Other examples of this are the trailing of lines of green and brown glazes over a base slip beneath a transparent yellow surface glaze (Pl. VIII: $8 ;$ XI: 8) and the trailing, spraying and splashing of brown and ochre-red clays and green glazes over a base slip to create a tracing and marbling effect beneath a transparent yellow glaze (Pl. VIII: 1 , 9; IX: 7; X: 8; XI: 3, 7). Small areas on jugs with wide mouth and juglets offered space for stylized decoration in the form of S-shaped scrolls or deep ripples traced through the clay in earthy colours with the aid of a stalk or horn, with the peaks filled alternately with clay and green glaze (PI. VIII: 4; IX: 6; X: 11; XI: 5). Another form of stylized decoration is the rings of leaf motifs painted around the shoulders and concave (Pl. VIII: 4; XI: 5). A similar approach is the application with stalks or horns of stylized geometric motifs (for example spirals and half-moons) in earthy clay coloured with blue dye on a white slip beneath a transparent yellow glaze (Pl. IX: 10, 11; X: 6). In addition to the types of jug discussed above, one other example belongs with in this category, a pear-shaped vessel a low concave and a long narrow neck (PI. III: 7; XVI: 5). This untreated object with a height of $18 \mathrm{~cm}$ and a diameter at the base of $6.5 \mathrm{~cm}$ present itself as belonging to the category of bottles, but the fact that it was originally provided with an arched rod handle signifies that it is in fact another variant of jug (Scheufler 1972, 31, tab. VI: 134).

\section{Beakers}

This type of ceramic tableware, represented by many examples including some which have been almost completely reconstructed, were also made on the whole from fine white or yellow kaolinite clays. (Table 1: D1, D3, D4). All of the objects in this category share a characteristic conical-shaped body, but they can be divided into three categories on the basis of other modifications in form. The first of these modifications takes the form of a cylinder with an offset base which disrupts the overall coni- 
cal appearance of the vessel. It has a roof-like bevel on the rim which is reminiscent of a broad collar (Pl. IX: $3 ; \mathrm{X}: 1$ ) and the interior is coated with a transparent green glaze. Given the small dimensions of the vessel (height 7.6-7.8 cm, diameter at the mouth $5 \mathrm{~cm}$ and at the base $5.3 \mathrm{~cm}$ ) and its resemblance to finds from Strachotín in Moravia (Pajer 2001, fig. 47: 1), we cannot exclude the possibility that the objects may have been used as children's toys. A further three examples have either a chalice-like appearance (Pl. IX: 8; X: 4) or resemble goblets (Pl. IX: 1, 2; X: 2, 3). In the latter case, the vessels may have been inspired by glassware equivalents. The chalice-like vessels either set on a base or with base-like markings and a third example with a maximum preserved height of $10.4 \mathrm{~cm}$ and a base diameter of $6.5 \mathrm{~cm}$ were originally fitted with rod loop handles. One preserved handle and a single fragment indicate that the beakers also had handles which were offset to the right on the vertical plane. Almost the entire surface of these beakers was coated with a transparent green glaze. They are unadorned, although they are decorated in the form of shallow grooves incised around the mouth, shoulder and base. The two chalice-like vessels had a height of $8 \mathrm{~cm}$ and a diameter at the mouth of $6-7 \mathrm{~cm}$ and at the base of $4.6-5.2 \mathrm{~cm}$.

\section{Money boxes}

A particularly interesting form in the collection are the four (potentially five) identified money boxes, two of which have been reconstructed. These are easily identifiable objects with an unmistakeable function. The small, untreated objects were made on the wheel with ordinary, less ferrous clay without coarse particles, so the surface takes a light brown colour after firing. Two variations are found. The first form is a small, slightly oblate, spherical object with an offset base. A horizontal slot for inserting coins is positioned on the shoulder of the object. The object is decorated with a deep groove around the body at the level of maximum concave (Pl. III: $1 ; \mathrm{X}: 13$ ). The height of the object is $4.1 \mathrm{~cm}$ and a maximum diameter of $5.7 \mathrm{~cm}$. The form of the object is almost identical to that of an object found with the large trove of $15^{\text {th }}$ century coins in Šahy (Kraskovská 1980, 91, 92, fig. 1: 4). The second almost complete money box resembles the first in shape, but the upper part lacks the oblate shape and has instead been shaped upwards by the potter to a blunt inclined tip (Pl. III: 2; $X: 12)$. The coin slot has a width of $3.7 \mathrm{~cm}$ and is positioned vertically on the shoulder of the object. The money box has a height of $12.8 \mathrm{~cm}$ and a diameter at the base of $5.5 \mathrm{~cm}$. An analogous container with a domed shape topped with a knob was submitted to the Institute of Archaeology of the Slovak Academy of Sciences after being uncovered during reconstruction work on Hlavná in Košice in the mid 1990's, and L. Kraskovská has described another similar money box dating to the $16^{\text {th }}$ century which was found in Ménfőczanak in Hungary (Kraskovská 1980, 87, note 21). Feature 4/09 at Mäsiarska 57/A in Košice has furnished smaller sherds from another spherical money box and also a fragment from an analogous container. While similar in terms of form, material and manufacture, this fragment differs through the presence of fragmentary descending curved openings, on the basis of which we now consider the fragment to lie outwith the category of early modern pottery (Pl. X: 14). The production of ceramic money boxes was already common by the period of the High Middle Ages in the Czech lands, Slovakia, Hungary and Poland (Kraskovská 1980, 87, 88; Scheufler 1972, 47, note 59, tab. VI: 146).

\section{Miniature vessel}

A unique miniature vessel also appears in the ceramic collection, a thick-sided object which was moulded by hand from white clay (Pl. X: 10). The flattened, roughly spherical body of the vessel terminates in two opposing vertical handles similar to those seen on platter dishes, while neither the mouth nor the base survives. The handles were probably used to hang the vessel. The outer surface is coated with a transparent yellow glaze. The lower section does not terminate in a base but is instead simply rounded. The body of the vessel has a height of $6.5 \mathrm{~cm}$, a width of $5 \mathrm{~cm}(6 \mathrm{~cm}$ when the handles are included), while the fragments are $0.4 \mathrm{~mm}$ thick. While the miniature vessel could conceivably have served to store valuable liquids, it is more likely to have been used as a children's toy. 


\section{Cups}

Thirteen cups appear in the collection of finds, smaller vessels of a flattened S-shape (Pl. IV: 1-6; XVI: 1-3, 6) made from the same unworked ferrous clay as was used in the production of the clay pots (Table 1: D6). In several cases a less ferrous clay was used, indicated by the lighter brown colour of the surface. From the seven objects which could be reconstructed, four cups were untreated while the others had a coating of transparent glaze on their inner surfaces, with colouring, most commonly yellow (Table 1: E2; $50 \%$ ) but also brown or yellow-green, extending only to the outer side of the mouth. This short form of vessel has a height ranging from $6.5-9.5 \mathrm{~cm}$, a diameter at the mouth of between $8-14.5 \mathrm{~cm}$ and at the base of 7-9 cm. A single rod handle is typically attached to the rim and lower part of the concave and is usually level with the rim, only in one example displaying a projection above of $1 \mathrm{~cm}$ (Pl. IV: 5). The handles of the cups also show a noticeable offset to the right on the vertical plane. The outer surfaces do not bear any traces of detailed working or smoothing and the base shows signs of removal from the potter's wheel. In one example, there are deep marks of trimming on the inner surface of the cup. The bases of all of the reconstructed cups are slightly concave. The decoration is identical to that of the clay pots, shallow grooves running around the neck and extending down to the lower part of the shoulder (Pl. IV: 2-4). On several of the cups there are noticeable traces of fire and heavy blackening on the side opposite the handle similar to those caused by lateral heating on the clay pots (Pl. XVI: 1).

\section{Bowls and dishes}

Of the sixty five identified bowls and platter dishes in the assemblage (Table 1: 10, 18, 19), five items have been reconstructed. This tableware is predominantly made from white clay $(23 \%)$, however, one remarkable feature which is not recorded to such an extent for other types of ceramics is the high proportion of wide-form vessels which are heavy damaged by smoke. The damage is often to such a degree that it is even impossible to determine the type of clay used in their production (52\%) or to detect the presence of glazing or underglaze decoration which is particularly characteristic for this type of object (Table 1: D7, E7). The extensive fire damage on such a large number of dishes is likely connected to their use in the kitchen for the preparation of food, cooking and baking and their use as replacement lids, an object which is only rarely recorded in the assemblage. Three of the reconstructed examples were made from yellowish-white kaolinite clay and were coated over the entirety of their inner surface with a transparent green glaze (PI. VII: 1, 3, 4; XI: 1; XVI: 9, 10). Common ferrous or less ferrous clays were used in the production of the other objects which gives the surface colours ranging from brick red to light brown to orange (Table 1: D6; $20 \%$ ). The shallow wide-edged variants of the bowls have a diameter at the mouth which ranges from $20-36 \mathrm{~cm}$ and at the base from $9.5-12.5 \mathrm{~cm}$ with a height from $4.5-8.5 \mathrm{~cm}$. The objects were thrown skilfully on the potter's wheel but in the case of the items made from white clay there is a surprising lack of additional working or smoothing; on the contrary, we can see several irregularities, marks of manipulation made when the bowl was still wet and fingerprints. This also corresponds to the method of forming handles on these shallow white clay bowls. The small horizontal tunnel handles are clumsily modelled, with an unworked appearance which contrasts markedly with the similar handled platter dishes made from ferrous clay. One exception to this are the small horizontal strap handles found on the painted platter dish (PI. VII: 2; XI: 2). The offset base is level or slightly concave, with traces of removal from the wheel, and several examples have been worked further. The stepped double incline form typically opens out to a level mouth with a simply rounded rim, although a flat collar also occurs (Pl. VII: 1, 4). A flat shallow bowl or platter was also found with a very slight double incline profile to the sides and a similarly worked rim (Pl. IV: 9). A cream white slip was applied to the surface, while decorative motifs were applied in coloured clay with a stalk or horn, but the colour of the top glaze cannot be determined due the negative effect of the environment of the infill of the find site. The majority of platter dishes made from ferrous clay were decorated with painting which was typically applied directly onto the surface of the dish without the use of a base slip. Decorations were typically divided into two sections: the lip and the well of the dish. The most common arrangement is white, brown or ochre clays applied with the aid of a horn (or stalk) with each of the alternate sections being filled either with the same colour, a different colour or a glaze (or some combination thereof), and the entire surface treated with a transparent glaze coat. The decoration on the lip 
of the dishes is highly stylized, with floral and geometrical motifs or a combination of the two, often representing an abstract conceptual ornamentation, perhaps inspired by other fields such as dressmaking, architecture etc. The well of the dish offers the most suitable space for the execution of a central decoration; however, the craftsman often fails to take full advantage of this opportunity, placing instead stylized decorations in the form of a spiral, undulating lines or rings of concentric circles (Pl. XVI: 4). In one case it was possible to reconstruct the central decorative motif which consisted of a stylized floral theme: a central multiple stalk with three pairs of leaves or tendrils in the form of left-leaning spirals (Pl. VII: 2; XI: 2). Decoration displaying various regional features, simplifications or stylizations may become a major incentive for identifying local workshops. At the time of writing, however, there is a distinct lack of published work on products from the Košice region. Up to $92 \%$ of the wide-form objects were glazed with an apparent preference for green glaze $(28 \%)$ although the actual situation may be different given the high proportion of damaged items (Table 1: E7; $58.5 \%$ ).

Within the category of wide-form dishes from the assemblage found at Mäsiarska 57/A we can include a further variety of bowl: mortars (or grinding bowls) and colanders.

The presence of six mortars in the collection is indicated by several fragments from which it was possible to reconstruct a bowl-shaped vessel with conical sides sloping down to the original flat well (Pl. IV: 7). The vessel was thrown from ferrous sandy clay of thicker structure which acquired a brick red colour after firing. The diameter at the mouth is $24 \mathrm{~cm}$ and the preserved height is $12 \mathrm{~cm}$. The vessel was untreated with a rough surface and may have originally been fitted with either one or two handles. Around the outer surface of the mouth and extending down to the shoulder, the bowl is decorated with sections of wide straight grooves and undulating lines. Mortars are a type of kitchenware which was used to grind poppy seeds. The fragments of mortars found in feature 4/09 are not necessarily contemporary with the collection of ceramic finds and the possibility that they may be an intrusion into the collection cannot be excluded.

The colander bowl is a shallow untreated vessel with a conical or hemispherical body, a thick level base and is irregularly perforated with a large number of small openings with a diameter of between 1 and $3 \mathrm{~mm}$ (Pl. IV: 8; XVI: 8). The vessel was made from less ferrous clay with a light brown colour. No handle has been preserved, but the vessel may have been provided with a slender rod handle. The mouth is inclined, the rim is level and slightly tilted to the outside. The deep grooves around the outer surface of the lip may be considered as a form of decoration. The colander was a type of kitchenware used for separating liquids (Horvat 1999, 173).

\section{Lids}

Within the group of flat dishes, we can also find a small number of lids ( $2.2 \%$ of the collection of finds), of which one item has been reconstructed. The conical, plate-like body was thrown on the wheel together with the double-cone knob handle (diameter $3.7 \mathrm{~cm}$; Pl. I: 11; XVI: 7). The lid is made from a particularly unimproved ferrous clay which acquired an orange-brown colour after firing (Table 1: D6). The mouth is slightly inclined, and the rim is simply rounded and partially angled outwards in order to keep the object more secure in its function of covering the vessel. The shallow grooving around the entire lid may be a form of unintentional decoration. The diameter at the mouth is $19 \mathrm{~cm}$ and the height is $5 \mathrm{~cm}$. Smaller fragments of a further thirteen examples are indicative of a similar type of lid, but they are thicker with a more substantial inward angle below the lip and trimmed from a visibly coarser clay which is more suggestive of their being an intrusion from the late medieval period.

\section{Tripods}

Tripods are shallow items of kitchenware intended for direct contact with fire during frying. They are bowls with rounded sides extending down to an approximately level base with a depth of $9.5-15 \mathrm{~cm}$. They have a regular round shape with a diameter at the mouth of $17-19.5 \mathrm{~cm}$ although examples also occur with a slightly modified mouth with the dimensions of $19 \times 17 \mathrm{~cm}$. The diameters of the bases range from 7.5 to $14 \mathrm{~cm}$. From the twenty two identified examples ( $3.4 \%$ of the collection of finds) found at Mäsiarska 57/A in Košice, three objects have been reconstructed. All three were made from a coarse ferrous clay with sand which acquired a brown or maroon colour after firing (Table 1: D6). The rounded 
sides of the bowl and legs incline in one case to a curved mouth with a simply rounded rim and in two cases the mouth is inclined straight upwards to a thickened collar with the rim drawn inwards. The tripods consist of approximately hemispherical bowls with a grip in the form of a hollow shaft. Three legs, one beneath the shaft and two on the opposite side, are used to place the vessel over the fire in an open fireplace (Mešša 2013, 16-18). In three cases, the grip is an open socket-like structure into which a wooden handle could be inserted to allow simpler handling over an open fire during the cooking process (Pl. III: 5, 11; XVII: 2, 3). These shafts have a diameter of $1.4 \mathrm{~cm}, 2.7 \mathrm{~cm}$ and $5.3 \mathrm{~cm}$ and are between 8 and $9 \mathrm{~cm}$ long. The opening of the shaft has been strengthen by fingered moulding. Also recorded, however, are examples with shafts which are sealed with a "nipple"-like end (Pl. III: 10; XVII: 5). The design of handles over the course of the early modern period was related to the requirements of the kitchen and its specific features such as the open fire and the methods and capacities of food preparation. The tripods had to withstand the stress of high temperatures and could become compromised even when being maintained and cleaned of grease which accumulated on the vessel during frying, the predominant use for this type of vessel. There were considerable differences between the lifespan of tripods and other cooking vessels (Oniszczuk 2016, 92, 94). Ordinary pots were simple and replaced cheaply, while tripods would be made on the basis of a specific demand. This made to order approach clearly had an impact on requests for different forms of handles which may explain the simultaneous occurrence of both types of handle throughout the early modern period. The height of the bent legs is measurable for two of the vessels and was between 5-10 $\mathrm{cm}$. A transparent yellow glaze was applied directly on the surface of the vessel without the use of a base slip (Table 1: E2; $96 \%$ ) and in one example appears in the assemblage of a mottled yellow-green glaze which extends to the top of the rim. Decoration was not a priority for tripods, but nonetheless appears in the form of a wide shallow groove around the shoulder of the vessel (Pl. III: 10) or a single groove below the rim (Pl. III: 11). The total width of the tripod including the handle shaft ranges from $25-28.5 \mathrm{~cm}$.

\section{Stove tiles}

Stove tiles form only a small component of the ceramic category of the assemblage found in feature 4/09 at Mäsiarska 57/A in Košice (7 accession numbers) and consists primarily of atypical fragments of moulded tiles. The fragments mostly come from the sides of the tile or, more rarely, from the front heating surface. Several of these smaller fragments can be identified on the basis of their mosaic decoration of stylized floral motifs in the form of so-called "wallpaper"-style stove tiles. In one case we find a sequence of unidentified stylized ornamentation in elongated, diamond-shaped fields delineated by areas of S-shaped undulating bands connected by small striped links which alternate with rosettes in the diamonds (Pl. X: 19; similar tiles date from the second half of the $16^{\text {th }}$ and the beginning of the $17^{\text {th }}$ centuries; Brych 2004, Cat. no. 561, 563). In another example we find once again an untreated horizontal stove tile without a base slip with another sequence of incompletely recorded stylized floral decoration of a twin stem with sharp edged leaves and of serrated tree leaves on a field of unknown shape again bordered by ascending bands (Pl. X: 20). A small fragment of a cornice tile rim shows a stretch of flowers or leaves in yellow and green glazes on a white base slip (Pl. X: 17). Possible analogies can be found in the Renaissance-era polychromatic glazed cornice stove tiles with flowers and leaves found at the castle in Parič in Trebišov (Chovanec 2005, 257, fig. F6). An additional fragment of the edge or frame of a tile has a glossy transparent glaze on a white base slip with a marbled effect which is reminiscent of early baroque tilework. Due to the generally poor preservation of the tiles, the key find is a completely reconstructed crown or cornice tile in an open ciborium form with five peaks terminating in "fleur de lis" motifs (Pl. IX: 12; XVII: 7). It is similar in form to tile attachments from the $15^{\text {th }}$ century which have been described by S. Czopek (2005, 70, fig. 7: 7.1.1) and J. Chovanec (2005, 257, fig. F4). The tile is a $1 \mathrm{~cm}$ thick impression and is stabilized by two tongue-like protrusions attached from behind to the unworked surface of the tile.

\section{Ceramic building materials}

Within the collection of ceramic building materials are found several largely unrecognizable fragments of rectangular bricks and a fragment of roofing material. The roofing fragment is part of the lower 
part of a roof tile of "beavertail" shape with a rounded end. On the reverse of the tile there are impressions from the sand moulding and the sides bear slight, almost careless traces of the removal of excess clay after moulding with a wiping tool. The thickness of the tile is $1.7-1.8 \mathrm{~cm}$.

\section{Glassware}

The collection of glassware found during the excavation of feature $4 / 09$ forms a numerous and distinctive element of the total assemblage. Vessels are the predominant form among the twenty two accession numbers although sheet glass also features. Goblets and bottles of various shapes are included in the collection and special mention should be made of the four-sided bottles and the colourfully painted tankards with handles.

\section{Painted bottle}

This object is a four-sided bottle of thick glass. Although the neck is missing, enamelled detail appears to cover almost the entire surface of the bottle. Originally made from clear glass, the surface is now partially opaque and covered with brown corrosion. The bottle is characterized by the rounding of the connecting sides both at the shoulder and at the body which is also connected in an arc to the bottom. The contours of the shoulder are carefully marked with lilac and yellow lines bordered with two lines of white dots. Other lilac and yellow lines are painted around the decorated sections of the body. Stylized floral motifs are painted on three sides of the bottle, three stemmed plants with flowers and leaves or whorls. On the remaining side is a scene of a pelican piercing its breast with its beak to feed three young birds which are craning up to her from the nest with its blood (Pl. XII: 6; XIII). The scene is depicted in white, light brown, yellowish-brown and blue colours. The bottle is reminiscent in shape of another item dated by H. Sedlácková (1998, 73, Cat. 13: 2-15) to the first half of the $17^{\text {th }}$ century.

\section{Painted glass tankard}

This cylindrical tankard with straight sides, a moulded offset base and a large handle was originally made from clear glass with a green tint but is now purplish-brown on the surface and clouded with corrosion (Pl. XII: 5; XIV: 1). Two lines bordered with two lines of dots run around the vessel below the rim. Two enamelled lines run around the vessel above the base which is also decorated with short oblique lines. On the side of the vessel is an enamelled scene which appears to be a depiction of an engagement. It shows two figures, a female on the left and a male to the right, raising their hands together as if gesturing an engagement through, for example, the exchange of rings. Behind and between the two figures we can see stylized depictions of foliage and the year " 1649 " is painted to the sides of the figures (Pl. XIV: 2). The scene is depicted in white and brown colours.

\section{Goblets}

Fragments of goblets are the most commonly found type of glass vessel in the assemblage, with parts of thicker glass being typically found. The fragments are made from clear, probably soda-lime glass with a strong green tint. Air bubbles can be seen in the glass and a layer of cloudy or pearly corrosion appears on the surface. The goblets are comprised of a bowl and a base and both features appear in a variety of shapes. The bowls can be semi-oval, spindle-shaped, barrel-shaped, cylindrical, hexagonal, funnel-shaped, goblet-shaped, open and may be either tall or short. The bases can be bell-shaped (either high or low), solid or hollow. Nine tall hollow bases (Pl. VI: 1-9; XV: 4) are found in the collection with partially preserved sides of the bowl on the basis of which it is possible to suggest that they were largely spindle-shaped (Pl. VI: 17) or also possibly hexagonal. A similar number of low solid bases occur with two (Pl. VI: 10, 11; XV: 1) or three rings (Pl. VI: 12-16, 19; XV: 2, 3, 5) according to which it is possible to imply that the bowls were also spindle-shaped. In addition to these fragments, we can also see a solid tall baluster-style stem on which a semi-oval bowl was likely fitted (Pl. VI: 18). In one case, a wide hollow stem of 
a glass with an original tall cylindrical bowl has survived, imports of which are known from various European locations in the second half of the $17^{\text {th }}$ century (Hulst/Kunicki-Goldfinger 2017, 548, fig. 1). In the case of the goblets it is possible to concur with the findings of Czech researchers that the objects were the products of local glassworks from the end of the $16^{\text {th }}$ century and the first half of the $17^{\text {th }}$ century (Krajic 2007, 78, 79, fig. 16; Sedláčková 1998; Sedláčková et al. 2016; Žegklitz 2007), whilst bearing in mind that the Košice finds would be local Hungarian glass products (Janovčíková 2009, 350). However, the possibility that items in the collection of glassware finds could originate from Tyrolean glass workshops should not be excluded, as these production from this region expanded dramatically in the second half of the $16^{\text {th }}$ century. The significance of Tyrolean glassware was seen in the huge quantities of imported products and was influential in the establishment of other glassworks.

\section{Glass jugs}

Two small fragments of bases with moulded fluting and a deeply concave bottom indicate the presence of small glass jugs (Pl. XII: 4; XIV: 6, 7). These fragments are also made of clear glass with a slight green tint and air bubbles. On the basis of finds from Rimavská Sobota dated to the second half of the $16^{\text {th }}$ century and early $17^{\text {th }}$ century (Botoš 2017, 95-97, fig. 77, 78) and finds from Kroměříz dating to the second half of the $17^{\text {th }}$ century (Sedláčková et al. 2016, 27, fig. 26), these could be hollow spherical products with a cylindrical neck and a strap handle with either a jutting spout on an open mouth or a tubular spout connected to the concave which may have been decorated with fused rings of moulded dashed lines. It is likely that the glass jugs could have had differently shaped mouths, a possibility which is suggested by the large fragment of the probable flagon from clear glass with air bubbles and a greenish tint which has a mouth which is narrowed and almost enclosed to a small flattened knob-like shape (Pl. V: 7; XII: 3). In terms of the fragmentary finds of the lower sections of these small vessels, we cannot exclude the possibility that they may come from glass beer steins with twin angled handles similar to those found in Brno which has been dated to the second half of the $17^{\text {th }}$ century (Sedláčková et al. 2016, 31, fig. 34).

\section{Bottles}

Bottles are the second most common form found in the assemblage of glassware from feature 4/09 and come in a wide range of different types. The fragments of two fluted bottles did not include the necks of the vessels, but they are nonetheless almost complete (Pl. XIV: 3, 4; XV: 7, 8). The first is made from clear glass with a green tint and the second from blue cobalt glass. Based on their similarity to finds from Brno, this glassware can be dated to the second half of the $17^{\text {th }}$ century (Sedláčková et al. 2016, 28, fig. 28). Another form are the thick-sided oval bottles made from purple-black glass (Pl. V: 1, 2; XII: 2). These vessels have a markedly compressed oval body and originally had a tall narrow cylindrical neck. As with the previous bottles, these vessels also have an exact analogue from Brno which has been dated to the end of the $16^{\text {th }}$ and beginning of the $17^{\text {th }}$ centuries (Sedláčková et al. 2016, 26, fig. 23). Another bottle form is the fragment of an approximately spherical vessel from opaque green glass with an elongated, narrow, cylindrical neck, slightly bends at the top, which ends in a somewhat funnel-shaped mouth (Pl. V: 3; XV: 6). This is most likely a Kutrolf-style bottle form such as those which were found in large numbers during archaeological surveys in Bratislava (Sedláčková 2007, 212, fig. 36; 37; Sedláčková et al. 2016, 49, fig. 63a) and Častá (Šimončičová Koóšová 2014, fig. 1: 1-6). The production of bottles with necks formed from several tubes or with twisted necks is known in east Slovakia in the $16^{\text {th }}$ century at the glassworks located in Bardejovská Nová Ves and in the glass workshops of the L'ubovňa estate (Janovč́́ková 2009, 351). A large fragment of the neck and mouth of the back of a flattened bottle comes from a bottle carafe (Pl. V: 8; XII: 1). The vessel has an approximately regular round body with sides decorated with blown glass ribbing. It is made from clear glass with a greenish tint and air bubbles and the surface is affected by brownish corrosion. Corresponding finds from Vienna (Sedláčková et al. 2016, 69, fig. 105), Bohemia and Filakovo Castle (Janovč́ková 2009, 351) have been interpreted as so-called "pilgrim bottles" and dated to the end of the $16^{\text {th }}$ and beginning of the $17^{\text {th }}$ centuries. Given the fragility of the glass, it is more likely that these bottles were used for the storage of alcoholic drinks. Vessels of this type were produced in Venetian glassworks from the end of the $15^{\text {th }}$ century onwards. 


\section{Plate glass}

In addition to the hollow glassware from the examined feature, several fragments of plate glass were also found, from which two clear sheets of disc glass with strengthened cambered edges and a diameter of $10 \mathrm{~cm}$ have been reconstructed (Pl. IX: 13, 14). As with the glassware collection, these windowpanes can be dated from the second half to the end of the $17^{\text {th }}$ century. It is likely that the panes were the product of a local glassworks, but the information we have about the local industry in this period is only fragmentary. In east Slovakia, this may have been the glassworks on the Makovica estate in Bardejovská Nová Ves which is mentioned in 1618 as producing, among other items, "obločné kolečká" or "window discs". Glassworkers also appear in the account books of Bardejov in 1418 and the first mention of glass workshops in the city is made in 1473 (Koóšová 2005, 499). By the $15^{\text {th }}$ century, glass production had also started in the nearby settlement of Šibská Huta on the Hertník estate (Gasper 1969, 144) and also in Stebnícka Huta, Šarbov and Livovská Huta by the $17^{\text {th }}$ century (Frický 1966). From 1595 the Spišská Kapitula glassworks were also in operation in Nižný Medzev (Madziková et al. 2015, 57), and we cannot exclude the possibility that it could have played a role in supplying Košice with glass products. It should also be noted that the first recorded use of glass in Hungary comes from 1307 and is connected to St. Elizabeth's Church (later Cathedral) in Košice (Mészárosová 1983, 128, note 128).

\section{Metal objects}

Various metal objects were found in the infill of feature 4/09. Two coins were recorded, but unfortunately it was not possible to determine their specification. In terms of copper or bronze items, a needle with a simple round eye and approximately fifteen small fragments of copper plate, many of which could be connected together, were also recorded. The fragments were almost certainly parts of a single object, but their state of preservation does not allow us to determine what that original object may have been. The rest of the metal finds from the feature were of iron. The collection of metal objects is comprised of nails (thirty three items) and various fragments of metal strips, some of which have openings for riveting (four items). The collection also includes a wrought eye bolt, a fragment of a horseshoe and three fragments of a shoe sole plate. Also worthy of note are a partially preserved key, a knife blade with a hooked tip (possibly a leatherworking knife?) and also a large piece of iron plate. This last item is an almost complete round plate with a diameter of $12.5 \mathrm{~cm}$ to which a partially preserved continuation of sheet is attached. In the centre of the structure, a strip of metal plate is attached with a rivet, possibly indicating a metal handle. The item may be the remains of the lid of a large cauldron, but other possible interpretations should not be excluded. The finding of a firestone (Pl. XVII: 6) is related to metal strike-a-light (Fröhlich 2018).

\section{EVALUATION OF FINDS}

The significance and value of the assemblage from the survey of feature 4/09 at Mäsiarska 57/A in Košice can be appraised through the most commonly found categories of finds within the collection, ceramics and glass objects. The high feasibility of the physical reconstruction of ceramic and glass objects indicates that the feature had been infilled within a short period. Simultaneously, however, the presence of a significant number of other, predominantly ceramic items suggests that the feature was openly accessible for a longer period of time and had become gradually filled with infill containing these artefacts, several of which can be dated to the late medieval and early modern periods (Table 1: 4, D5). A group of several different types of archaeological finds, including the stove tiles in particular, are associated with this process. These artefacts are found in smaller numbers within the infill of the object and are in a more advanced stage of fragmentation which significantly complicates the assessment of their character and position within the assemblage. The dozens of reconstructed ceramic vessels are of considerable value for the systematic study of post-medieval Košice, although their significance is somewhat limited by the fact that they originate from a single household and cannot therefore provide a more generalized portrait of the Košice urban environment. Nonetheless, they do indicate a step in the right direction given the relative paucity of published collections of early modern period finds in Košice (Dobrová 1988). An overview of the ceramic finds shows that kitchen ware is the predominant category, most commonly clay 
pots and their smaller morphological variants. Other types of kitchenware, specifically lids, cups and tripods also appear in large numbers. These products are also noticeably the work of a single producer. The objects are almost identical in terms of shape and appearance which suggests they were purchased from a local producer, perhaps a member of the Košice potter's guild which had been established in 1514 (Plicková 1996, 11). In 1696, when we assume that the studied feature was undergoing the process of being infilled, five potters are known to have been working in Košice (Špiesz 1972, 94). An overwhelming majority of the ceramic finds were common, utilitarian forms of kitchenware which were essential for every household. These expendable items would be replaced at apparently low cost several times a year, for example at markets or fairs. Weekly markets had been held every Thursday in Košice since the beginning of the $14^{\text {th }}$ century and by the middle of the century two annual fairs were held around the feast days of St. Michael and the Holy Trinity, a number which had grown by a further three fairs on the feast days of St. Elizabeth, the Exaltation of the Holy Cross and the Assumption of the Virgin Mary (Magdoško 2017, 177). The tableware group of the assemblage is represented by jugs, juglets, cups, dishes and bowls. These too are sophisticated works of pottery and it is therefore surprising from the perspective of modern-day archaeological scholarship that these products made from a less commonly used material (white kaolinite clay) are finished in fairly lax manner, a fact which is particularly apparent in several of the dishes and bowls. It is logical that the owners of tableware, the residents of the household, would place a greater significance on these items on the basis of the quality of the finishing and decoration, and it is then possible to assume that this type of product had a longer term role within the household. From the ceramic tableware, it is not possible to find any category which would stand out in terms of its more demanding design or decoration. One possible reason for this is the nature of the environment in which the articles were deposited. Many of the ceramic objects, particularly those of wide form, show signs of the aggressive effect of the environment on the surface resulting in significant degradation of the surface layers including the glaze, slip and even the clay surface itself, which shows evidence of strong abrasion. Given this fact, the presence of two small juglets with blue dye used in their decorative schemes is particularly noteworthy (Pl. IX: 10, 11; X: 6). It is unclear exactly how these two vessels came to be among the accessories of the household at Mäsiarska 57/A. If they are not imported products of foreign origin, then they would be important evidence of the use of this dye in the Košice region, i.e. outwith the context of Habaner pottery, where blue dyes were not typically used until the beginning of the $18^{\text {th }}$ century. We date the backfilling of feature $4 / 09$ and the formation of its valuable assemblage to the end of the $17^{\text {th }}$ century which fully corresponds with the known historical circumstances of the parcel. Nonetheless, on the basis of knowledge about some aspects of technology and of ceramic decoration, it is not possible to exclude the possibility that the process may have continued into the beginning of the $18^{\text {th }}$ century. The majority of the glassware found in the feature is from local Hungarian glassworks which we are unable to identify, but in the absence of written sources we can only speculate that the more well known workshops of east Slovakia were involved; Medzev, Bardejovská Nová Ves and the workshops of the Lubovña estate among others. The domestic origin of the collection is particularly apparent in the case of the goblets and several types of bottle, but note should also be made of the enamelled objects which we assume are of foreign origin. On the basis of more numerous collections of finds from various different social environments (Lesák 2009; Šimončičová Koóšová 2014), it is reasonable to assume that a significant part of the glass vessels found at Mäsiarska 57/A belong among the range of local glass products such as cups and bottles which were already appearing relatively commonly in Hungarian households by the $17^{\text {th }}$ century.

The number of identified ceramic and glass objects in the assemblage also poses a further question. Even after taking into consideration the possibility that feature 4/09 served as a waste pit for a certain period of its existence which would correspond to the regime of gradual filling followed by subsequent emptying and also critically considering the possibility of intrusions in the collection, it is clear that the number of individual types of ceramic and glass vessel found in the feature greatly exceeds the requirements of a typical household. The reconstructed collection of dozens of vessels was accrued within a comparatively short period of time and their archaeologicalization was a relatively fast process. Is it therefore possible that the collection of ceramics and glassware were the possessions of a single household? The fact that the collection includes dozens of duplicates of individual objects casts a shadow of doubt on this possibility as from the perspective of the functional needs of one household this would seem illogical, although the possibility that feature 4/09 may have served as a communal waste site for the use of several households cannot be excluded. The collection of finds can be divided into three distinct groups; firstly, around ninety almost fully reconstructed or reconstructable vessels; secondly 
a layer of dozens of smaller late medieval and early modern sherds in an advanced state of fragmentation which may indicate they are the result of manipulation of the infill of the feature or that they may have entered the feature during the disturbance of the surroundings during the gradual or final infilling of the feature; and thirdly, a large quantity of highly fragmented sherds of baroque ceramics, predominantly of wide-form objects, which have been heavily damaged by fire. This damage could have been caused by the kitchen environment in which they were used but may also suggest an alternative possibility of the dramatic effect of a conflagration and the eventual sudden demise of the household.

\section{PROPERTY OWNERSHIP ON THE STUDIED SITE}

The results of a detailed analysis of the likely property ownership of the site with reference to its wider spatial relationships were published in a 2014 article (Rusnák 2014, 315-317, 355-361) and thanks to this work we can state that life proceeded on two separate parcels of land at Mäsiarska 57/A in the $17^{\text {th }}$ century and that feature 4/09 was part of the southernmost of these two parcels.

Written and cartographical sources offer only limited information about the development of the land at Mäsiarska 57/A in the early and late periods of the early modern age. For the medieval period and also for the $16^{\text {th }}$ century, sources are either completely absent or uncollated. The first known source which mentions the situation at Mäsiarska 57/A is the inspection report from 1603-1604 known as "Relation" which describes the state of six east Slovak towns, with a special focus on Košice (Duchoň 2003; 2013; Krcho 1991; Suchý 1974). This source lists two houses as present on the modern-day parcel $16 / 1$ and also provides us with the names of the owners. The houses are likely those marked as numbers 415 and 414 (from south to north) owned by M. Wadas and G. Madir, respectively (Duchoň 2013, 322, 326; Krcho 1991, App. 35). The inspection report also notes that M. Wadas had been quartering two imperial soldiers and had space for the stabling of three horses. In contrast, G. Madir did not have this requirement and the report points out that his accommodation was narrow. These same owners are recorded on the parcel in 1620, referred to in the register as M. Mattas and G. Mayger (Krcho 1991, D/9). Interestingly, a note beside G. Mayger's name indicates that he has been quartering one imperial soldier, but no such note is added beside M. Mattas's name. The city council register from 1623 shows that the parcel of M. Wadas was now owned by Ch. Süvegos and that of G. Madir by P. Csontos (Krcho 1991, D/9). A source from 1650 records B. Süvegos at the property marked No. 415 in "Relation" and two owners, H. Czibner and D. Rudell at No. 414 (Krcho 1991, D/9). In 1677 we find V. Süvegos as the owner of the first parcel and G. Szabo Tyhani and J. Kovacs as owners of the second, followed in 1691 by M. Polyik and P. Varga (Krcho 1991, C/7). By 1699, however, neither the parcels nor their owners are listed in the registers. The parcel south of Mäsiarska 57/A is mentioned as having been abandoned in 1691 and is not mentioned in 1699 (Krcho 1991, C/7). In the $18^{\text {th }}$ century, the parcel was connected as a garden to the house at Hlavná 100.

\section{KOŠICE IN THE MID $17^{\text {TH }}$ CENTURY}

\section{Economic conditions}

Although Košice had accrued many governmental, administrative and legal functions in the $17^{\text {th }}$ century and was considered the capital of Upper Hungary, from an economic and demographic perspective the city was undergoing a period of marked decline, particularly in comparison with its position in the late medieval period. The Turkish occupation of the Balkans and a considerable part of Hungary had caused an interruption of long-distance trade routes and a general reconfiguration of political and economic activity in central and eastern Europe, a process which had blighted the economic life of the city for many years. The constant threat of war, the still present menace of Turkish aggression and the more immediate power games between the imperial court and the Hungarian estates in which Košice was a common flashpoint did little to improve the stability of the situation. A further destabilizing factor was the ongoing religious struggle between Catholicism and Protestantism. All of these factors meant that while Košice retained its status as a regional centre, the city had long been unable to recover from the economic shocks which it had suffered and was being forced to adapt to circumstances in which its continued prosperity could no longer be ensured. 


\section{Ethnic composition}

The ethnic composition of the population of Košice in the $17^{\text {th }}$ century is not entirely clear, but it is nonetheless possible to perceive several trends and to examine various sources which can allow us to piece together a picture of the ethnic composition of the city in this period. Even at the beginning of the $17^{\text {th }}$ century, in 1601, Péter Pázmány, then only a young Jesuit, could write of the "predominantly German Košice" (Wick 1936, 78). If it is possible to speak of a specific trend, this would be the gradual strengthening of the Hungarian element in the city, primarily at the expense of the German community. The patrician class of the city was still predominantly German, but this was weakening, and the Hungarian population gradually became more firmly established among the lower and middle classes of the city from the middle of the $16^{\text {th }}$ century onwards. This process brought about changes in the economic and manufacturing relations which also gradually became reflected in changes in both ethnic composition and in power dynamics within the city (Granastói 2012, 415; Marečková 1995, 80). The Slovak element is the least well recorded in the written demographic sources for the city despite the fact that there is mention in this period of Slovak preachers, Slovak streets and the mandatory participation of Slovak representatives in the annual election of the city mayor (Uhorský Simplicissimus 1975, 126). Possible reasons for this may be the less developed national consciousness or the sense of amalgamation within the so-called "natio hungarica" felt both by the population itself and by those charged with recordkeeping. By the middle of the $17^{\text {th }}$ century the well-known saying of Ungarischer Simplicissimus that children on the streets of Košice quickly picked up all three languages of Hungarian, German and Slovak was already valid (Uhorský Simplicissimus 1975, 124). J. Duchoň makes the interesting observation in his analysis of "Relation" that the imperial inspectors record the names of property owners in two distinct forms; either in italics, with the Christian name followed by the surname, or in Latin script, with the surname followed by the Christian name (Duchoň 2013, 312, 313). Duchoň justifiably surmises that German-speaking property owners are recorded in the first category and individuals of local "Hungarian" nationality, encompassing both Hungarian and Slovak property owners, are listed in the second category. In percentage terms the two categories are $42.86 \%$ and $50.31 \%$, with the remainder being a combination of the two. Nonetheless, Slovak-sounding names can also be found listed within the first category, ${ }^{1}$ and German (Daniel Lang) or German-sounding names (Greger Pasnanitzer) are listed under the profession of Slovak preacher (Duchoň 2013, 316). Any consideration of the ethnicity of the owners of the parcels at Mäsiarska 57/A in the $17^{\text {th }}$ century is perhaps possible but only with an acknowledgement of the ambiguities involved, and any conclusions must remain provisional. It can be stated, however, that Hungarian-sounding names are prevalent among the list of owners of the property.

\section{Religious dimensions}

The religious situation in Košice in the middle of the $17^{\text {th }}$ century was emerging from a complicated and oftentimes turbulent period which had lasted since the beginning of the century. Over the course of the $16^{\text {th }}$ century, Košice had gradually become an almost exclusively Protestant town, even professing through the auspices of the Confessio Pentapolitana to the Lutheran Augsburg Confession, after which the city entered a new period which was marked by increasing counter-reformation pressure (Škoviera 2009). The gradual conversion of the populace to the Protestant faith did not pass without acts of violence. Attacks on Catholic churches and Church property had been occurring in the towns of Upper Hungary since the 1520s (Rusina 2009, 77) and Košice was not spared unrest of this type. In 1553, an armed mob led by the mayor, Ján Lippai, broke into and looted the Dominican monastery (Wick 1932, 11). The religious atmosphere in Košice was such that after the great fire in 1556, the Dominicans and Franciscans left the city and would not return for many years. The situation only began to be reversed after the fall of Eger to the Turks in 1596, when the Bishopric of Eger was transferred to Košice, at first only formally, joining the Bishops of Oradea and Pécs who had also been forced to flee as war refugees (Harčar 1942, 33). The attempts to bring about a Catholic revival, supported by the highest political powers in the state, the imperial army, the Jesuits and the Catholic Church, were

1 For example, in the case of the widow of M. Hrasskowicz (Relation 2013, 50, Entry 419) or the widow of G. Kowatsch (Relation 2013, 220, Entry 75) 
brought out into the open for the first time in 1603 and 1604 when the Protestant town council was forced by the imperial general Belgioioso to relinquish control of St. Elizabeth's Cathedral. One result of the efforts of Emperor Rudolf II to break the resistance in Košice and the other towns of the Pentapolitana was the inspection report known as "Relation" which was prepared in this period (Duchon 2013; Relation 2013). The significance of this report in identifying the parcel at Mäsiarska 57/A and its owners has been discussed above. The events of 1603 and 1604 triggered several decades of struggle over the religious control of the town, the intensity of which waxed and waned in line with regional and international developments (Bodnárová 2008; Kohútová 2018). While the course of events in the first half of the $17^{\text {th }}$ century was turbulent, it is nonetheless possible to state that Lutheranism was no longer the exclusive faith in Košice and that the positions of both the Catholic Church and also, to some extent, of the Calvinist denomination had strengthened. The small steps of progress despite the occasional setbacks can be observed, for example, in the story of the Jesuit Order and its activities in Košice (Fedorčák 2017). The Jesuits renewed their activities in the town several times over the course of the first half of the $17^{\text {th }}$ century, and this, combined with the return of the Eger Chapter and the Franciscans meant that the Catholic position had put down strong foundations. In Košice and its region, for example, theological polemics in the form of printed dialogues were brought back into circulation, the main figures in which were mainly Košice Jesuits and Lutheran and Calvinist preachers from Košice, Prešov or Sárospatak (Heltai 2007, 43-48). The long efforts of Archbishop P. Pázmány to establish a Jesuit College and Academy were finally realized in 1657 with the founding of the University of Košice. Religious conflicts continued in the city in the second half of the $17^{\text {th }}$ century but the atmosphere and power dynamics had changed, with all sides now either willingly or otherwise accepting the mutual existence of other faiths and their participation in religious affairs.

No information is available on the religious allegiance of the owners of the parcel on which feature $4 / 09$ was found. In this respect, however, potential may lie in more detailed archival research given that the names of the owners in the $17^{\text {th }}$ century have been established. Within the assemblage found in the feature there is only a single object which may provide some answers to this question. One side of the four-sided bottle with enamelled decoration has a depiction of a pelican piercing its breast with its beak to feed three young birds which are craning up to her from the nest with its blood. This emblematic scene has a background with multiple layers of meaning (Bandmann et al. 2015, 90, 91; Daly 2005, 88), but the scene is most typically associated with the Eucharistic motif of the Last Supper or with the Passion of Christ and was thereby used to evoke pious contemplation. This interpretation would not exclude the possibility of any of the Christian denominations practiced in Košice in this period, although the motif of the pelican in $17^{\text {th }}$ century Europe often appears in connection with the activities of the Jesuits and their efforts to renew the Catholic Church. While the bottle and other objects from the feature are by no means enough to allow us to ascertain the religious faith of the residents of the household from which they originate, they are, nonetheless, worthy of attention as the only evidence we have on this issue.

\section{CONCLUSION}

The parcels of land at the modern-day address of Mäsiarska 57/A were situated at the northwest edge of the fortified city in the early modern period, close to where the street of Mäsiarska opened out onto the open space behind the stretch of the city walls known as the Brick Bastion (Fig. 2). A fortified structure known as a cavalier was located inside the walls in this area and there were other military facilities in the vicinity. Therefore, while the parcels were still part of the inner city, they were somewhat on the periphery and in what we would expect to be considered a less attractive residential area. In the northernmost parcel, excavations revealed the foundations of a partially recessed single-halled burgher house with an abutting external staircase (2/09) in addition to a large walled structure (1/10) and two other recessed commercial structures of different wooden constructions $(1 / 09 ; 7 / 10)$ in the rear section of the parcel. These buildings span the occupation period of the site, from the late medieval period to the turn of the $17^{\text {th }}$ and $18^{\text {th }}$ centuries (Rusnák 2014, 354, 355). On the southern parcel a partially revealed section of a walled basement (10/09) was found which may be the remains of a town house. Aligned with this masonry structure, along the northern boundary of the parcel, are two sizable earth features $(7 / 09 ; 8 / 09)$, both of which originate from the same timeframe of the late medieval and early modern periods (Rusnák 2014, 353, 354). Behind the continuation of this alignment we find 
another two smaller, regularly shaped and significantly recessed structures, features 5/09 and 4/09, the latter of which is the focus of this study. Together with the presumed town house and the two earth features $7 / 09$ and $8 / 09$, they represent the occupation of the site from the $15^{\text {th }}$ century to the end of the $17^{\text {th }}$ century. Feature $4 / 09$ had a regular quadratic ground plan and was deeply recessed with wooden posts in the corners and wood-panelling on the sides. It is possible to interpret the structure as a waste pit or possibly as a cesspit. The archaeological data obtained during the investigation was unable to provide sufficient support for the theory that the feature may have served as a cold store. The infill of the feature contained an assemblage comprised primarily of ceramic and glass objects which can help us to form a picture of middle class society in Košice in the early modern period, with a particular focus on the second half of the $17^{\text {th }}$ century. Part of the assemblage can be dated to the late medieval period or the very beginning of the early modern period. The possibility that the waste pit in fact dates back to the turn of the $15^{\text {th }}$ and $16^{\text {th }}$ centuries and was used for a longer period with regular emptying cannot be excluded (Klápště 2002, 130, 193-197), although the fact that the position of the chronologically older elements of the assemblage within the feature did not correspond to the stratigraphy may cast doubt on this possibility; the lowest levels of the feature did not contain only the oldest layer of finds. The finds at the oldest layers were more scattered within the infill and were also markedly more fragmented in contrast to the more complete fragments of ceramics from the $17^{\text {th }}$ century which indicates either the prior manipulation of the feature's infill or that the fragments had found their way into the infill during the gradual or final infilling of the feature. It is also interesting to note that the latest finds, dated more or less to the baroque period, display a higher degree of fire damage which indicates that the end of the occupation of the site at the turn of the $17^{\text {th }}$ and $18^{\text {th }}$ centuries may have come about as a result of a fire. The character of the assemblage corresponds with the opinion expressed above that that the parcel was occupied by a lower middle class household. For the $15^{\text {th }}$ and $16^{\text {th }}$ centuries there is a lack of written sources concerning the occupancy of the parcels and any information must come from the archaeological data. For the $17^{\text {th }}$ century, however, several written sources are available, which, although rather terse, can provide us with a somewhat rounded picture of life on the site. The southern parcel was occupied in the $17^{\text {th }}$ century by the Vadas family and from around the 1620 s by the Süvegos family. The northern parcel saw more frequent changes in ownership over the course of the $17^{\text {th }}$ century. From the first half of the century we know of G. Madir and P. Csontos. By the middle of the century, H. Czibner and D. Rudell are named as owners, followed from the 1670s onwards by G. Szabo Tyhani, J. Kovacs and P. Varga. While surnames alone are not sufficient grounds on which to determine the ethnicity of the property owners, it is possible to note that, with the exception of Czibner and Rudell, the recorded names are Hungarian-sounding, and that this would seem to be the most likely ethnicity for owners of urban middle class households. We know even less about the religious allegiances of the owners, although we can make a very tentative suggestion that the depiction of the pelican feeding its young on one of the glass finds may offer some weak evidence for an inclination towards Catholicism. None of the finds in the assemblage gave any indication of the possible professions of the property owners. 


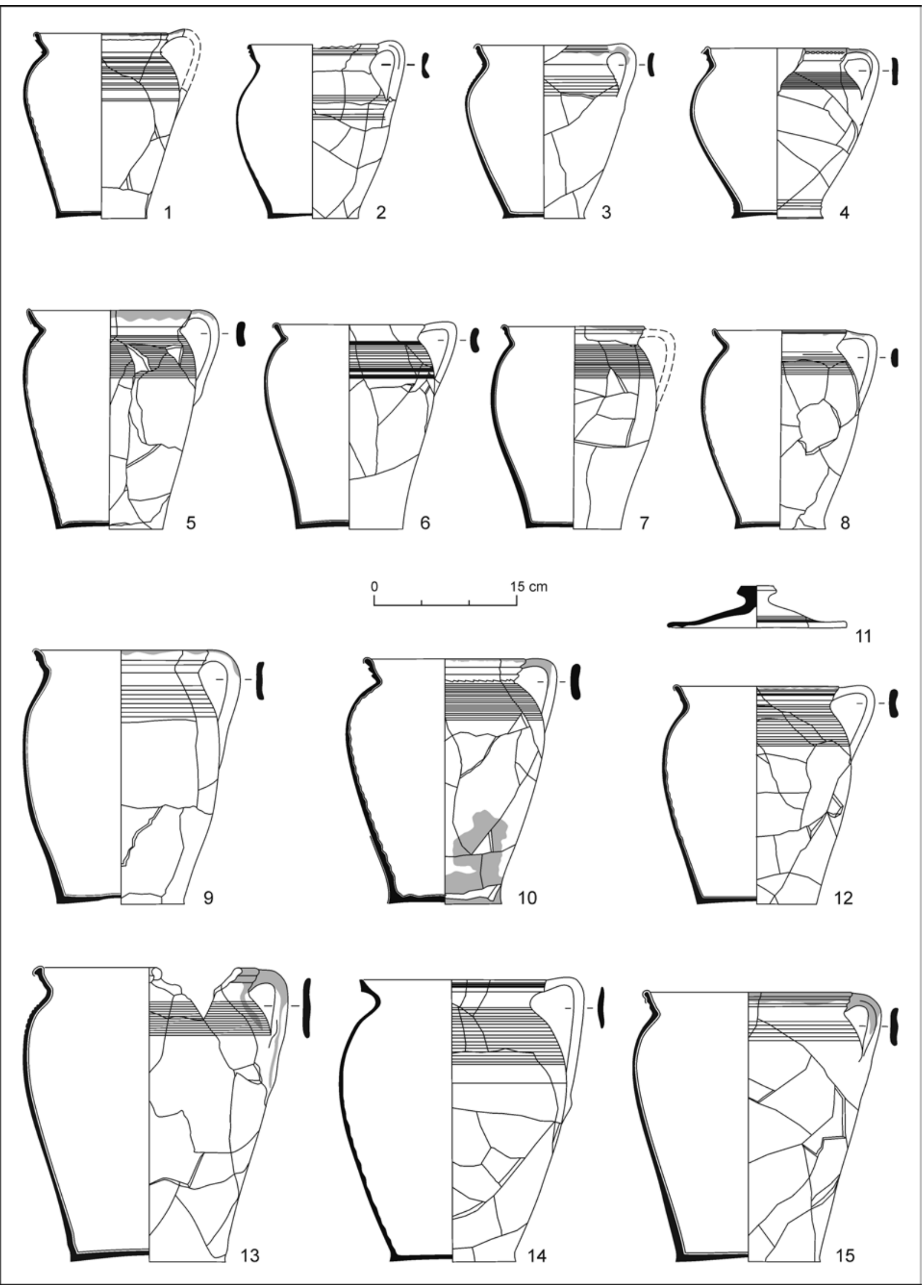

Pl. I. Košice-Mäsiarska 57/A. Clay pots. Illustration M. Volovár. 

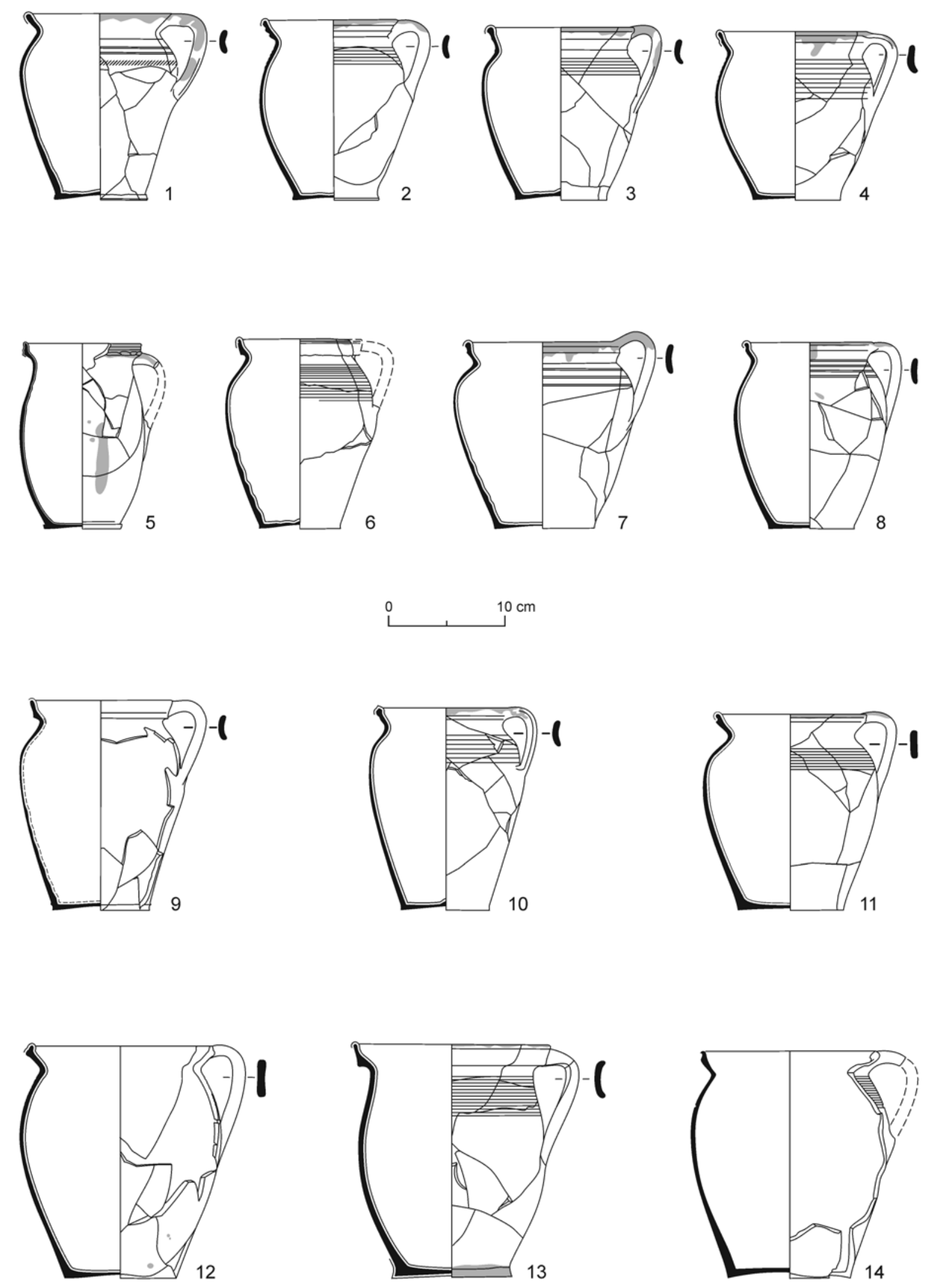

Pl. II. Košice-Mäsiarska 57/A. Clay pots and mugs. Illustration M. Volovár. 


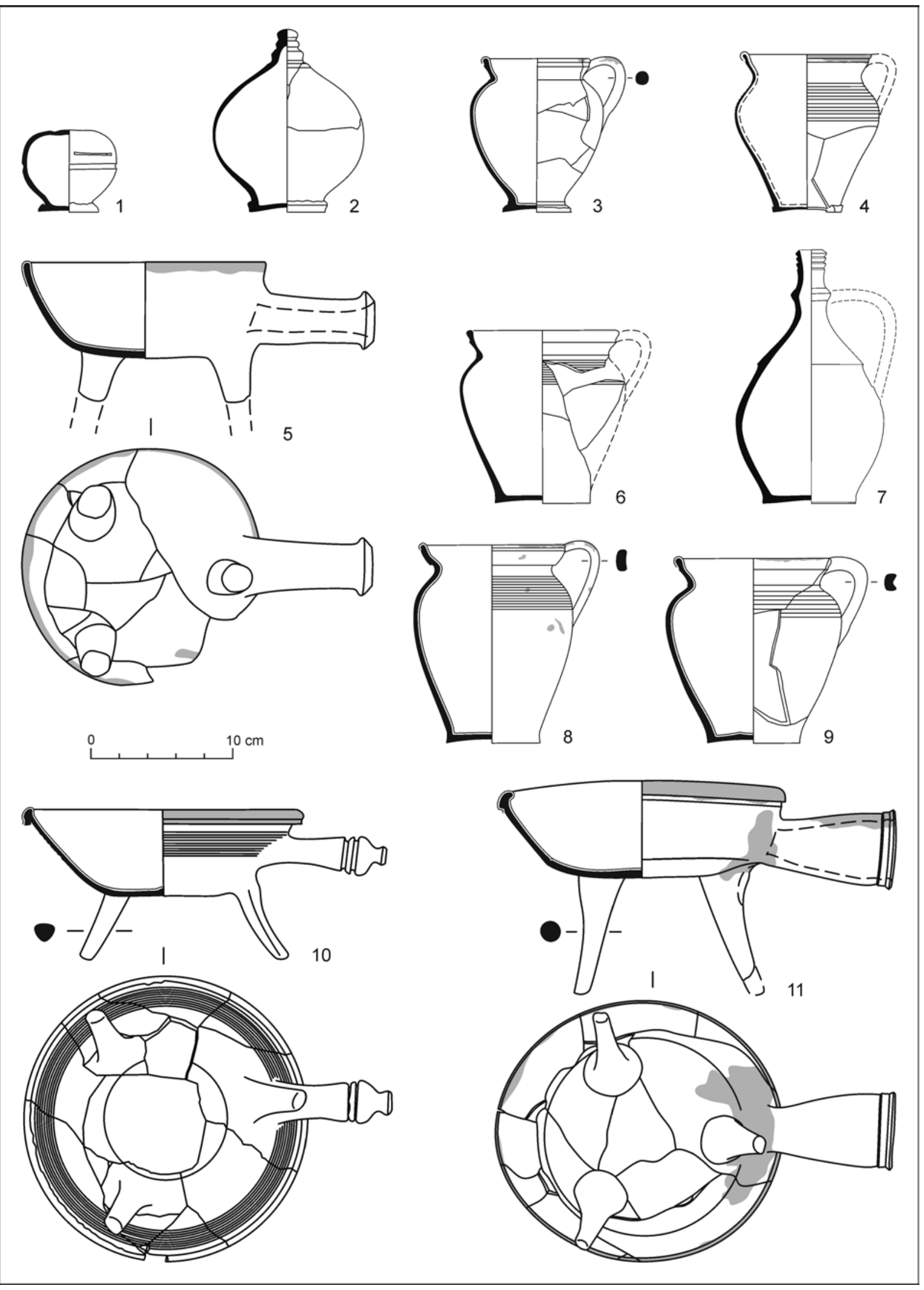

Pl. III. Košice-Mäsiarska 57/A. Mugs, tripods, jug, money boxes. Illustration M. Volovár. 

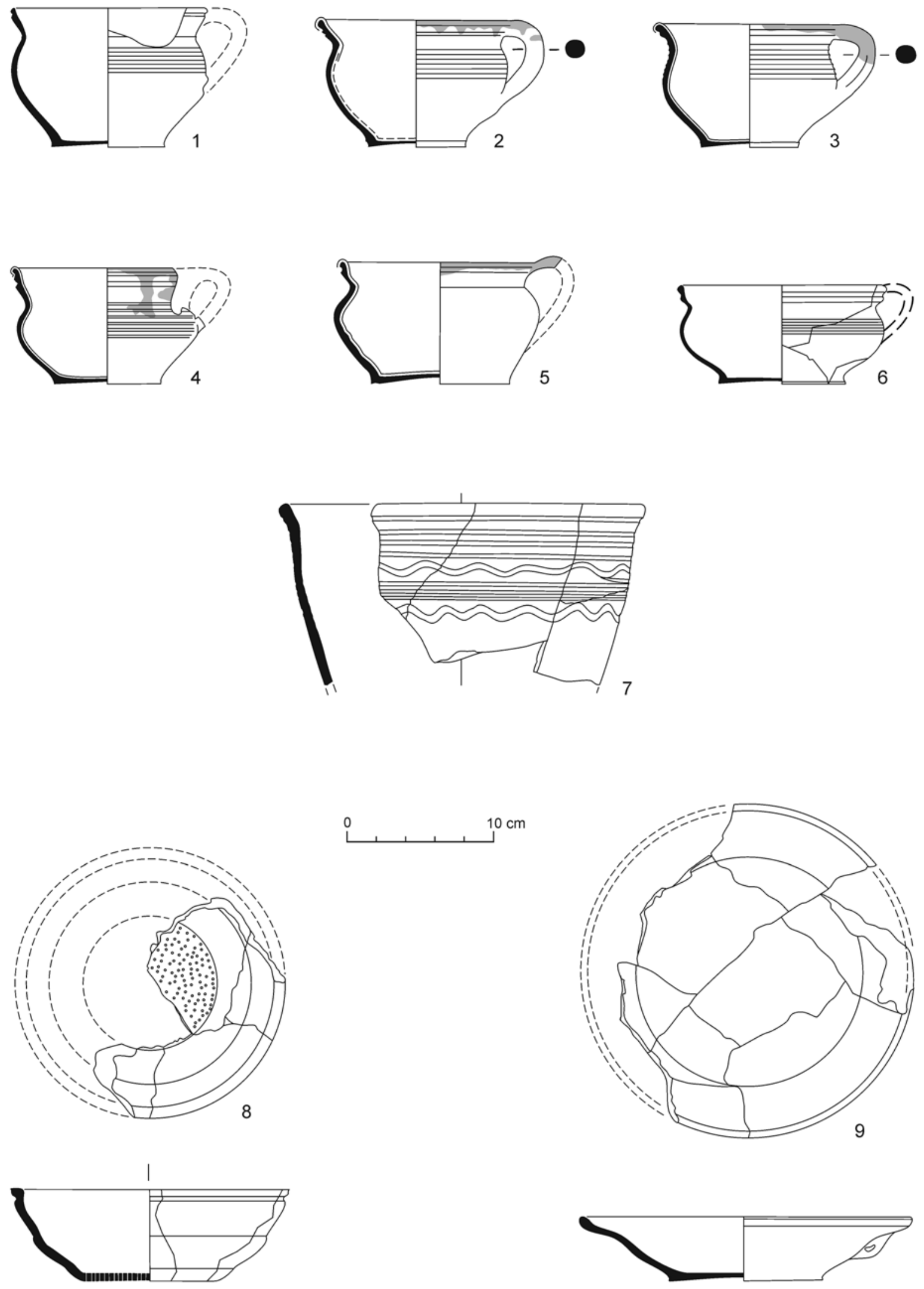

Pl. IV. Košice-Mäsiarska 57/A. Cups, bowls, colander. Illustration M. Volovár. 


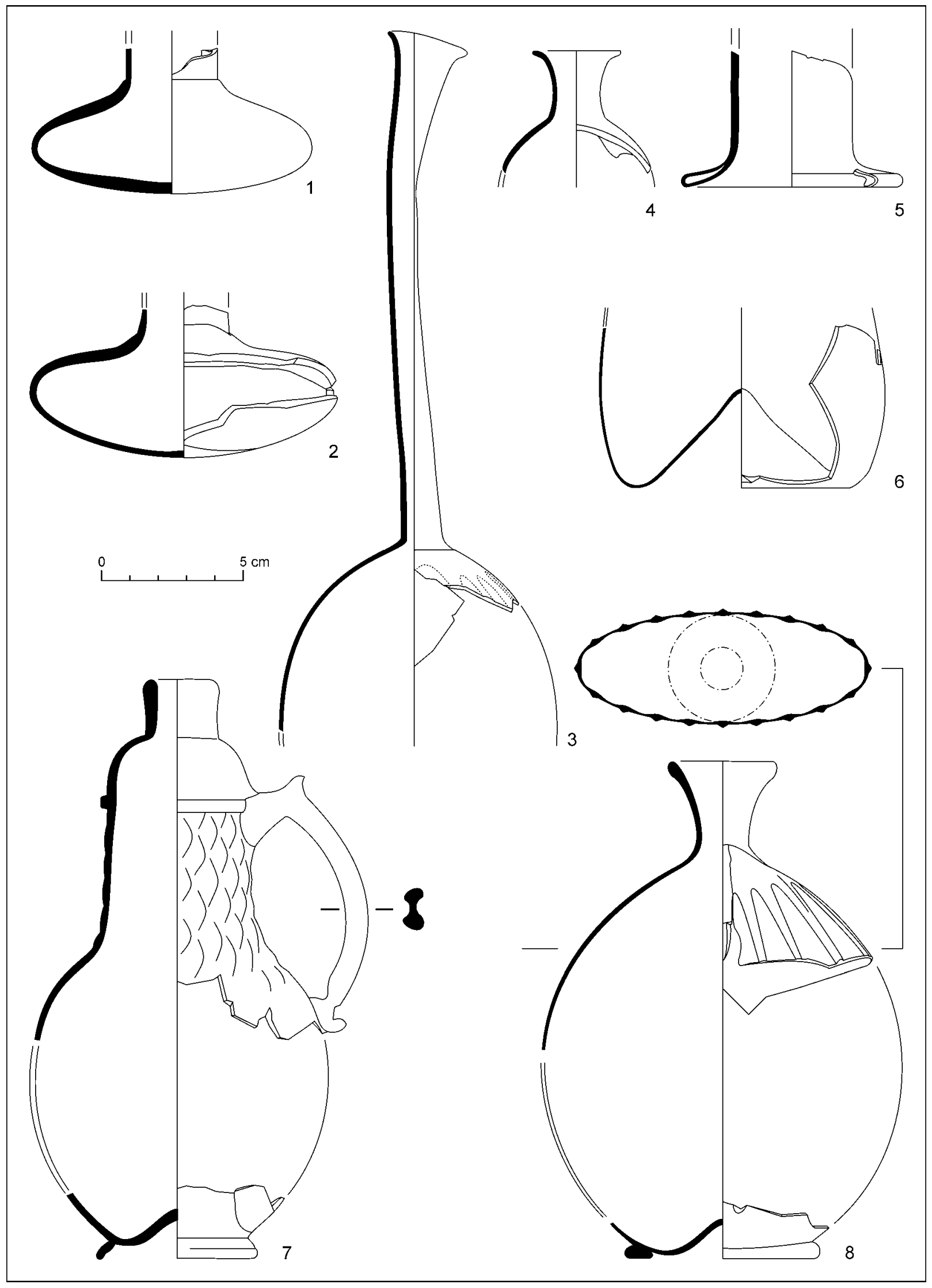

Pl. V. Košice-Mäsiarska 57/A. Bottles, vials, carafe, glass beaker. Illustration M. Volovár. 

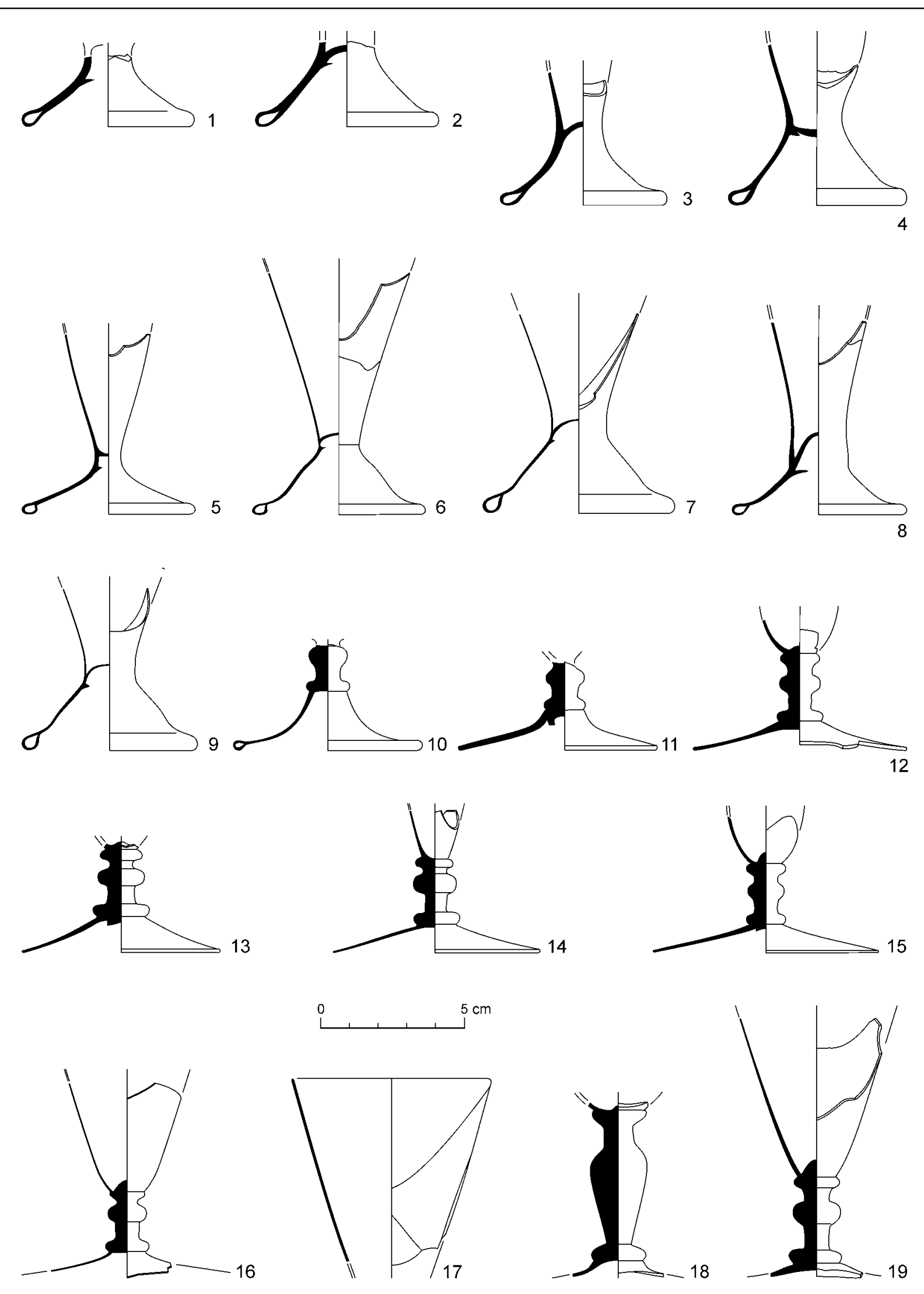

Pl. VI. Košice-Mäsiarska 57/A. Goblets - glass. Illustration M. Volovár. 


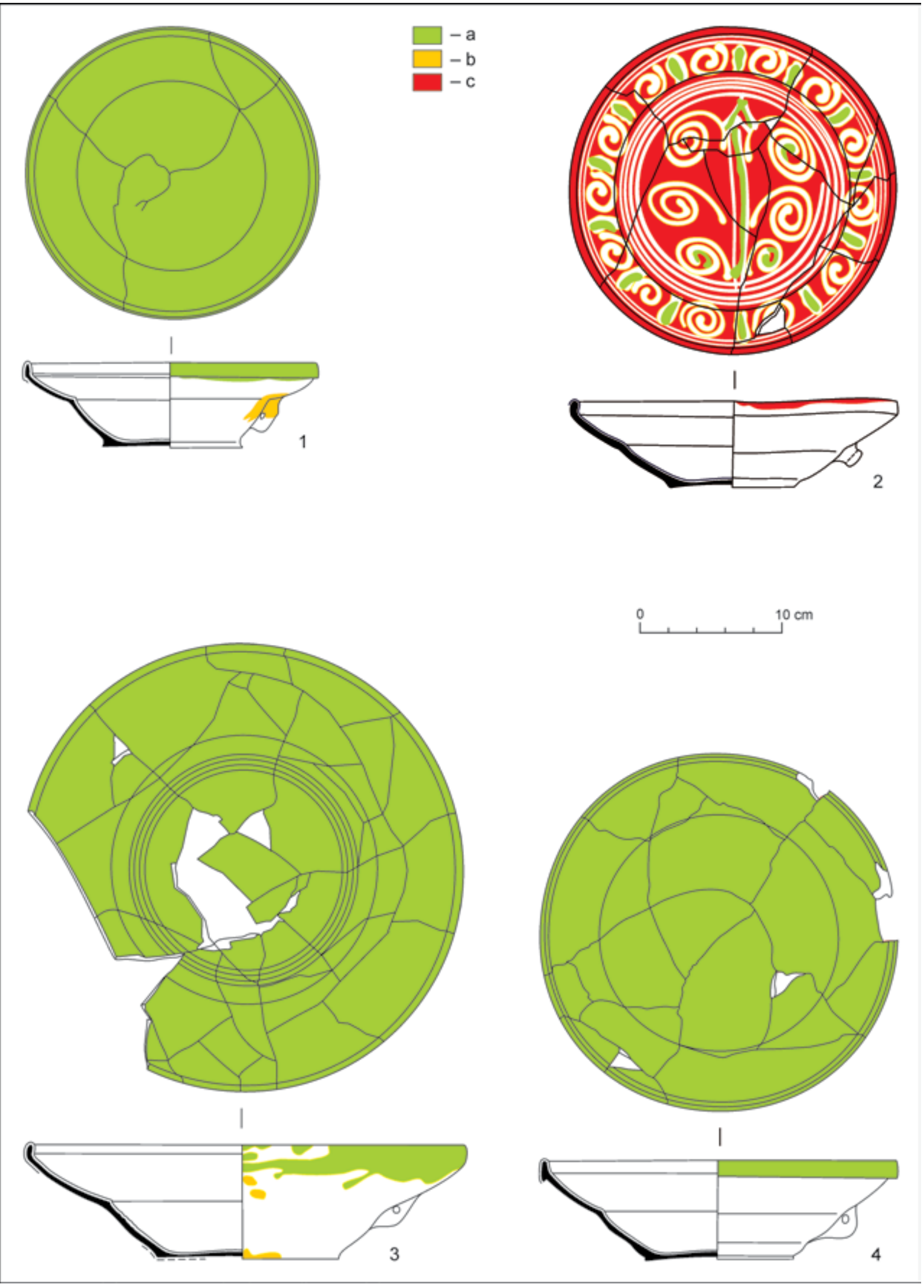

Pl. VII. Košice-Mäsiarska 57/A. Bowls. Illustration M. Volovár. Color scheme: a - green; b - yellow-brown; c - dark red. 


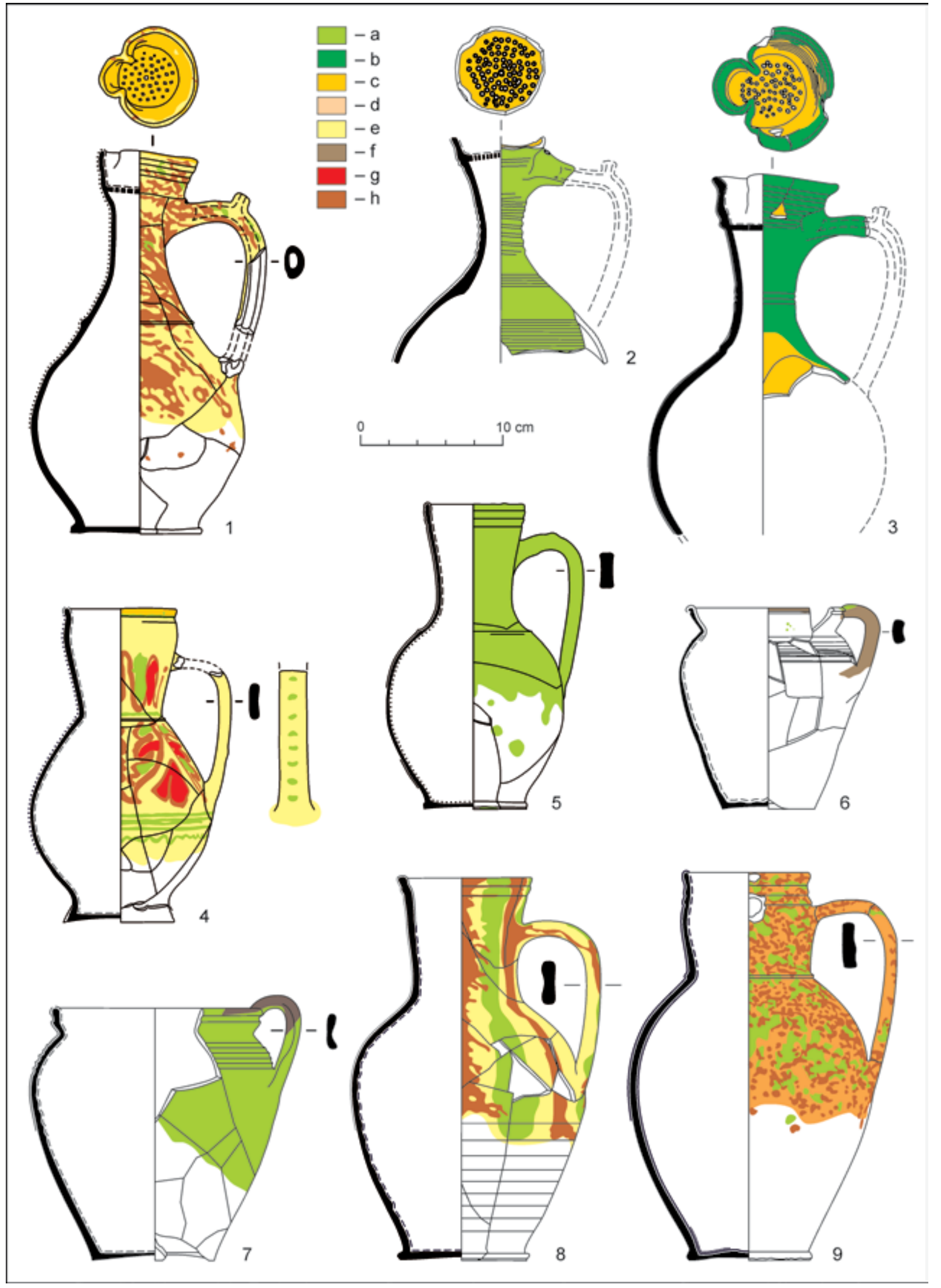

Pl. VIII. Košice-Mäsiarska 57/A. Jugs, mugs. Illustration M. Volovár. Color scheme: a - green; b - dark green; c, d - yellow-brown; e, f - yellow; g - dark red; h-brown. 

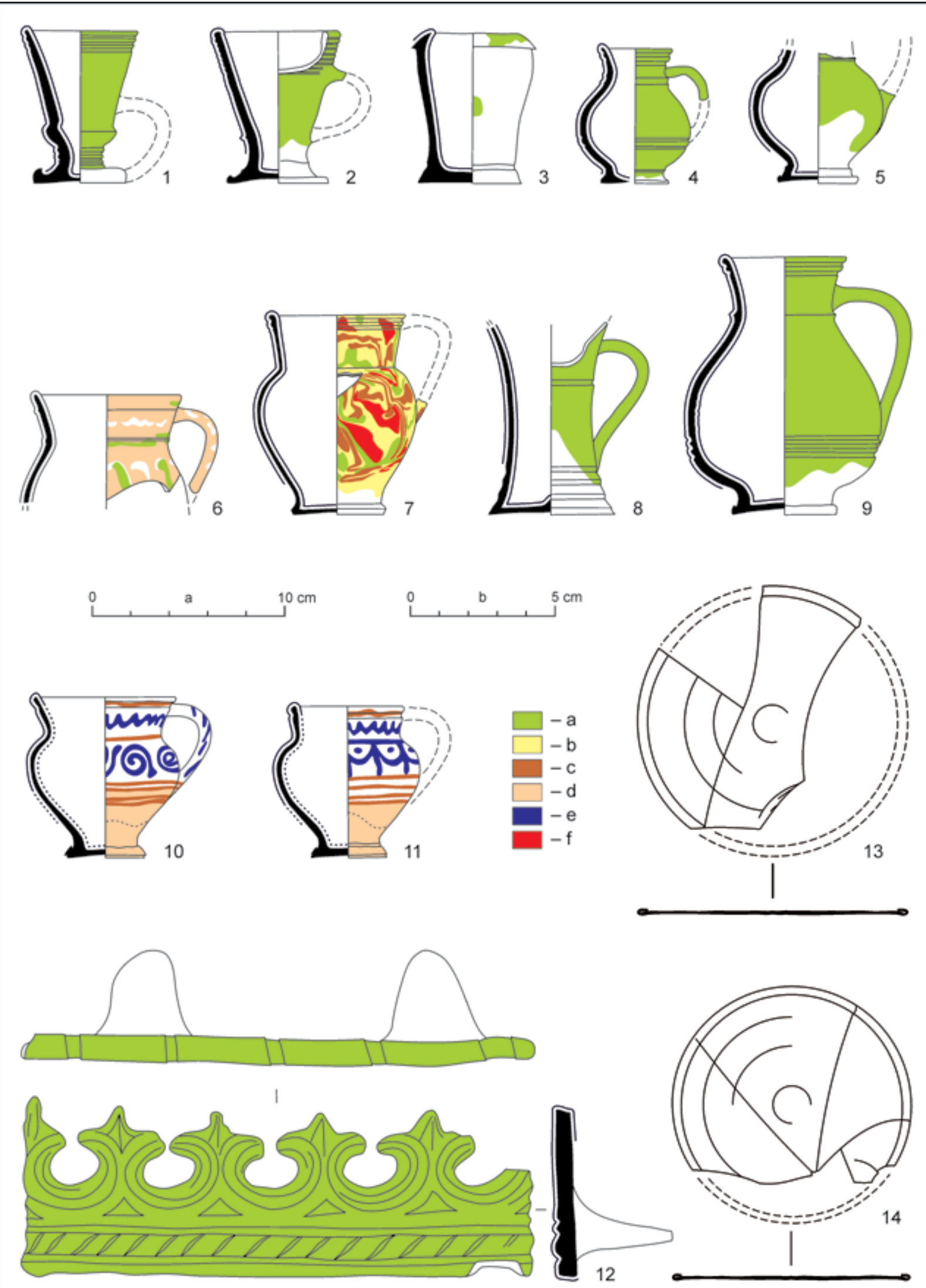

Pl. IX. Košice-Mäsiarska 57/A. Beakers, juglets, jugs, stove tile. Glass window pane. Illustration M. Volovár. Scale: $\mathrm{a}-1-12 ; \mathrm{b}-13$, 14. Color scheme: $\mathrm{a}$ - green; $\mathrm{b}$ - yellow-brown; $\mathrm{c}$ - brown; $\mathrm{d}$ - yellow; e - blue; $\mathrm{f}$ - dark red. 


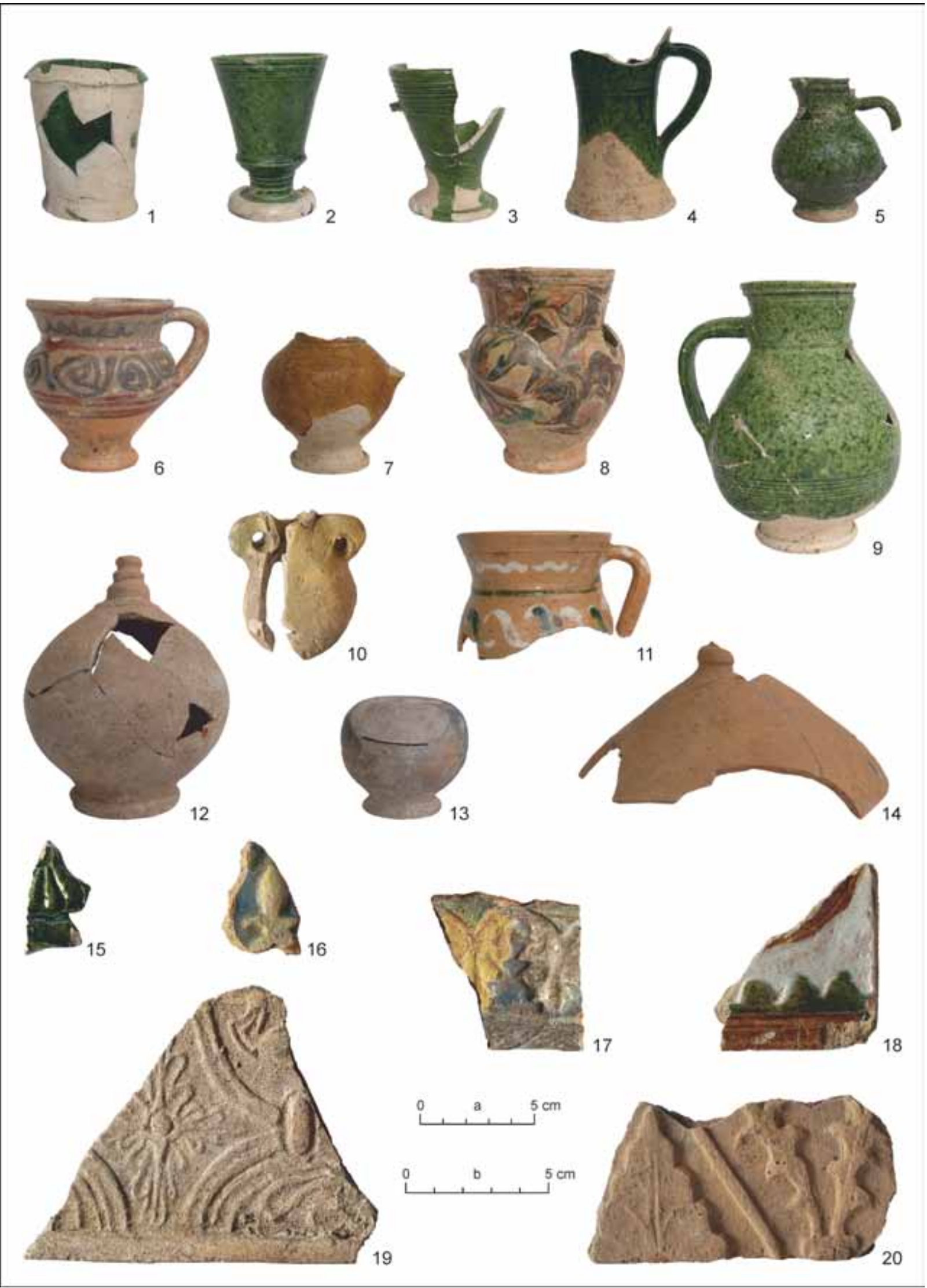

Pl. X. Košice-Mäsiarska 57/A. Beakers, juglets, money boxes, miniature vessel, stove tiles. Photo M. Čurný (10, 15-20), R. Rusnák (1-9, 11-14). Scale: a - 1-13; b-14-20. 


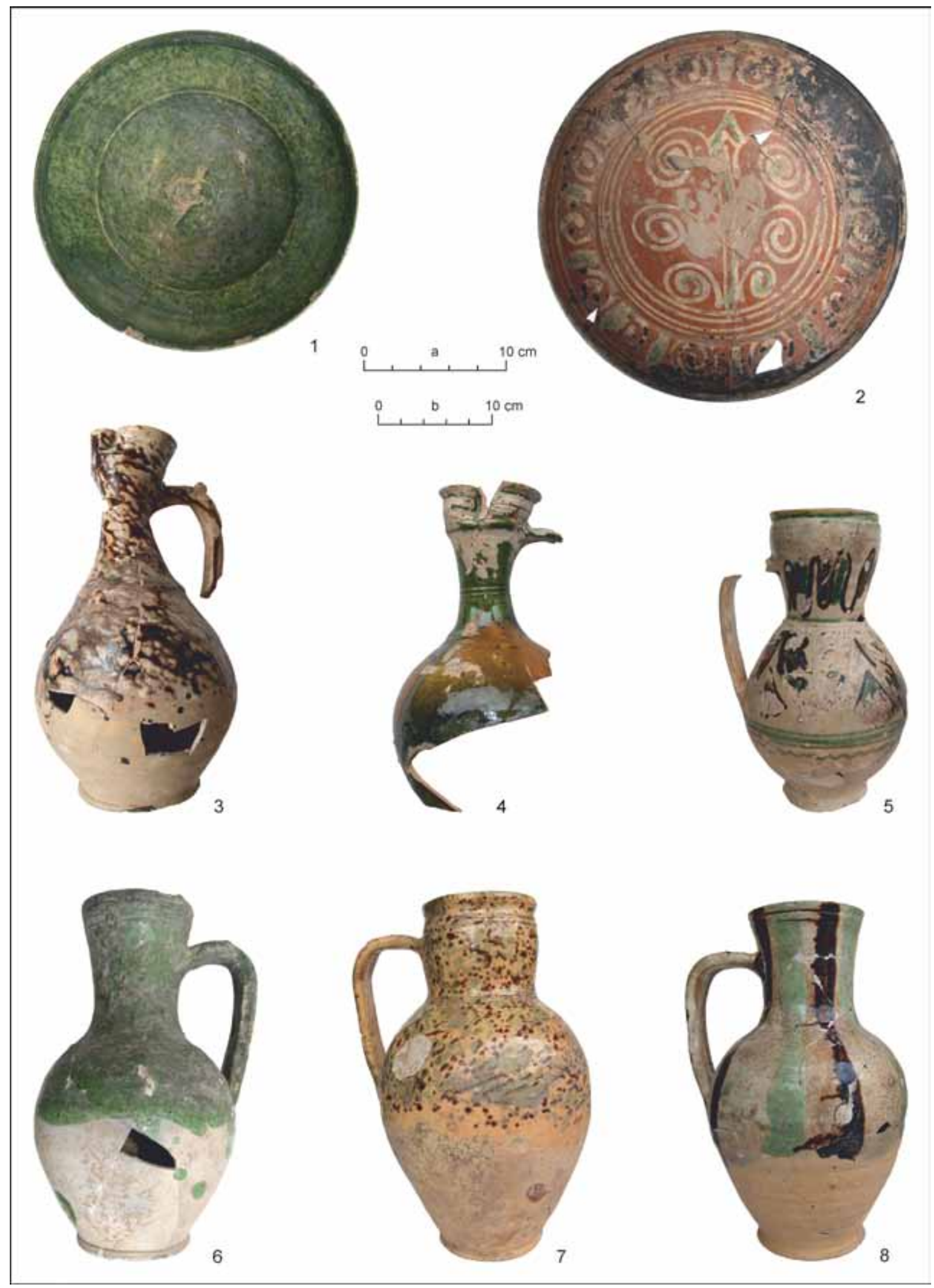

Pl. XI. Košice-Mäsiarska 57/A. Bowls, jugs. Photo R. Rusnák. Scale: a - 1, 2, 5-8; b - 3, 4. 

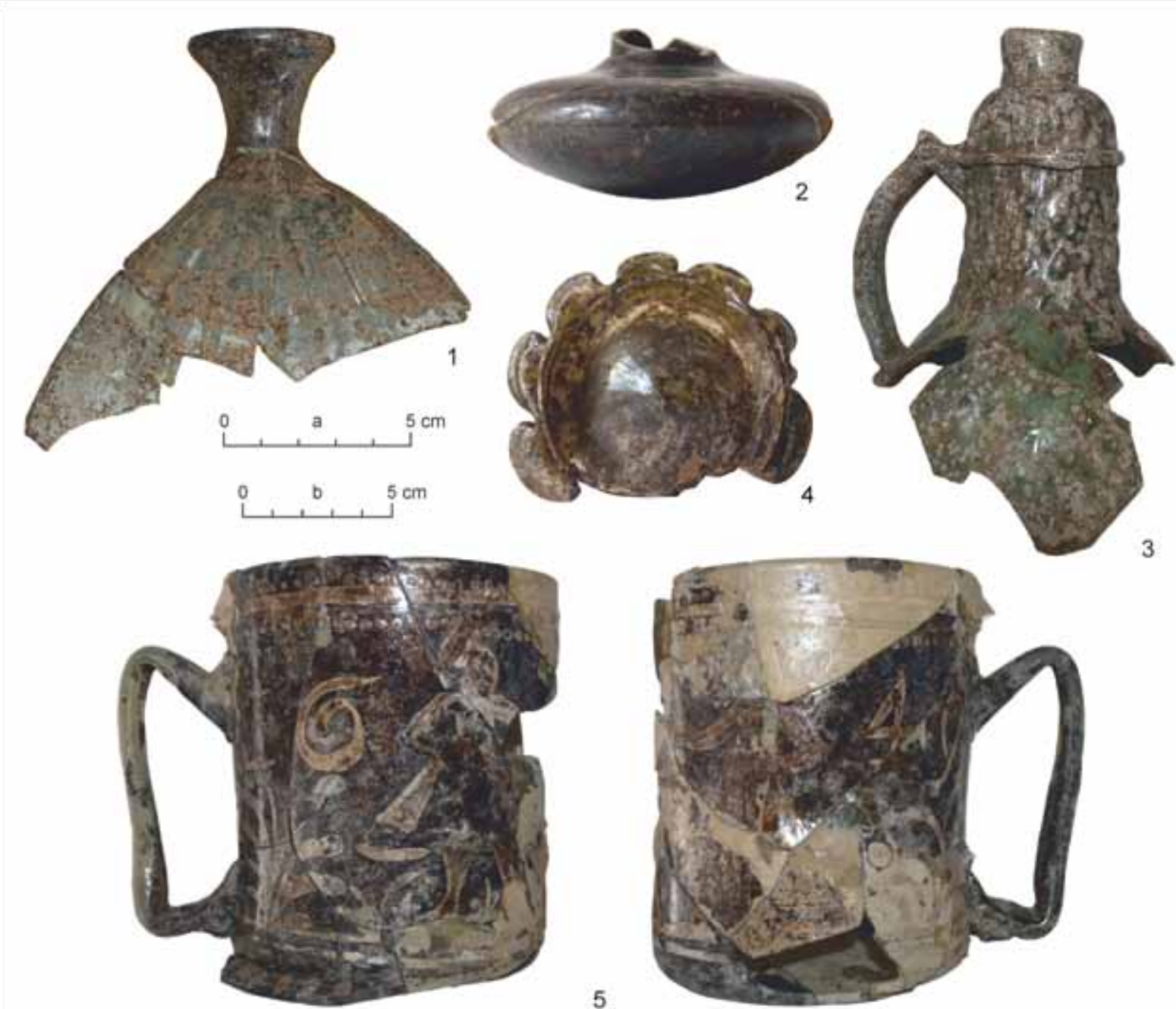

5
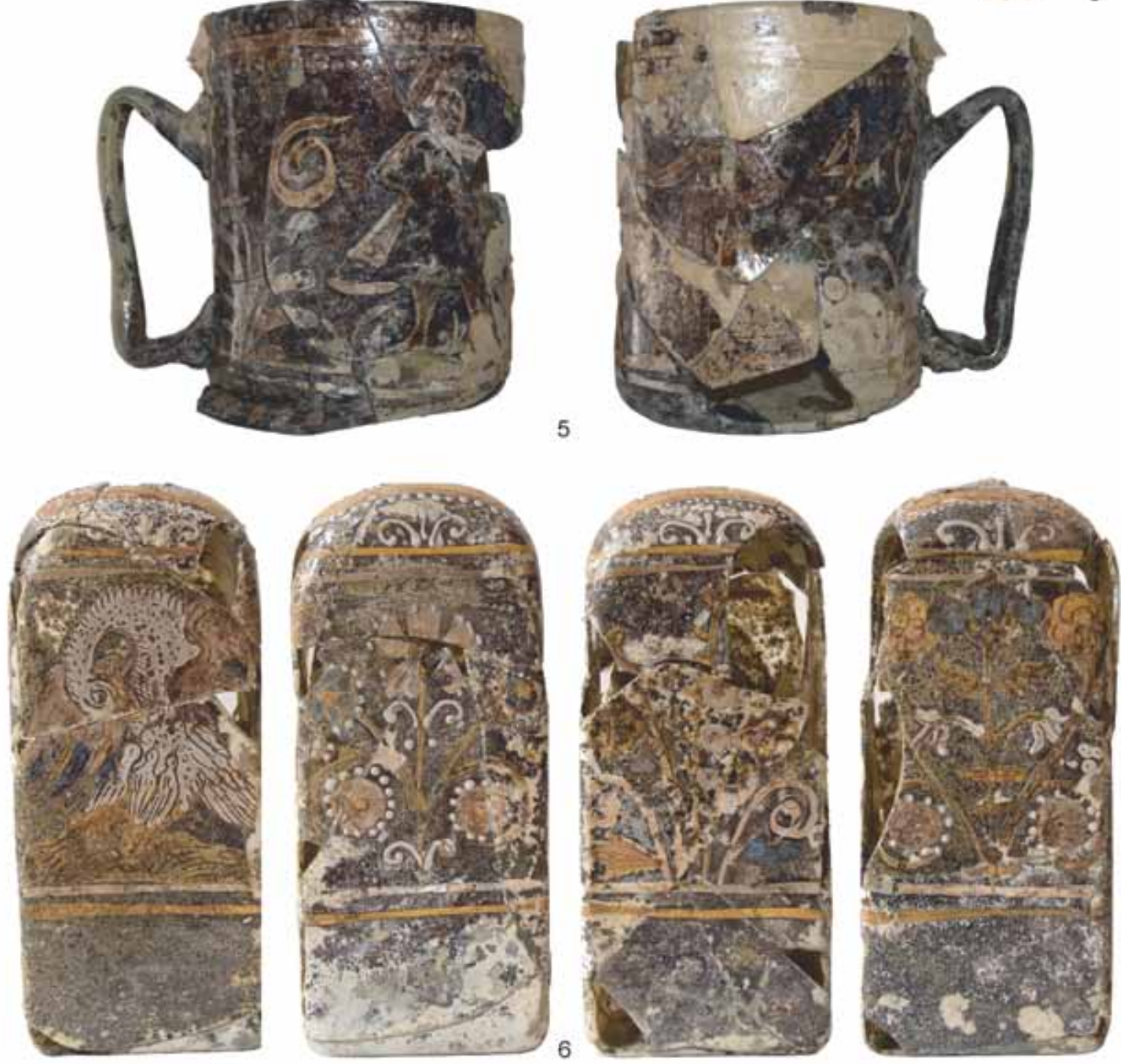

Pl. XII. Košice-Mäsiarska 57/A. Glassware: bottles, jugs, tankard. Photo R. Rusnák. Scale: a - 1, 4; b - 2, 3, 5, 6. 


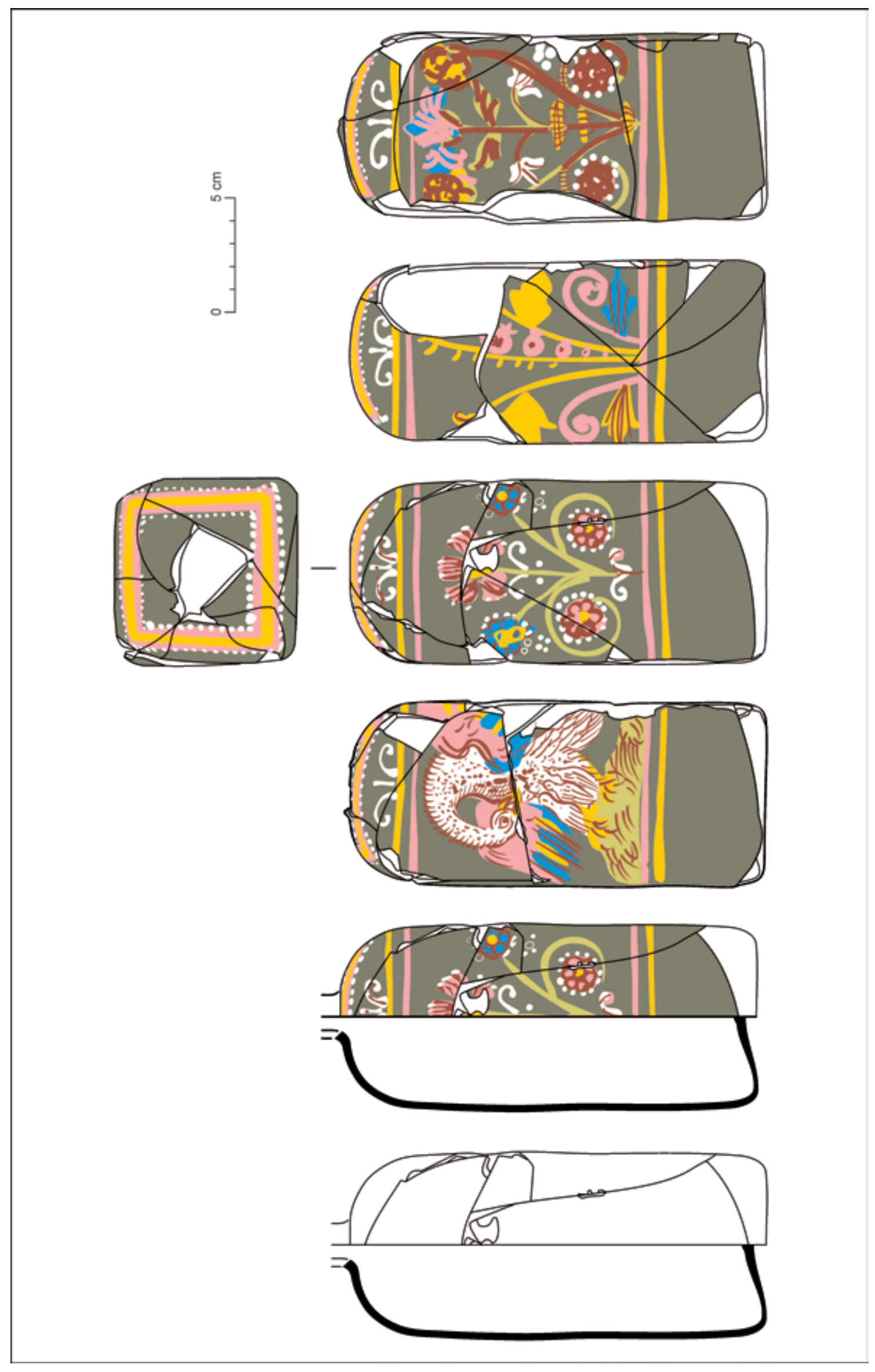

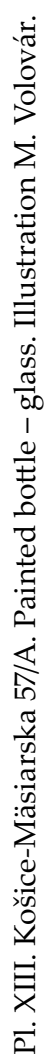




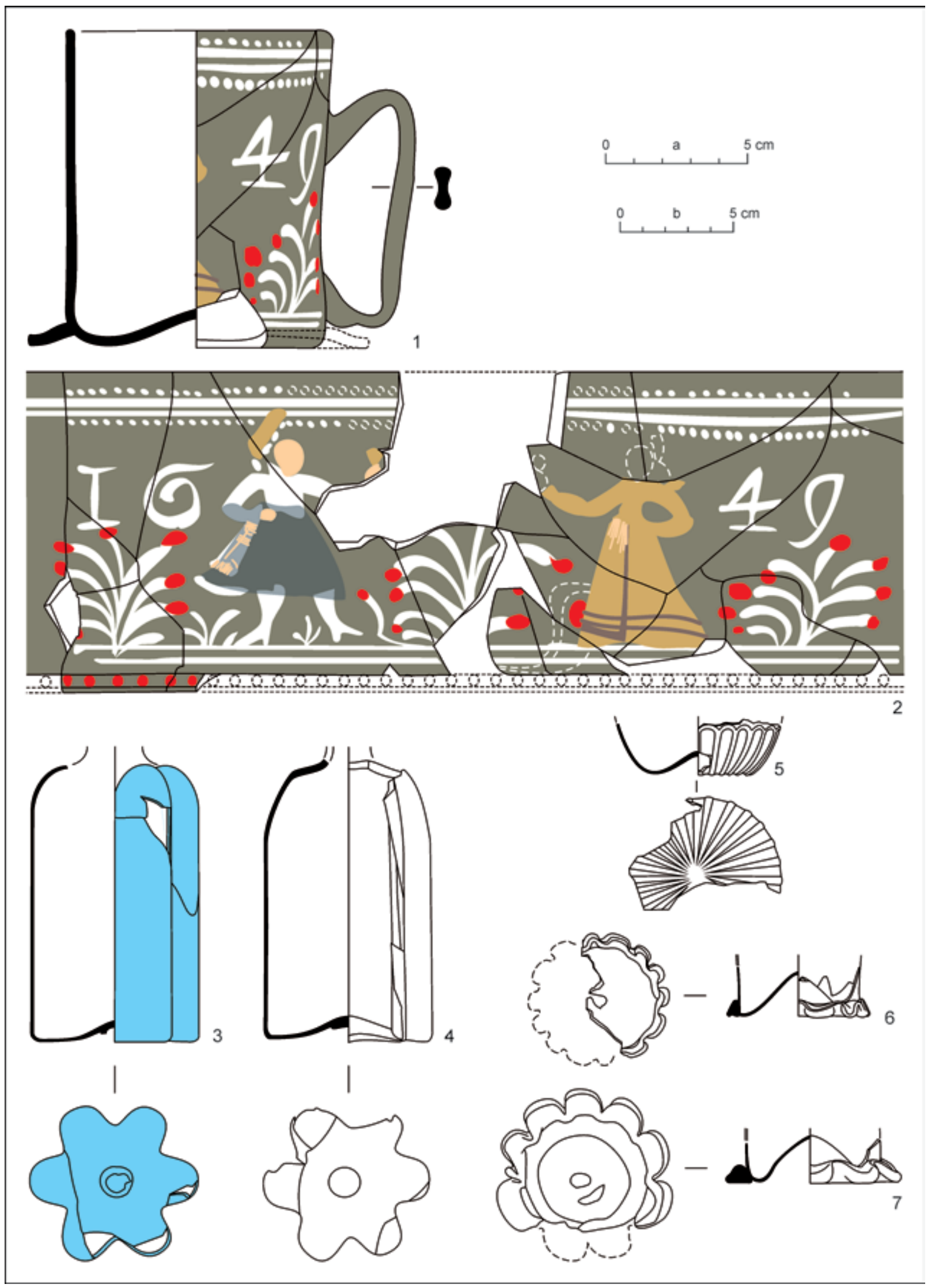

Pl. XIV. Košice-Mäsiarska 57/A. Bottles, jugs, tankard - glass. Illustration M. Volovár. Scale: a - 1-4; b-5-7. 


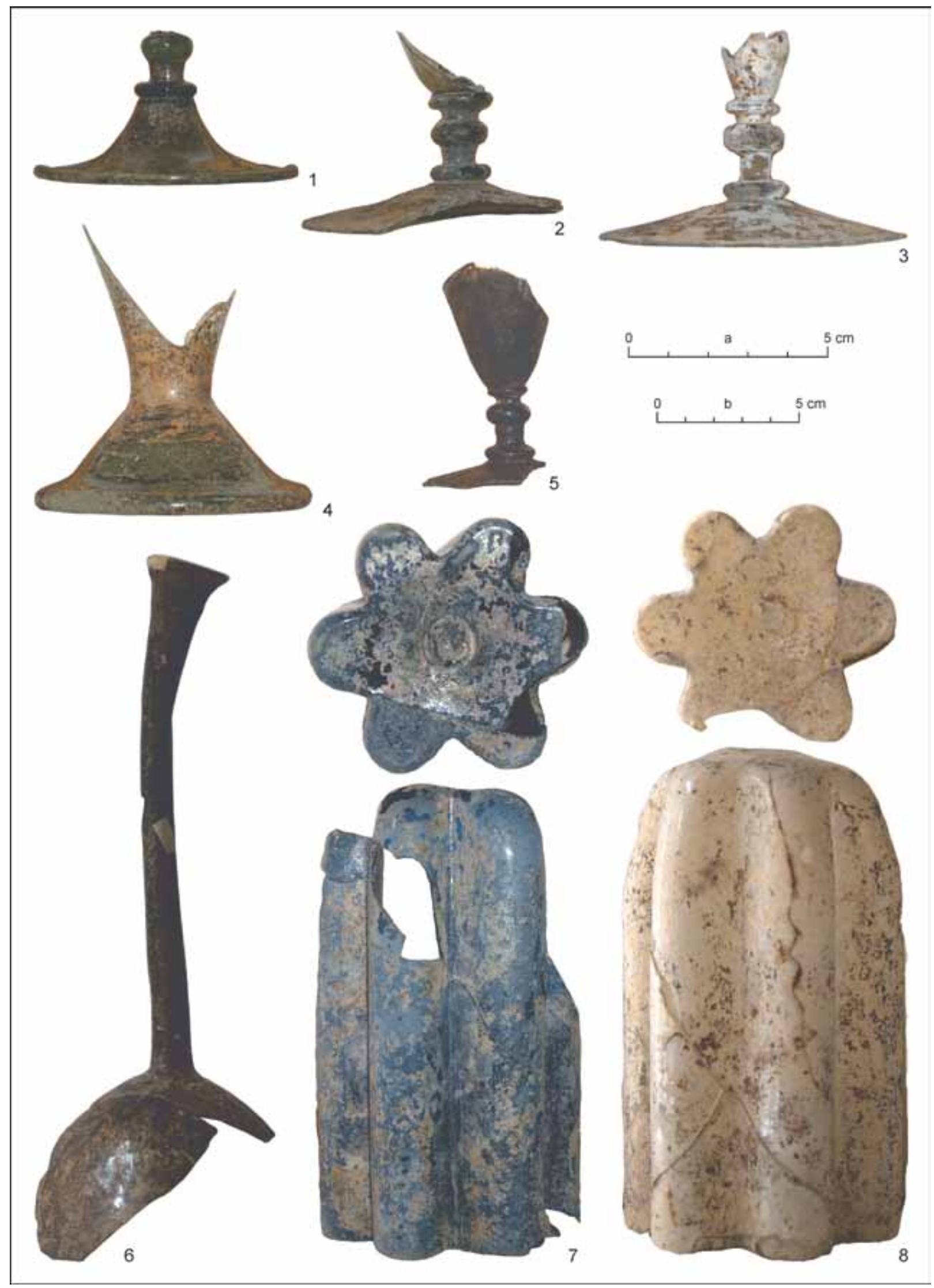

Pl. XV. Košice-Mäsiarska 57/A. Goblets, bottles - glass. Photo R. Rusnák. Scale: a -1-5, 7, 8; b - 6 . 


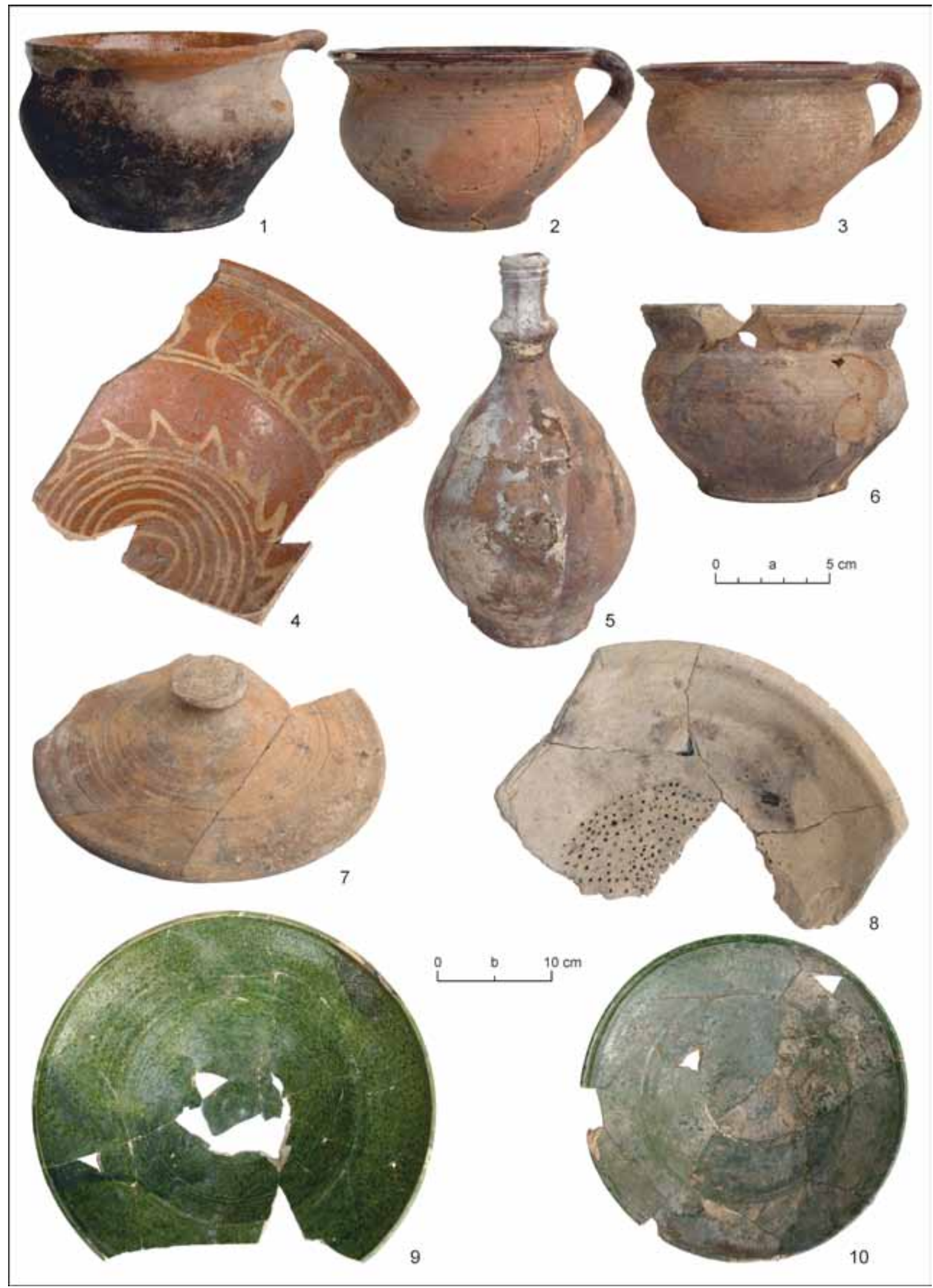

Pl. XVI. Košice-Mäsiarska 57/A. Cups, jug, bowls, colander, lid. Photo R. Rusnák. Scale: a -1-8; b - 9, 10. 


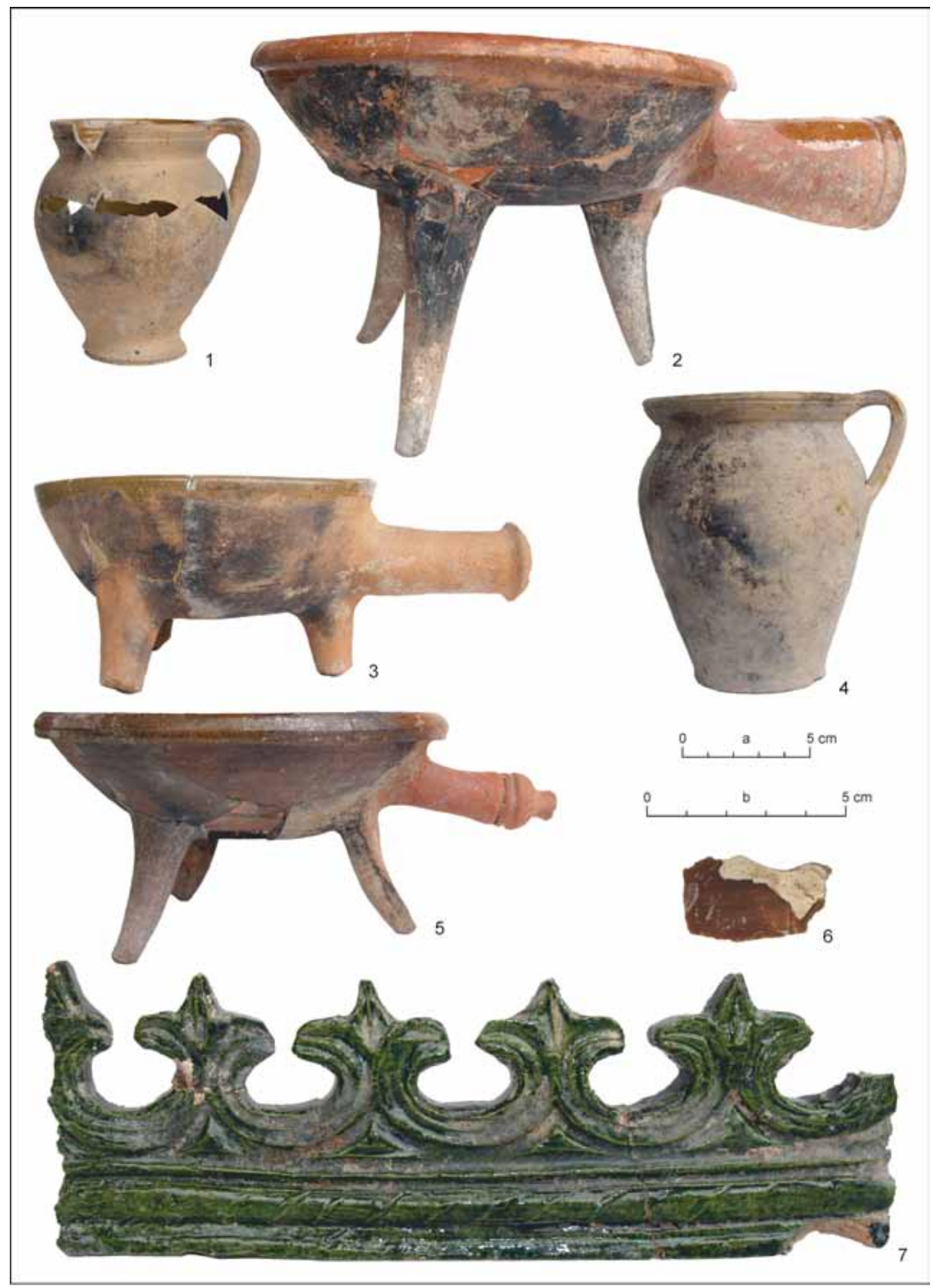

Pl. XVII. Košice-Mäsiarska 57/A. Mugs, tripods, stove tile, firestone. Photo R. Rusnák. Scale: a - 1-5; b - 6, 7. 

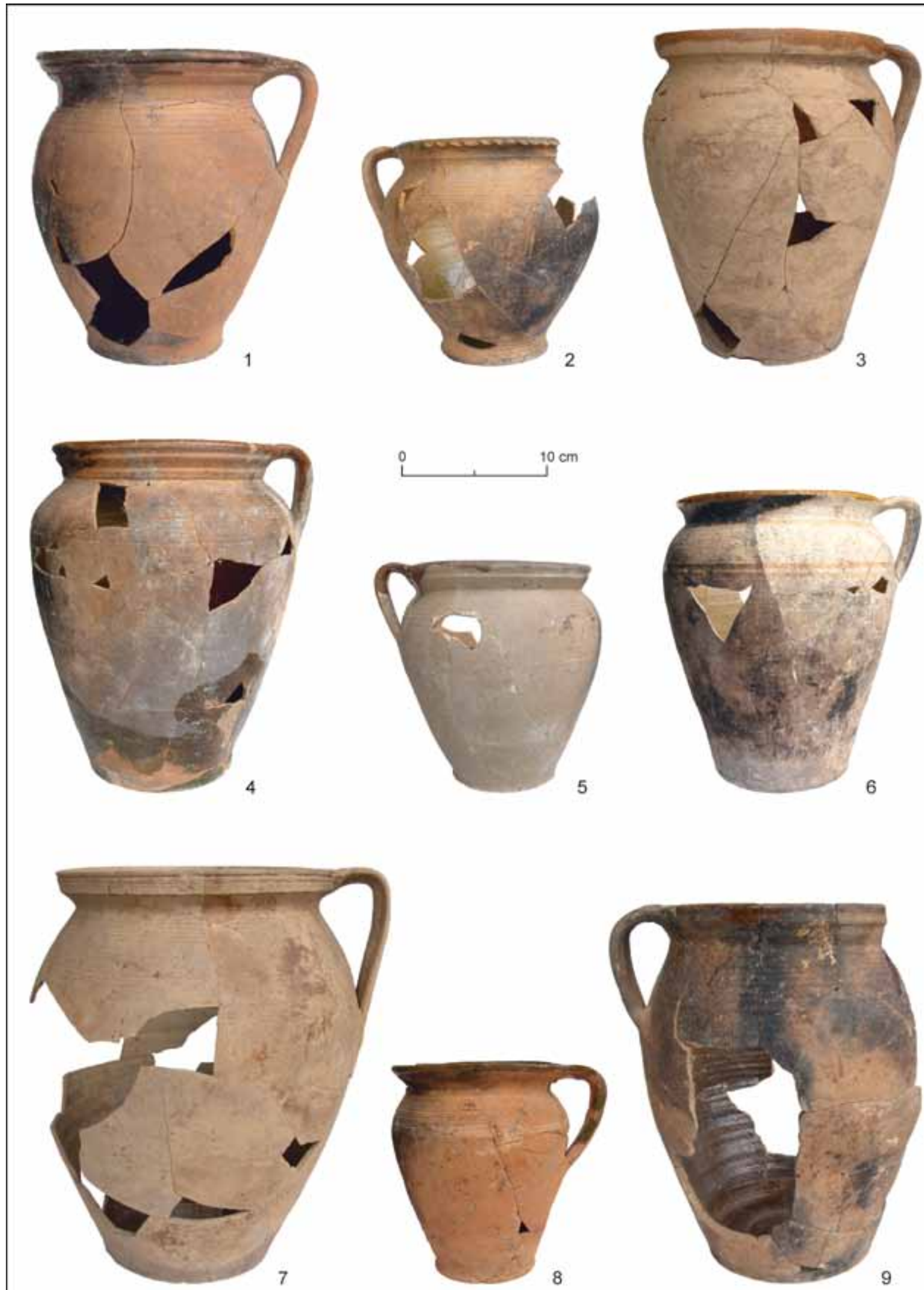

Pl. XVIII. Košice-Mäsiarska 57/A. Clay pots. Photo R. Rusnák. 


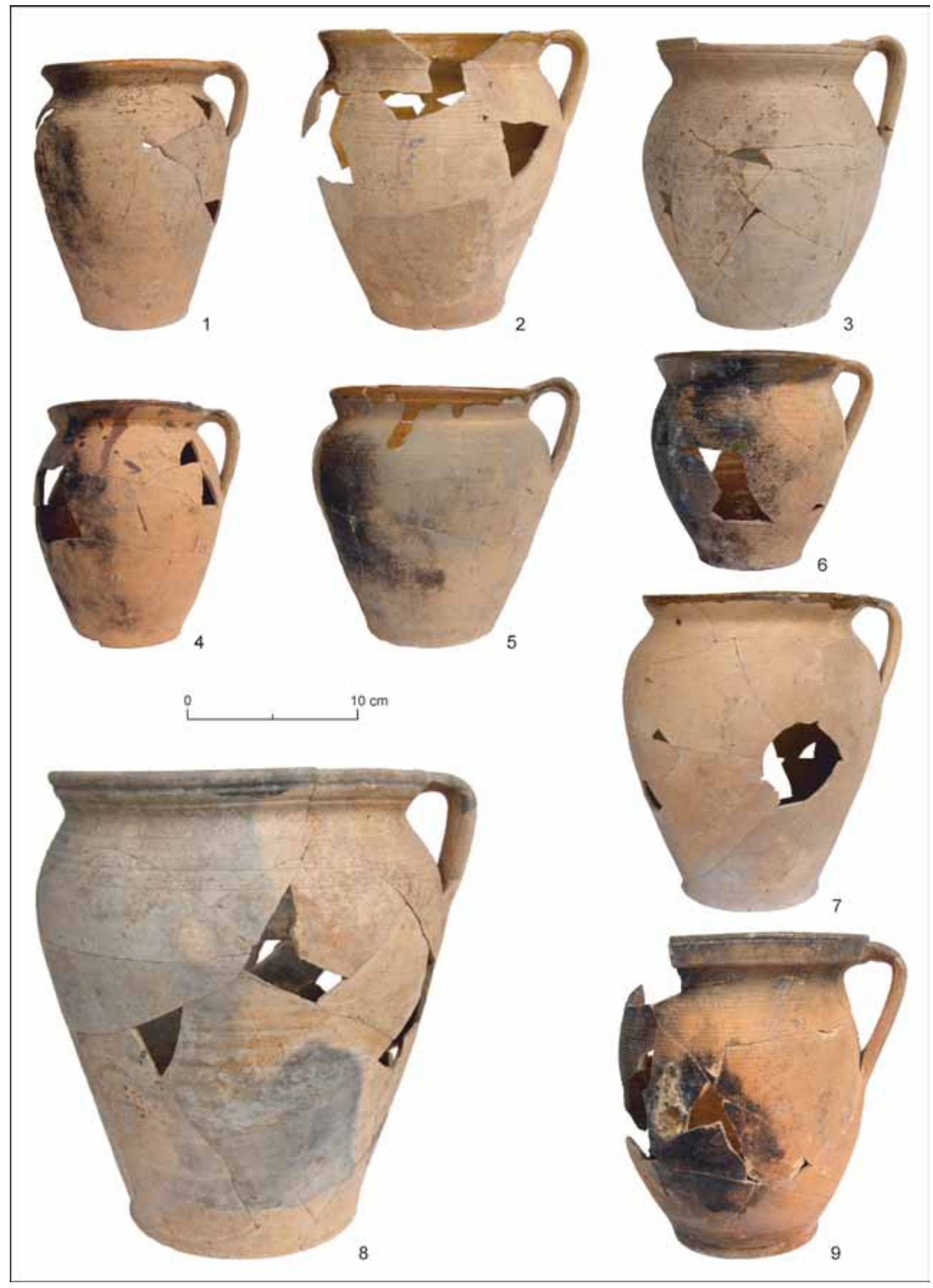

Pl. XIX. Košice-Mäsiarska 57/A. Clay pots. Photo R. Rusnák. 


\section{BIBLIOGRAPHY AND SOURCES}

Bandmann et al. 2015

Bodnárová 2008

Botoš 2017

Brych 2004

Czopek 2005

Čaplovič 1990

Daly 2005

Dobrová 1988

Duchoň 2003

Duchoň 2013

Ďurišová/Uličný 1999

Fedorčák 2017

Frický 1966

Frolík/Kozáková/Musil 2018

Fröhlich 2018

Gasper 1969

Gašaj 2015

Granastói 2012

Harčar 1942

Haruštiak/Roth/Vereščáková 2012

Heltai 2007

Horvat 1999

Hulst/Kunicki-Goldfinger 2017

Chovanec 2005

Janovčíková 2009

Klápště 2002
G. Bandmann/W. Braunfels/J. Kollwitz/W. Mrazek/A. A. Schmid/H. Schnell: Lexikon der christlichen Ikonographie. Freiburg im Breisgau 2015.

M. Bodnárová: Protihabsburské povstania a vývin konfesionálnych pomerov na Slovensku v prvej polovici 17. storočia. In: Š. Šutaj (ed.): Protihabsburské stavovské povstania a ich vplyv na vývoj pohraničných regiónov Slovenska a Mad'arska $v$ 17. storočí. Prešov 2008, 136-143.

A. Botoš: Rimavská Sobota vo svetle archeológie a archeologických nálezov. Rimavská Sobota 2017.

V. Brych: Kachle doby gotické, renesanční a raně barokní. Výběrový katalog Národního muzea v Praze. Praha 2004.

S. Czopek: Renenansowe kafle z Będziemyśla - uwagi po 10 latach. In: J. Chovanec (ed.): Gotické a renesančné kachlice v Karpatoch. Trebišov 2005, 55-78.

D. Čaplovič: Najnovšie poznatky o stredovekom vývoji mesta a života obyvatelov Košíc. Archeologia historica 15, 1990, 87-98.

P. M. Daly: The Pelican In Her Piety. In: Emblem Scholarship. Directions and Development. Turnhout 2005, 83-108.

H. Dobrová: Košická keramika. Súpis zo zbierkových fondov Východoslovenského múzea v Košiciach. Historica Carpatica. Fondy. Košice 1988.

J. Duchoň: Relation 1603/1604. Významný prameň k dejinám Košíc. Historica Carpatica 34, 2003, 105-125.

J. Duchoň: Relation, analýza prameňa. Východoslovenský Pravek 10, 2013, 291-332.

M. Ďurišová/M. Uličný: Stredoveká keramika z Košíc. Studia archaeologica Slovaca mediaevalia 2, 1999, 193-199.

P. Fedorčák: Mesto a vojna a jezuiti. Theatrum Historiae 20, 2017, 47-64.

A. Frický: Zaniknuté sklárne v okolí Bardejova. Nové Obzory 8, 1966, 121-148.

J. Frolík/R. Kozáková/J. Musil: Jímka 938 z Chrudimi - Hradební ulice. Pokus o určení statutu jejího majitele. Archeologia Historica 43, 2018, 455-489.

J. Fröhlich: Nálezy křesacích kamenů do ručních palných zbraní z Písku a okolí. Archeologické výzkumy v jižních Čechách 31, 2018, 333-344.

J. Gasper: Vznik a úroveň sklárstva na Slovensku do roku 1700. Nové obzory 11, 1969, 137-162.

D. Gašaj: Hlavná 63/Kováčska 24 - dvor. Nálezová správa. Východoslovenské múzeum v Košiciach. Košice 2015. Unpublished.

G. Granastói: A városi élet keretei a feudális kori Magyarországon. Kassa társadalma a 16. század derekán. Budapest 2012.

A. Harčar: Historický význam protireformácie v Košiciach z roku 1604. Budapest 1942. J. Haruštiak/P. Roth/J. Vereščáková: Košice. Ostrov kultúry, otvorená zóna 2. Rekonštrukcia Východoslovenskej galérie, 2. etapa. Nálezová správa. Východoslovenské múzeum v Košiciach. Košice 2012. Unpublished.

J. Heltai: Hitviták és irodalmi élet Kassán az 1660-as évtizedben. Vieroučné polemiky a literárny život v Košiciach okolo roku 1660. In: C. Hišem/Š. Eliáš/D. Fedorová (eds.): 350. výročie Košickej univerzity. Jubilejný zborník príspevkov z medzinárodnej vedeckej konferencie, Košice 27. februára 2007. Studia Academica Historiae Ecclesiae Cassoviae 10. Košice 2007, 39-48.

M. Horvat: Keramika. Tehnologija keramike, tipologija lončenine, keramični arhiv. Ljubljana 1999.

M. Hulst/J. J. Kunicki-Goldfinger: The golden age of Amsterdam glass. A chemical and typological approach to recognize Amsterdam $17^{\text {th }}$ century glass production. In: S. Wolf/A. de Pury-Gysel (eds.): Annales du $20^{e}$ congrès de l'Association Internationale pour l'Histoire du verre. Fribourg/Romont 7-11 septembre 2015. Romont 2017, 547-553.

J. Chovanec: Palatínska kachlová pec Imricha Perényiho. In: J. Chovanec (ed.): Gotické a renesančné kachlice v Karpatoch. Trebišov 2005, 23-54, 257-259.

M. Janovčíková: Renesančné sklo. In: I. Rusina et al. (ed.): Renesancia. Umenie medzi neskorou gotikou a barokom. Bratislava 2009, 346-351.

J. Klápště (ed.): Archeologie středověkého domu v Mostě (č. p. 226). The archaeology of a medieval House (No. 226) in Most. Medievalia archaeologica 4. Praha - Most 2002. 
Kohútová 2018

Koóšová 2005

Krajic 2007

Kraskovská 1980

Krcho 1991

Kulášová/Ďurčo 2019

Lesák 2009

Madziková et al. 2015

Magdoško 2017

Marečková 1995

Mešša 2013

Mészárosová 1983

Oniszczuk 2016

Pajer 2001

Plicková 1959

Plicková 1996

Polonec/Turzová 1962

Relation 2013

Rusina 2009

Rusnák 2009

Rusnák 2014

Sedláčková 1998

Sedláčková 2007

Sedláčková et al. 2016

Scheufler 1972

Suchý 1974

Šimčík 2013

Šimončičová Koóšová 2014

Škoviera 2009
M. Kohútová: Postoj uhorského snemu k reformačným hnutiam v 16. a prvej polovici 17. storočia. In: E. Frimmová/M. Kohútová (eds.): Reformácia a jej dôsledky na Slovensku. Bratislava - Krakov - Trnava 2018, 11-22.

P. Koóšová: Kontakty medzi Talianskom a územím dnešného Slovenska v oblasti sklárskej produkcie na prelome stredoveku a novoveku. Archeologia Historica 30, 2005, 497-506.

R. Krajíc: Archaeology of the Post-Medieval period. The current state of research and research perspectives in Southern Bohemia. Studies in Post-Medieval Archaeology 2, 2007, 57-96.

L. Kraskovská: Nádoby datované nálezmi mincí na Slovensku. Zborník SNM 74. História 20, 1980, 81-106.

J. Krcho: Kassa helyrajza. Adalékok a történeti városközpont kialakulásához. Dissertation Thesis. Építészettörténeti és Elméleti Intézetet Budapesti Müszaki Egyetem. Budapest 1991. Unpublished.

E. Kulášová/M. Ďurčo: Trstenská keramika. Trstená 2019.

B. Lesák: Súbor renesančného skla z Ventúrskej ulice $3 \mathrm{v}$ Bratislave. Študijné zvesti Aú SAV 45, 2009, 23-29.

A. Madziková/V. Kandráčová/M. Kulla/Š. Nováková: Development of glassmaking and changes in its distribution in Slovakia. Folia geographica 57, 2015, 52-78.

D. Magdoško: Samospráva mesta Košice v stredoveku. Acta Historiae Cassoviensis 5. Košice 2017.

M. Marečková: Východoslovenská města a měšt’anstvo na prahu novověku. Brno 1995. M. Mešša: Drajfusy - trojnohé nádoby ako riešenie varenia a pečenia na otvorenom ohnisku a dôvody ich zániku. Zamyslenie nad drajfusmi v zbierke Rastislava Haronika z Vyšehradného. In: A. Petrakovičová (Zost.): Tradičný hrnčiarsky a kuchynský riad. Zborník z medzinárodného odborného seminára, konaného 31. augusta 2012 v Modre. Modra 2013, 14-18.

K. Mészárosová: Nález stredovekého skla v Trnave. Zborník SNM 77. História 23, 1983, 117-131.

A. Oniszczuk: Życie odbite w naczyniu konsumpcja luksusowa i codzienna w Gdańsku w XVII - XIX wieku na podstawie naczyń ceramicznych z terenu centrum dominikańskiego i kwartału Długi Targ - Powroźnicza I. Warszawa 2013.

J. Pajer: Novokřtenské fajánse ze Strachotina. Mikulov 2001.

E. Plicková: Pozdišovské hrnčiarstvo. Bratislava 1959.

E. Plicková: Krása hliny. Bratislava 1996.

A. Polonec/M. Turzová: Pukanská keramika. Martin 1962.

Relation. Správa o inšpekcii stavu mesta Košice vypracovaná v rokoch 1603-1604. Východoslovenský pravek 10, 2013, CD príloha.

I. Rusina: Spor o obrazy. In: I. Rusina et al. (ed.): Renesancia. Umenie medzi neskorou gotikou a barokom. Bratislava 2009, 71-79.

R. Rusnák: Košice v stredoveku. Na podklade archeologických výskumov. Dissertation Thesis. Archeologický ústav Slovenskej akadémie vied Nitra, VPS Košice. Košice 2009. Unpublished.

R. Rusnák: Vývoj mestskej domovej parcely na príklade Mäsiarskej 57/A v Košiciach. Slovenská archeológia 62, 2014, 315-398.

H. Sedláčková (ed.): Renesanční Olomouc v archeologických nálezech. Sklo, slavnostní keramika a kachle. Archeologické výzkumy Památkového úradu v Olomouci 1973-1996. Olomouc 1998.

H. Sedláčková: From the Gothic period to the Renaissance. Glass in Moravia 1450 - circa 1560. Studies in Post-Medieval Archaeology 2, 2007, 181-226.

H. Sedláčková/D. Rohanová/I. Charvátová/B. Tošnerová: Renaissance and $B a-$ roque glass from the central Danube region. Brno 2016.

V. Scheufler: Lidové hrnčírství v českých zemích. Praha 1972.

M. Suchý: Významné pramene k problematike stavebného vývinu východoslovenských miest zo začiatku 17. storočia. Nové obzory 16, 1974, 39-84.

P. Šimčík: Záchranný archeologický výskum na obnove objektu Kováčska č. 37 v Košiciach. Východoslovenský pravek 10, 2013, 225-229.

P. Šimončičová Koóšová: Súbor skla z Killyho kúrie v Častej. Zborník SNM 107. Archeológia 24, 2014, 221-244.

D. Škoviera: Renesančný humanizmus a mestá východného Slovenska. In: I. Rusina et al. (eds.): Renesancia. Umenie medzi neskorou gotikou a barokom. Bratislava $2009,60-70$. 
Španihel 2016

Špiesz 1972

Stajnochr 2004

Topographischer 1807

Uhorský Simplicissimus 1975

Wick 1932

Wick 1936

Žegklitz 2007
S. Španihel: Nálezy keramiky z pevnosti v Čiernom - Valoch. Zborník SNM 110. Archeológia 26, 2016, 151-161.

A. Špiesz: Remeslo na Slovensku v období existencie cechov. Bratislava 1972.

V. Štajnochr: Hrnce pro tepelné zpracování pokrmů. Studia funkcí novověké keramiky. Archeologie ve středních Cechách 8, 2004, 801-851.

Topographischer Plan der Koniglichen Frej und Haupt Stadt in Ober Ungarn ehemaligen Grenzfestung Kaschau samt ihren Vorständen. Unter Auszicht des Johan Nepom. Von Chumert Ober. Leutnants aufgenomen und gezeichnet von Anton Klimmt Ober. Feuerwehrer und Franz Kerndler Feuerwehrer des Keisr. Konigl. Bombardier Corp im Jahre 1807. KW - Heeresgeschichtliches Museum Wien, Gh/300, 1807.

Uhorský Simplicissimus. Bratislava 1975.

V. Wick: Dáta k dejinám košických dominikánov. Košice 1932.

V. Wick: Dóm sv. Alžbety v Košiciach. Košice 1936.

J. Žegklitz: Renaissance glasswork in Broumy. Studies in Post-Medieval Archaeology 2, 2007, 145-180.

\title{
Objekt 4/09 z Mäsiarskej ulice v Košiciach a jeho nálezový súbor
}

\author{
Marián Čurný - Lucia Luštíková - Rastislav Rusnák - \\ Ma roš Volovár
}

Súhrn

Dvojsezónny archeologický výskum parcely Mäsiarska 57/A v Košiciach (obr. 1) uskutočnil Archeologický ústav SAV v rokoch 2009 a 2010. Štyridsat nájdených objektov a nálezových situácií patrilo rôznorodým sídliskovým štruktúram dokladajúcim osídlenie územia od 13.-14. až po 19. storočie. Charakter objaveného osídlenia z obdobia 13.-14. storočia dáva tušit, že plocha parciel obrátených do Mäsiarskej ulice v tom čase predstavovala iba zadné dvorové trakty parciel s domami do Hlavnej ulice. Najneskôr od 15. storočia však už treba počítat's majetkovoprávnou premenou územia, spojenou so samostatným vývojom na dvoch parcelách obrátených do Mäsiarskej ulice. Ťažisko osídlenia parciel spadá do obdobia od záveru stredoveku až do konca 17. storočia, kedy pravdepodobne dochádza k opätovnej degradácii samostatnej sídelnej funkcie parciel a ich územie od 18. storočia znovu vystupuje ako spoločné s domom na Hlavnej 100 (obr. 2), čo už dokladajú i písomné a kartografické pramene.

Objekt 4/09 mal charakter jamy pravidelného kvadratického tvaru s rozmermi strán približne 200 x $150 \mathrm{~cm}$ a zaoblenými rohmi. Úroveň nájdenia mal v híbke 170-180 cm od súčasného povrchu. Dno objektu sa nachádzalo v híbke $443 \mathrm{~cm}$ od súčasného povrchu, teda $260-270 \mathrm{~cm}$ od úrovne zistenia, pričom až $140 \mathrm{~cm}$ z jeho výplne bola zahĺbená v štrkovom podloží. Na dne objektu boli v negatíve rozpoznané stopy po kolovej konštrukcii v rohoch a tiež stopy po doskovej, prípadne polgulatinovej výdreve stien medzi rohovými kolmi (obr. 3). Dá sa predpokladat', že pôvodne tak bol konštrukčne riešený celý objekt, už len kvôli stabilite kolovej konštrukcie. Kôl v juhozápadnom rohu mal štvorhranný pôdorys, zvyšné tri koly boli gulatinové. Po oboch stranách výplne v dokumentovanom profile boli objavené zvislé vrstvy piesku, ktoré pravdepodobne súvisia s vonkajšou izoláciou doskových stien objektu. Žiadne d’alšie konštrukčné prvky sa už nepodarilo nájsț. Výplň objektu tvorili vrstvy s charakteristickým prepadom stredovej časti s miernym posunom prepadu k severnej stene objektu. Kým vrchnú polovicu objektu vypíňal viac menej jednotný hnedý sypký hlinitý zásyp, v spodnej polovici bolo vrstiev viac. Sypké sivé a hnedé hlinité vrstvy striedali tenšie červeno-hnedé prepálené vrstvy a ílovito-hlinité vrstvy (obr. 4).

Objekt bol pôvodne interpretovaný ako chladnica s tým, že po zániku primárnej funkcie treba rátat̉ i s možným následným sekundárnym využitím ako odpadovej jamy. Je však potrebné uviest', že pre prvú z možností nachádzame v archeologických prameňoch len minimum opôr, výskum skôr doložil tú druhú, aj ked' tú prvú vylúčit nemožno. Artefakty materiálnej kultúry, pochádzajúce z objektu, umožňujú jeho chronologické zaradenie do obdobia raného novoveku. Popri menšej zložke, rámcovo datovanej od prelomu 15. a 16. storočia, možno prevažnú čast’ nálezov zaradit’ do druhej polovice 17. storočia. Práve v spomenutom období zaznamenalo územie skúmaných parciel najintenzívnejší samostatný vývoj, pre ktorý máme k dispozícii i najviac archeologických i archívnych prameňov. 
Nálezový súbor zo zásypu objektu 4/09 bol mimoriadne početný. Tvoria ho črepy z keramických nádob (74 prírastkových čísel) a kachlíc (7 prírastkových čísel), sklenených nádob a iných predmetov (22 prírastkových čísel), zlomky stavebnej keramiky - tehál a škridiel (6 prírastkových čísel), drobné predmety zo železa, bronzu, skla a kameňa (16 prírastkových čísel), neanalyzované rastlinné semená (3 prírastkové čísla), uhlíky (1 prírastkové číslo) a zvieracie kosti (13 prírastkových čísel).

Mimoriadne početný súbor črepov z keramických nádob naznačuje prítomnost takmer 650 keramických jedincov, pričom až v 14 \% prípadov ich bolo možné fyzicky rekonštruovat takmer úplne alebo ako väčšie torzá. Súbor keramiky pozostával zo stolovej, kuchynskej, kachliarskej a stavebnej keramiky. Medzi vysokými tvarmi boli zastúpené hrnce, hrnčeky, džbány, džbániky, fl’aše, poháre a pokladničky. Kolekcia širokých tvarov pozostávala z tanierov, mís, mís - perníc, cedidiel, šálok, panvíc - trojnožiek a pokrievok (tabela 1). Najpočetnejšie sa vyskytovali hrnce (39\%), d’alšie jedince predpokladáme v skupine nejednoznačne vyčlenených druhov nádob (hrniec/džbán, nádoba vysokého tvaru), takže konečné množstvo hrncov mohlo byṫ ešte omnoho vyššie. Najčastejšie boli vajcovitého tvaru s maximálnou vydutinou umiestnenou v hornej tretine nádoby (tab. I: 1-3, 5-8, 10-15; XVIII: 3-8; XIX: 1, 2, 5-8), no neznáme nie sú ani exempláre so súdkovitým telom a tendenciou zagulatenia (tab. I: 4; XVIII: 2), ojedinele sa vyskytujú aj kusy nevýrazne profilované (tab. I: 9; XVIII: 9), takmer valcovitého tvaru. Obyčajne majú rovné, vyskytnú sa aj mierne konkávne. Najčastejšie boli z dosky hrnčiarskeho kruhu iba stiahnuté, no významný je pomer hrncov odrezaných strunou. Ústia sú výrazne vyhnuté, modelované s prihliadnutím na vnútornú rímsu na položenie pokrievky. Zvonku boli ústia pravidelne opatrené 1-3 hlbokými žliabkami. Pri okrajoch dominovalo jednoduché zaoblenie, ale stretávame sa s viacerými spôsobmi zosilnenia, zahrotenia či zošikmenia. Uchá boli pásikové, mierne dovnútra prehnuté, posadené na okraj a rozhranie pliec a maximálnej vydutiny nádob. Neznámym nie je prečnievanie vrcholu ucha o 1-2 cm nad líniu okraja. Častým javom pri uchách je ich akési vyosenie z vertikálnej roviny. Z pohladu používatel’a nádoby, ktorý ju drží v ruke, dochádzalo v smere zdola nahor k skrúteniu ucha smerom vpravo. Hrnce zvykli byt’ glazované dvojakým spôsobom, a síce vnútro nádob bolo pokryté glazúrou redšej konzistencie a okraj bol glazovaný vrstvou kvalitne spracovanej glazúry. Farebnost’ glazúr je bežná, žltá (35\%), zelená (30\%) a hnedá (5,5\%), pričom badat’ aj určité farebné prechody medzi žltou a zelenou glazúrou v podobe zeleno-žltej škvrnitej a olivovej glazúry (9\%). Glazúry boli aplikované výhradne priamo na črep nádob bez použitia engob. Hrnce boli zdobené najmä rytím v podobe obežných línií umiestnené na rozhranie pliec a vydutiny nádob (tab. I: 1, 3, 7, 12, 14; II: 4, 10, 13; XIX: 2, 9) a iba ojedinele sa vyskytovala výzdoba malovaním červenou hlinkou (tab. II: 6; XVIII: 6). Hrnce slúžili na bočný ohrev, o čom svedčili silné stopy očadenia na strane protil’ahlej k uchu. Materiálom na výrobu hrncov bol najčastejšie (70 \%) neupravovaný íl s väčším či menším obsahom železitých častíc $\mathrm{s}$ badatel'ným podielom, zrejme prirodzene sa vyskytujúceho piesku. V rovnakom pomere sú zastúpené aj hrnce z menej železitej, jemnejšej hliny ružovohnedej, ružovočervenej farby (12 \%) a bielej hliny (11 \%). Pri hrnčekoch (5 \% zo súboru) ide o tvarový variant väčších hrncov, od ktorých sa líšia iba malými rozmermi a občas i baňatejším telom. Použitý materiál i spôsob vyhotovenia sú bez zmeny (tab. II: 1-4; III: 3, 4, 6, 8, 9; VIII: 6; XVII: 1, 4). Reprezentatívnejšími zo skupiny nádob vysokých tvarov sú džbány a džbániky $(8,4 \%$ zo súboru). Najčastejšie boli vyhotovené z bielej (65 \% pri džbánoch a 32 \% pri džbánikoch), žltkastej či ružovkastej jemnej kaolinitickej hliny, prípadne z bežnejších hrnčiarskych hlín bez piesku, avšak málo železitých, vypalujúcich sa do svetlých odtieňov hnedej, červenej a oranžovej farby (27\% pri džbánikoch). V kategórii džbánov sú zastúpené baňaté džbány s vysokým valcovitým hrdlom jednoducho vyhnutým (tab. VIII: 5, 8; IX: 9; X: 9; XI: 6, 8) alebo aj mierne profilovaným a vtiahnutým (tab. VIII: 4, 9; IX: 5, 7). Poznáme pri nich aj tvarovo identické miniatúry (tab. IX: 4, 5; X: 5, 7) alebo ide o varianty džbánov so širokým valcovitým, kónicky roztvoreným hrdlom nasadeným na gulovité telo na odsadenej nôžke (tab. IX: 6, 7, 10, 11; X: 6, 8, 11). Ďalej sú to chladiace džbány s výrazne úzkym hrdlom a hruškovitým telom, pyskovite formovaným ústím do výlevky a dutým uchom s ventilačným otvorom a sacím gombíkom (tab. VIII: 1-3; XI: 3, 4). Povrch džbánov a džbánkov býval z 2/3 pokrytý glazúrou. Pri glazúrach zaznamenávame polychrómnu výzdobu pri použití viacerých výzdobných techník (mramorovanie, trasakovanie, fŕkanie, stekanie). Z hladiska farebnosti sa vyskytuje žltá, zelená a hnedá glazúra vo viacerých odtieňoch. Nevel'ké plochy na džbánoch so širokým ústím poskytli priestor na štylizovanú výzdobu v podobe esovitých závitníc či hlbokých vlníc prevedených hlinkou zemitej farby pomocou kukučky či rožka, s vrcholmi vyplnenými striedavo touto hlinkou a zelenou glazúrou (tab. VIII: 4; IX: 6; X: 11; XI: 5). Ďalšou výzdobnou štylizáciou je obežný motív listov na pleciach a vydutine (tab. VIII: 4; XI: 5). Rovnakým postupom pomocou kukučky či rožka bol štylizovaný geometrický motív (špirály, poloblúky), aplikovaný zemitou hlinkou sfarbenou modrým farbítkom na bielej engobe pod transparentnou žltou glazúrou (tab. IX: 10, 11; X: 6). Medzi džbány patrí aj flašovitý exemplár s nízko posadenou hruškovitou vydutinou a dlhým úzkym hrdlom (tab. III: 7; XVI: 5), ktorý bol pôvodne opatrený oblúkovitým tyčinkovým uchom. K menej častým tvarom patria poháre $(0,6 \%$ zo súboru). Boli vyrobené výhradne z bielej kaolinitickej hliny a obyčajne aj celoplošne obojstranne glazované zelenou transparentnou glazúrou. Zaznamenávame pri nich jednoduchý kónický tvar (tab. IX: 3; X: 1), v niektorých prípadoch so zdôraznenou nôžkou (tab. IX: 1, 2; X: 2, 3), ku ktorej bývalo pripojené drobné tyčinkové ucho (tab. IX: 8; X: 4). Medzi pohármi sa vyskytujú aj súdkovité tvary. Poháre spolu s malými džbánikmi a pravdepodobne aj hrnčekmi slúžili na pitie pri stolovaní, no pri niektorých exemplároch nemožno vylúčit’ ani funkciu detských hračiek. Pokladničky patria medzi zvláštne tvary s nezamenitelnou funkciou. Ide o menšie gulovité, resp. cibulovité nádobky s odsadenou nôžkou a stenou prelomenou úzkou štrbinou na ukladanie mincí (tab. III: 1, 2; X: 12, 13). Ojedinelou je miniatúrna nádoba (tab. X: 10). Ide o torzo malého hrubostenného výrobku vyformovaného $\mathrm{v}$ ruke $\mathrm{z}$ bielej hliny a pokrytého transparentnou žltou glazúrou so splošteným približne gul'ovitým telom, 
zakončeným dvomi protilahlými vertikálnymi uchami. Uchá pravdepodobne slúžili na zavesenie a spodná čast’ nádoby bola zrejme iba jednoducho zaoblená. Najskôr išlo o detskú hračku. Pri širokých tvaroch sa stretávame s taniermi, resp. širokými plytkými misami s tanierovitým podokrajom (spolu 10,6 \% zo súboru). Z hladiska použitého materiálu dominuje biela hlina (28\%), no zároveň registrujeme vysoký podiel ohňa masívne poškodených nádob širokých tvarov do miery, ktorá neumožňuje ani určit’ druh použitej hliny, či zistit’ prítomnost’ glazúr a podglazúrnej výzdoby. Napriek ušlachtilej bielej hline sú misy a taniere vytočené iba povrchne, bez badatelnej snahy o úpravu povrchu. Ten je najčastejšie pokrytý transparentnou zelenou glazúrou (tab. VII: 1, 3, 4; XI: 1; XVI: 9, 10), výpravnejšia výzdoba rastlinnými a štylizovanými ornamentmi a následne celoplošne glazovaná transparentnými glazúrami zelenej alebo žltej farby je v celistvejšej podobe v súbore skôr zriedkavá (tab. VII: 2; XI: 2) vzhladom na enormný počet ohňom poškodených nádob širokého tvaru. Okrem bežných drobných tunelovitých ušiek na zavesenie pod okrajom sa vyskytli aj horizontálne tyčinkovité uchá. Ďalším príbuzným tvarom sú pokrievky (tab. I: 11; XVI: 7) jednoduchého kónického tvaru s gombíkovitým profilovaným držadlom, pričom v súbore sa vyskytli zásadne iba režné, neglazované exempláre (2,3\%). Malú čast' súboru predstavujú špecifické tvary mís - pernice (tab. V: 7) a cedidlá s husto perforovaným dnom (tab. IV: 8; XVI: 8). Šest’ exemplárov perníc bolo vytočených zo železitej piesčitej hliny hrubšej štruktúry, po vypálení tehlovočervenej farby. Ide o režné nádoby s drsným povrchom, pôvodne opatrené jedným alebo dvomi uchami, ktoré sa v rámci kuchynského riadu používali na mletie maku. Pri nálezoch fragmentov perníc z objektu 4/09 nie je vylúčené, že ide o intrúzie, dobou používania nesúčasné s väčšinovou skladbou keramických nálezov. Panvice-trojnožky (3,6 \% zo súboru) sú nehlboké misovité nádoby určené na priamy kontakt s ohňom počas vyprážania (tab. III: 5, 10, 11; XVII: 2, 3, 5). Ich zaoblené steny, pokryté z vnútornej strany takmer zásadne transparentnou žltou glazúrou, prechádzajú do približne rovného dna stojaceho na trojici nožiek. Držadlá trojnožiek sú uzavreté, ale aj otvorené na spôsob tul'ajky. Spôsob prevedenia držadiel svedčí skôr o podmienkach, potrebách a preferenciách kuchyne (dimenzie otvorených ohnísk, frekvencia a objem prípravy stravy) ako o chronologickom ukazovateli. Medzi široké tvary patria aj šálky (2,1 \% zo súboru), menšie esovite profilované sploštené nádobky s výrazným baňatým telom, ktoré použitým materiálom, hrnčiarskym prevedením a výzdobou pripomínajú hrnčeky (tab. IV: 1-6; XVI: 1-3, 6). Približne polovica z identifikovaných šálok bola režná, zvyšné mali vnútro opatrené transparentnou glazúrou najčastejšie žltej farby. Podobne ako pri hrncoch a hrnčekoch, aj šálky majú tyčinkovité uchá vyosené vpravo.

Medzi kachlicami sa vyskytli iba zlomky z komorových kachlíc, prevažne išlo o črepy z bočných stien. Pozoruhodné sú fragmenty tapetovitých riadkových a rímsových kachlíc s neúplným výzdobným motívom v režnom (tab. X: 19, 20) a polychrómne glazovanom prevedení (tab. X: 17, 18), ktoré možno zaradit do obdobia 2 . polovice 16. až začiatku 17. storočia. Kompletne zachovaná vrcholová - korunná kachlica, resp. rímsový nadstavec v podobe prelamovaného cimburia s piatimi vrcholmi zakončenými na spôsob „fleur de lis“ (tab. IX: 12; XVII: 7), má prednú stranu celoplošne glazovanú transparentnou glazúrou zelenej farby a na zadnej strane je opatrená dvoma jazykovitými výčnelkami, ktoré umožnili jej stabilizáciu na korune kachlovej pece. Tvarovo podobné nadstavce zo 16. storočia sú známe aj z ned’alekého Trebišova. Stavebnú keramiku predstavuje niekol'ko bližšie necharakterizovatelných zlomkov hranolovitých tehál a fragment spodnej časti škridly, bobrovky s oblúkovitým zakončením s hrúbkou $1,8 \mathrm{~cm}$.

Štúdium skladby keramického súboru ukázalo, že v ňom dominuje kuchynský riad. Pri týchto výrobkoch je badatelný pôvod u spoločného producenta. Nádoby sú tvarovo i výzorom niekedy takmer identické, čo naznačuje odber od miestneho výrobcu, azda člena košického hrnčiarskeho cechu, ktorý vznikol v roku 1514. V roku 1696, kedy predpokladáme, že už prebiehalo zasypávanie skúmaného objektu, sa v Košiciach spomínajú piati hrnčiari. Prevažujúce bežné utilitárne tvary kuchynskej keramiky sa ako spotrebný a zrejme nenákladný materiál opakovane nahrádzal novým i viac krát do roka, napríklad počas trhov či jarmokov. Týždenné trhy sa v Košiciach konávali pravidelne od začiatku 14. storočia vo štvrtok, zároveň to boli aj dva jarmoky, ktoré do konca stredoveku rozšírili o d’alšie tri jarmoky. Aj pri stolovej keramike ide o výrobky erudovaného hrnčiarstva, pri ktorých prekvapí, že v ponímaní dnešného archeologického bádania sú výrobky zo zdanlivo menej častých materiálov (biela kaolinitická hlina) vyhotovené skôr ležérne, čo ilustrujú najmä niektoré taniere a misy. Význam stolovej keramiky mohol byt’ pre jej majitelov, obyvatelov domácnosti, väčší a preto sa azda aj možno uvažovat, že jej funkčná rola bola dlhodobejšia. V rámci stolovej keramiky sa nepodarilo vyselektovat zložku, ktorá by sa náročnejším prevedením alebo dekorovaním vymykala z obrazu celého nálezového súboru. Bolo to spôsobené aj charakterom prostredia, v ktorom boli dané artefakty deponované (agresívne pôsobenie prostredia na povrch črepov, degradácia povrchových vrstiev glazúr a podglazúrnych výzdob). Preto sú pozoruhodné dva malé džbániky, vo farebnej schéme výzdoby ktorých sa uplatnilo modré farbítko (tab. IX: 10, 11; X: 6). Ak nešlo o importovaný cudzorodý prvok, bola by to dôležitá informácia o používaní tejto farby v regióne Košíc, t. j. v nehabánskom hrnčiarskom prostredí, ktoré modrú farbu pred začiatkom 18. storočia bežne nepoužívalo. Zasypanie objektu 4/09 a vznik hodnoteného súboru kladieme do záveru 17. storočia. Na základe vedomostí o niektorých aspektoch technológie a dekorovania keramiky však nie je vylúčené, že k tomu mohlo dôjst' aj začiatkom 18. storočia.

Z množstva fragmentov sklenených nádob sa podarilo identifikovat minimálne 33 kusov. Išlo predovšetkým o menšie čaše, poháre na stopkách (tab. VI; XV: 1-5), kanvice (tab. XII: 4; XIV: 6, 7), resp. krígle na pivo (tab. V: 7; XII: 3) a rôzne typy fliaš (tab. V: 1-4, 6, 8; XII: 1, 2; XIV: 3, 4; XV: 6-8). Jednou z nich je štvorhranná flaša s celoplošnou emailovou mal'bou, v rámci ktorej zaujme motív pelikána drásajúceho si zobákom hrud', aby krvou nasýtil svoje tri mlád’atá, natahujúce sa k nemu z hniezda (tab. XII: 6; XIII). Výrazná je i svadobná holba s emailovým mal’ovaným 
figurálnym motívom mladomanželov a s vročením 1649 (tab. XII: 5; XIV: 1, 2). Skladbu sklenených výrobkov dopíňa tabulové sklo - okenné terčíky s priemerom $10 \mathrm{~cm}$ (tab. IX: 13, 14). Súbor skla z objektu z vel'kej časti pochádza z domácich uhorských sklární, ktoré nedokážeme identifikovat, preto pri absencii písomných správ možno iba uvažovat’ o niektorých zo známych hút na východnom Slovensku (Medzev, Bardejovská Nová Ves, lubovnianske panstvo a iné). Obzvlášt zretel’né to je v prípade pohárov na nôžke a viacerých druhov fliaš. Naopak pozoruhodné sú exempláre malované emailom, pri ktorých predpokladáme cudzí pôvod. Na základe početnejších analogických nálezových súborov z rozličných sociálnych prostredí je oprávnená domnienka, že podstatná čast’ sklenených nádob z Mäsiarskej ulice 57/A v Košiciach patrila k domácemu výrobnému sortimentu (poháre, flaše), ktorý v priebehu 17. storočia už bol relatívne bežne zastúpený v uhorských domácnostiach. Nálezový súbor z objektu 4/09 dopíňali i dve mince, no stav ich zachovania už neumožnil ich identifikovat', či d’alšie predmety z kovu a iné drobné predmety, napríklad kresací kameň (tab. XVII: 6).

Parcely na dnešnej Mäsiarskej 57/A boli v období včasného novoveku súčastou vnútorného mesta, no v rámci neho šlo skôr o perifériu, resp. o čast̉ mesta, kde možno predpokladat nižšiu sídelnú atraktivitu. Archeologickým výskumom v rokoch 2009-2010 sa preskúmalo 40 zahĺbených objektov a situácií, ktoré boli publikované (Rusnák 2014). Objekty 4/09 a 5/09 spolu s predpokladaným meštianskym domom a zemnými objektmi 7/09 a 8/09 reprezentujú osídlenie parcely od 15. po koniec 17. storočia (obr. 5). Výrazne zahĺbený objekt 4/09 s pravidelným kvadratickým pôdorysom a drevenou kolovou konštrukciou v rohoch a výdrevou stien možno interpretovat’ ako odpadovú jamu, prípadne žumpu. Jeho výplň poskytla najmä kolekciu keramiky a skla, ktorá nám pomáha utvárat’ obraz o košickej meštianskej societe včasného novoveku s taažiskom v druhej polovici 17. storočia. Čast’ nálezového súboru možno datovat' ešte do obdobia záveru stredoveku až raného novoveku. Nemožno teda vylúčit, že objekt odpadovej jamy pochádza už z prelomu 15. a 16. storočia a slúžil dlhodobo, s pravidelným čistením. V určitom nesúlade s takouto možnostou však je, že chronologicky najstaršej zložke nálezového súboru nezodpovedá stratigrafická situácia zachytená v objekte. Nemožno konštatovat, že by napríklad najspodnejšie vrstvy objektu obsahovali iba najstarší horizont nálezov. Nálezy najstaršieho horizontu boli skôr roztrúsené v rámci výplne a navyše boli značne fragmentárne, čo je v kontraste s často celými kusmi keramiky z obdobia 17. storočia. To indikuje bud' predchádzajúcu manipuláciu so zásypom objektu, ale črepy sa do výplne mohli dostat' i pri postupnom alebo záverečnom zasypávaní objektu. Zaujímavá je i najmladšia, už viac menej baroková zložka nálezov, ktorá vykazuje vyššiu mieru zasiahnutia ohňom a naznačuje, že k zániku osídlenia na parcelách na prelome 17. a 18. storočia mohlo dôjst’ po požiari. Charakter nálezového súboru naznačuje, že išlo skôr o skromnú meštiansku domácnost'. Pre obdobie 15. a 16. storočia osídlenie na skúmaných parcelách dokladajú najmä archeologické pramene, chýbajú údaje v dobových písomnostiach. Plastickejší obraz života na oboch parcelách poznáme až zo 17. storočia. Severnú parcelu obývala v priebehu 17. storočia rodina Vadasovcov a približne od tretiny storočia rodina Süvegosovcov. Južná parcela striedala počas 17. storočia majitel’ov častejšie. V prvej polovici poznáme mená Gergal Madir a Peter Csontos. Pre tretiu štvrtinu storočia sú to Hans Czibner a David Rudell a pre poslednú štvrtinu Győrgy Szabo Tyhani, Janos Kovacs, či Palne Varga. Aj ked’ znenie mien nie je dostatočnou oporou pre snahu o určenie národnosti majitelov, možno konštatovat', že s výnimkou mien Czibner a Rudell prevažujú najmä mad’arsky znejúce mená a že práve táto národnost̉ majitelov meštianskej domácnosti sa zdá najviac pravdepodobná. O ich vierovyznaní toho vieme ešte menej. Velmi opatrný príklon ku katolicizmu má iba nepevnú oporu vo vyobrazení pelikána kŕmiaceho svoje mlád’atá na jednom zo získaných sklenených artefaktov. Indíciu smerujúcu k úvahám o povolaní majitelov sa v nálezovom fonde nepodarilo získat'.

Obr. 1. Košice. Severozápadná čast’ Starého mesta s vyznačením hraníc skúmaného územia na Mäsiarskej 57/A (čiernou) a parciel na Hlavnej 98 a Hlavnej 100.

Obr. 2. Výsek z plánu mesta z roku 1807, kde skúmané územie už tvorí záhradu domu s číselným označením 140

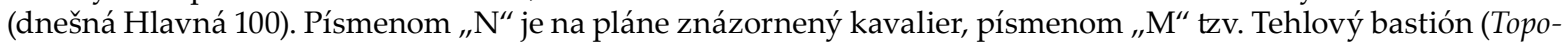
graphischer 1807).

Obr. 3. Košice, Mäsiarska 57/A. Výskum obj. 4/09. Stopy po kolovej konštrukcii v rohoch objektu a po výdreve stien medzi rohovými kolmi na dne objektu. Foto R. Rusnák.

Obr. 4. Košice, Mäsiarska 57/A. Stratigrafia zásypu obj. 4/09. Legenda: 1 - štrk (podložie); 2 - žltý íl; 3 - sivý íl; 4 - piesok (izolácia); 5 - sivá ílovitá; 6 - červenohnedá, prepálená, sypká; 7 - sivá, sypká, vel’a nálezov; 8 - sypká hnedá s črepmi; 9 - tmavosivá prepálená; 10 - žltý íl; 11 - hnedá hlinitá; 11a - sivý íl, mazlavá; 12 - hlinitá s kamienkami; 13 - okruhliaková dlažba; 14 - hlinitá s črepmi a kameňmi (premiešaná, no kompaktná); 15 - hlinito ílovitá s kamienkami; 16 - kamenný obj. 3/09; K - kameň. Sivou farbou - výplň obj. 4/09. Kresba L. Luštíková.

Obr. 5. Košice, Mäsiarska 57/A. Skúmaná parcela s objektmi z obdobia neskorého stredoveku až včasného novoveku. Legenda: a - línia pravdepodobnej hranice južnej a severnej parcely. Autor R. Rusnák.

Tab. I. Košice-Mäsiarska 57/A. Hrnce. Kresba M. Volovár.

Tab. II. Košice-Mäsiarska 57/A. Hrnce a hrnčeky. Kresba M. Volovár.

Tab. III. Košice-Mäsiarska 57/A. Hrnčeky, panvice trojnožky, džbán, pokladničky. Kresba M. Volovár.

Tab. IV. Košice-Mäsiarska 57/A. Šálky, misy, cedidlo. Kresba M. Volovár.

Tab. V. Košice-Mäsiarska 57/A. Fl’aše, fl’aštičky, karafa, pohár - sklo. Kresba M. Volovár.

Tab. VI. Košice-Mäsiarska 57/A. Poháre na nôžke (čaše) - sklo. Kresba M. Volovár.

Tab. VII. Košice-Mäsiarska 57/A. Misy. Kresba M. Volovár. Farebnost:: a - zelená; b - žltohnedá; c - tmavočervená. 
Tab. VIII. Košice-Mäsiarska 57/A. Krčahy, džbány, hrnčeky. Kresba M. Volovár. Farebnosṫ: a - zelená; b - tmavozelená; c, d - žltohnedá; e, f - žltá; g - tmavočervená; h - hnedá.

Tab. IX. Košice-Mäsiarska 57/A. Poháre, džbániky, džbány, kachlica. Sklenené okenné výplne. Kresba M. Volovár. Mierka: $\mathrm{a}-1-12 ; \mathrm{b}-13,14$. Farebnost': $\mathrm{a}$ - zelená; $\mathrm{b}$ - žltohnedá; $\mathrm{c}$ - hnedá; $\mathrm{d}$ - žltá; $\mathrm{e}$ - modrá; f - tmavočervená.

Tab. X. Košice-Mäsiarska 57/A. Poháre, džbániky, pokladničky, miniatúrna nádoba, kachlice. Foto M. Čurný (10, 15-20), R. Rusnák (1-9, 11-14). Mierka: a -1-13; b-14-20.

Tab. XI. Košice-Mäsiarska 57/A. Misy, džbány. Foto R. Rusnák. Mierka: a - 1, 2, 5-8; b - 3, 4.

Tab. XII. Košice-Mäsiarska 57/A. Sklenené nádoby: flaše, kanvice, holba. Foto R. Rusnák.

Mierka: $a-1,4 ; b-2,3,5,6$.

Tab. XIII. Košice-Mäsiarska 57/A. Mal’ovaná flaša - sklo. Kresba M. Volovár.

Tab. XIV. Košice-Mäsiarska 57/A. Flaše, kanvice, holba - sklo. Kresba M. Volovár. Mierka: a -1-4; b-5-7.

Tab. XV. Košice-Mäsiarska 57/A. Poháre na nôžke, flaše - sklo. Foto R. Rusnák. Mierka: a -1-5, 7, 8; b - 6.

Tab. XVI. Košice-Mäsiarska 57/A. Šálky, džbán, misy, cedidlo, pokrievka. Foto R. Rusnák. Mierka: a - 1-8; b - 9, 10.

Tab. XVII. Košice-Mäsiarska 57/A. Hrnčeky, panvice - trojnožky, kachlica, kresací kameň. Foto R. Rusnák. Mierka: $\mathrm{a}-1-5 ; \mathrm{b}-6,7$.

Tab. XVIII. Košice-Mäsiarska 57/A. Hrnce. Foto R. Rusnák.

Tab. XIX. Košice-Mäsiarska 57/A. Hrnce. Foto R. Rusnák.

Tabela 1. Košice-Mäsiarska 57/A. Štatistika keramického súboru. Legenda: A - druh nádoby (1 - cedidlo, 2 - džbán, 3 - džbánik, 4 - džbánik/pohár, 5 - flaša, 6 - hrniec, 7 - hrniec/džbán, 8 - hrnček, 9 - miniatúrna nádoba, 10 - misa, 11 - misa - pernica, 12 - nádoba vysokého tvaru, 13 - panvica - trojnožka, 14 - pohár, 15 - pokladnička, 16 - pokrievka, 17 - šálka, 18 - tanier, 19 - tanier/misa); B - počet identifikovaných keramických jedincov; C - počet keramických zlomkov; D - hrnčiarska hlina (D1 - biela hlina, D2 - ružovočervená, ružovohnedá jemná hlina, D3 - ružovobiela jemná hlina, D4 - žltobiela jemná hlina, D5 - žltá, ružová, červená slinutá hlina, D6 - železitá hlina, hnedá, červená, oranžová, D7 - neurčitelná kvôli poškodeniu - prepálenie); E - glazúra (E1 - transparentná zelená glazúra, E2 - transparentná žltá glazúra, E3 - transparentná hnedá glazúra, E4 - kombinácia transparentnej zelenej a žltej glazúry, E5 - transparentná zelenožltá glazúra, E6 - transparentná žltohnedá glazúra, E7 - neurčitel'ná kvôli poškodeniu - prepálenie); F - engoba.

Translated by Gavin Cowper

Mgr. Marián Čurný, PhD.

Zemplínske múzeum v Michalovciach

Kostolné námestie 1

SK - 07101 Michalovce

marian.curny@gmail.com

Mgr. Rastislav Rusnák, PhD.

Katedra teórie a dejín umenia

Fakulta umení Technickej univerzity v Košiciach

Watsonova 4

SK - 04200 Košice

rastislav.rusnak@hotmail.sk
Mgr. Lucia Luštíková, PhD.

Archeologický ústav SAV-OVVS Košice

Hrnčiarska 13

SK -040 01 Košice

lustikova@saske.sk

Mgr. Maroš Volovár

Ústav teorie a dějin architektury

Fakulta architektury ČVUT v Praze

Thákurova 9

CZ -160 00 Praha

maros.volovar@fa.cvut.cz 